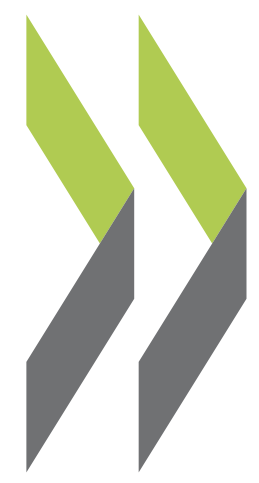

OECD Economics Department Working Papers No. 1324

Raising Korea's productivity through innovation and structural reform

Randall S. Jones,

Jae Wan Lee 
Organisation de Coopération et de Développement Économiques

Organisation for Economic Co-operation and Development

29-Sep-2016

ECONOMICS DEPARTMENT

English - Or. English

\section{RAISING KOREA'S PRODUCTIVITY THROUGH INNOVATION AND STRUCTURAL REFORM}

ECONOMICS DEPARTMENT WORKING PAPERS No. 1324

By Randall S. Jones and Jae Wan Lee

OECD Working Papers should not be reported as representing the official views of the OECD or of its member countries. The opinions expressed and arguments employed are those of the authors.

Authorised for publication by Robert Ford, Deputy Director, Country Studies Branch, Economics Department.

All Economics Department Working Papers are available at www.oecd.org/eco/workingpapers

JT03401646

Complete document available on OLIS in its original format

This document and any map included herein are without prejudice to the status of or sovereignty over any territory, to the delimitation of

international frontiers and boundaries and to the name of any territory, city or area. 
OECD Working Papers should not be reported as representing the official views of the OECD or of its member countries. The opinions expressed and arguments employed are those of the author(s).

Working Papers describe preliminary results or research in progress by the author(s) and are published to stimulate discussion on a broad range of issues on which the OECD works.

Comments on Working Papers are welcomed, and may be sent to the Economics Department, OECD, 2 rue André-Pascal, 75775 Paris Cedex 16, France, or by e-mail to econ.contact@ oecd.org.

All Economics Department Working Papers are available at www.oecd.org/eco/workingpapers.

This document and any map included herein are without prejudice to the status of or sovereignty over any territory, to the delimitation of international frontiers and boundaries and to the name of any territory, city or area.

The statistical data for Israel are supplied by and under the responsibility of the relevant Israeli authorities. The use of such data by the OECD is without prejudice to the status of the Golan Heights, East Jerusalem and Israeli settlements in the West Bank under the terms of international law.

Latvia was not an OECD member at the time of preparation of this publication. Accordingly, Latvia does not appear in the list of OECD Members and is not included in the zone aggregates.

\section{(C) OECD (2016)}

You can copy, download or print OECD content for your own use, and you can include excerpts from OECD publications, databases and multimedia products in your own documents, presentations, blogs, websites and teaching materials, provided that suitable acknowledgment of OECD as source and copyright owner is given. All requests for commercial use and translation rights should be submitted to rights@oecd.org 


\section{ABSTRACT/RÉSUMÉ \\ Raising Korea's productivity through innovation and structural reform}

Raising productivity requires addressing a wide range of policies that affect resource allocation, the creation and diffusion of technology, human capital and the creation and financing of start-ups. The greatest gains can be achieved in the service sector and in SMEs, where productivity has fallen to less than a third of large firms. Regulatory reform, increased international openness and labour flexibility would support such reallocation and technology diffusion. Korea's large investment in R\&D and education should be leveraged to raise productivity by enhancing university and public research and strengthening its links with the business sector and global innovation networks. To take advantage of innovation, the relatively low skill levels of workers above age 35 calls for increased lifelong learning. Perhaps most important, it is essential to shift SME policies away from promoting the survival of firms and towards productivity gains. Given market failures in indirect financing, developing capital markets, including venture capital investment, is a priority to boost firm creation.

This Working Paper relates to the 2016 OECD Economic Survey of Korea (http://www.oecd.org/eco/surveys/economic-survey-korea.htm)

JEL classification: L5, L26, M13 O3, O53.

Keywords: productivity; regulatory reform; innovation; creative economy; SMEs.

**********************************

\section{Augmenter la productivité de la Corée à travers l'innovation et la réforme structurelle}

Un large éventail de politiques touchant l'allocation des ressources, la création et la diffusion de la technologie, le capital humain et la création et le financement des nouvelles entreprises s'imposent pour faire stimuler la productivité. Les gains les plus importants peuvent être atteints dans le secteur des services et dans les PME, où la productivité est tombée à moins d'un tiers de celle des grandes entreprises. La réforme réglementaire, une plus grande ouverture internationale et la flexibilité du travail soutiendraient cette réaffectation et la diffusion des technologies. L'investissement considérable de la Corée en R-D et dans l'éducation devrait être mis à profit pour augmenter la productivité en améliorant la recherche à l'université et dans le secteur public et en renforçant ses liens avec le secteur des entreprises et des réseaux mondiaux d'innovation. Pour tirer parti de l'innovation, il faut renforcer la formation continue pour pallier aux niveaux relativement faibles de compétences des travailleurs ayant dépassé l'âge de 35 ans. Peut-être plus crucialement, il est essentiel de changer les politiques visant les PME en abandonnant progressivement la promotion de leur survie et en mettant l'accent sur les gains de productivité. Étant donné les défaillances du marché en matière de financement indirect, le développement des marchés de capitaux, y compris les investissements de capital-risque, est une priorité pour stimuler la création d'entreprises.

Ce Document de travail a trait à l'Étude économique de l'OCDE de la Corée, 2016 (http://www.oecd.org/fr/eco/etudes/etude-economique-coree.htm).

Classification JEL : L5, L26, M13 O3, O53.

Mots clés : productivité, réforme réglementaire, innovation, économie créative, PME. 


\section{TABLE OF CONTENTS}

\section{RAISING KOREA'S PRODUCTIVITY THROUGH INNOVATION AND STRUCTURAL REFORM ...6}

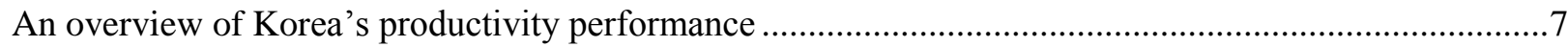

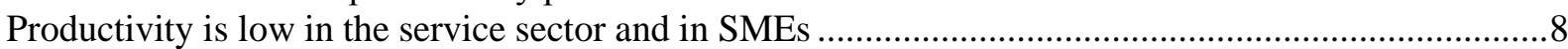

Appropriate framework conditions are needed to increase productivity ................................................11

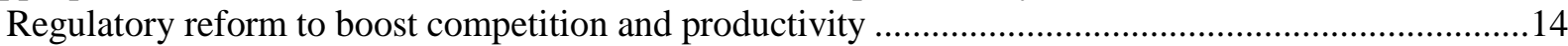

Regulations are realtively stringent, especially in the service and SME sectors ...............................14

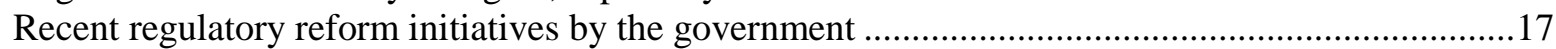

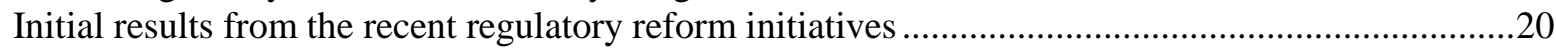

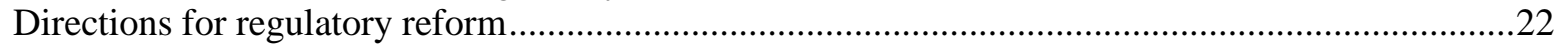

Other aspects of framework conditions to promote productivity growth.............................................23

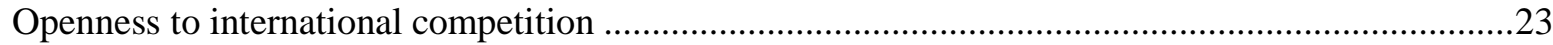

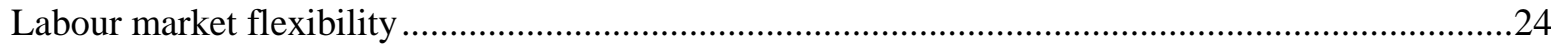

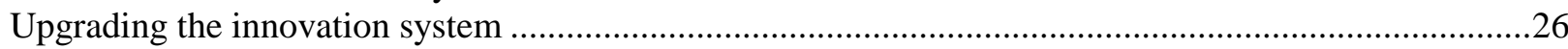

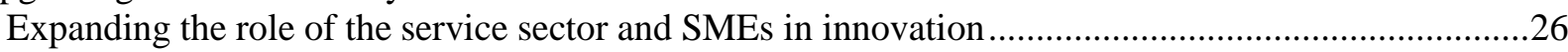

Improving the quality of universities and government research institutes (GRIs) ..............................27

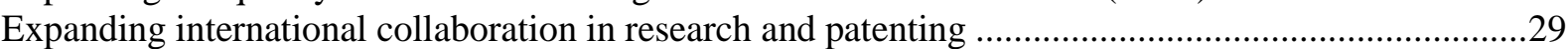

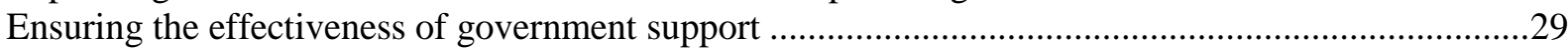

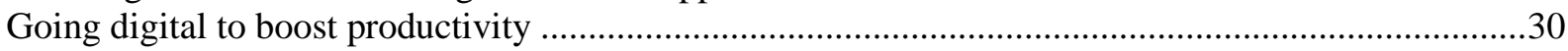

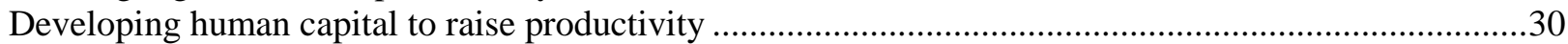

Policies to promote SMEs' productivity through innovation ..................................................................32

SME policies promote the survival of low-productivity small firms ...................................................33

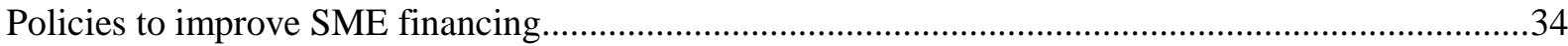

The government role is expanding, while problems remain in private-sector lending .......................34

Developing venture capital and other forms of capital-market financing .............................................39

Korea's creative economy initiative emphasises the role of venture capital.........................................40

Making venture capital investment a driver of innovation ....................................................................41

Increasing the focus on start-ups and firms at an early stage of development...................................41

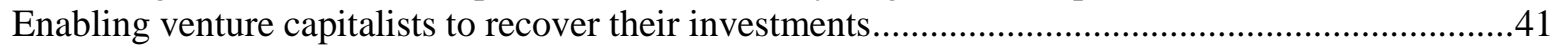

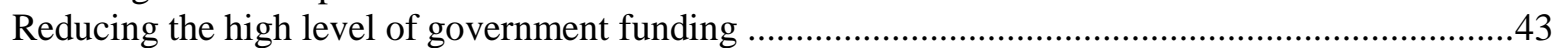

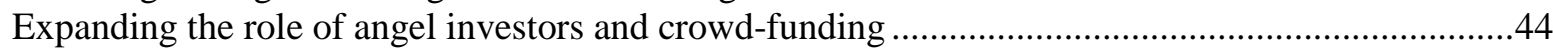

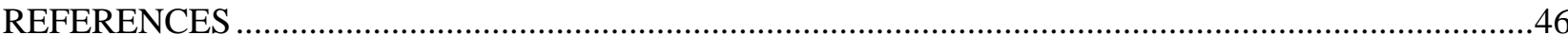

\section{Tables}

Table 1. A comparison of SMEs and large firms in Korea in 2010 .......................................................11

Table 2. There are a large number of economic regulations on SMEs .................................................17

Table 3. Economic regulations on SMEs by type of activity .............................................................18

Table 4. Policy goals for the expansion of promising service industries ...............................................20

Table 5. The service sector accounts for less than one-third of regulations that have been examined......21

Table 6. The number of negative-list regulations on business activity has increased .............................22

Table 7. Service firms are less active in R\&D and innovation than those in the manufacturing sector ....26

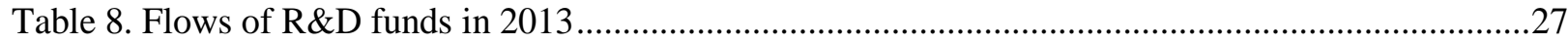

Table 9. Creative destruction in Korea's manufacturing and mining sectors...........................................33

Table 10. SME reliance on government financing has increased since 2009 .........................................34

Table 11. Basic policy direction to build a new guarantee system for SMEs...........................................36 
Table 12. Lending to SMEs is increasingly backed by collateral and concentrated among highly-rated

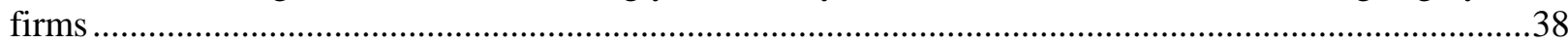

Table 13. The SMEs' share of financing through stocks and bonds has fallen sharply............................39

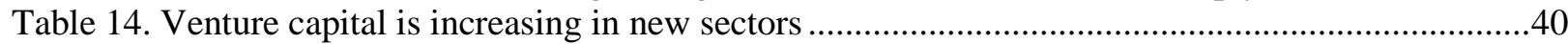

Table 15. The role of capital markets for each stage of the business life cycle .......................................42

\section{Figures}

Figure 1. Korea's labour productivity growth has been the fastest in the OECD despite a recent

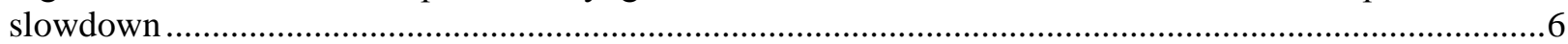

Figure 2. Korea's labour productivity remains far below the top half of OECD countries .......................8

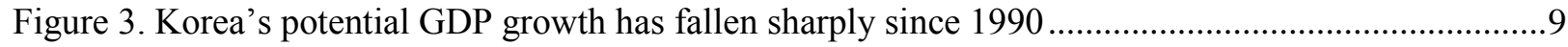

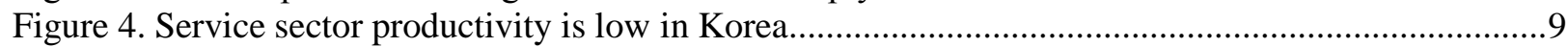

Figure 5. Total factor productivity growth in Korea's service sector has been negative ...........................10

Figure 6. The service sector has a low capital stock and its links to manufacturing are weak .................10

Figure 7. Korea has a wide labour productivity gap between SMEs and large firms ...............................12

Figure 8. Entry and exit rates have fallen in both the manufacturing and service sectors .......................13

Figure 9. Productivity growth in service industries varies widely ......................................................... 14

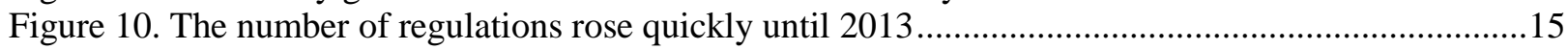

Figure 11 . Korea's product market regulations are relatively stringent.................................................16

Figure 12. Korea's barriers to trade and investment are the second highest in the OECD .......................24

Figure 13. Korea's service trade restrictiveness is relatively high in some sectors OECD ....................25

Figure 14. An overview of Korea's national science and innovation system ......................................28

Figure 15. The use of cloud computing services is low in Korea ........................................................... 31

Figure 16. Skills of older workers in Korea are well below the OECD average ....................................32

Figure 17. Entrepreneurship education is needed in Korea to improve the image and skills of

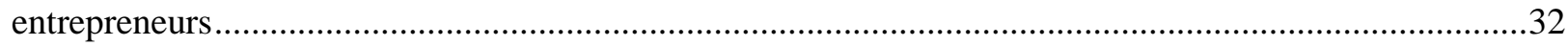

Figure 18. Public financing for SMEs is high compared to other major advanced countries....................35

Figure 19. The number of non-viable companies is increasing ..............................................................37

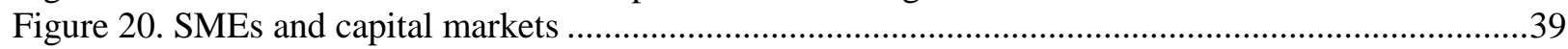

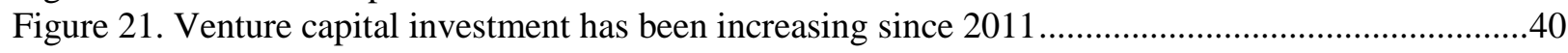

Figure 22. Venture capital investment is overly focused on mature firms ..............................................41

Figure 23. Comparison of the development of KONEX and AIM ....................................................43

Figure 24. The amount of investment by business angels collapsed following the bursting of the IT

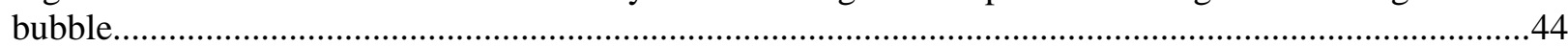

\section{Boxes}

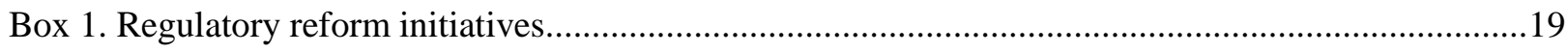

Box 2. Current government's policy direction for regulatory reform in the service industry ...................20

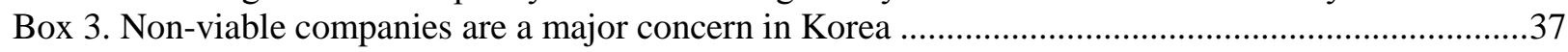

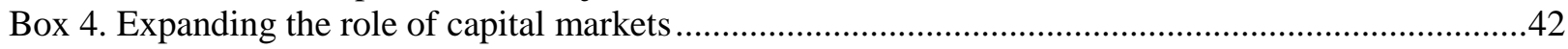

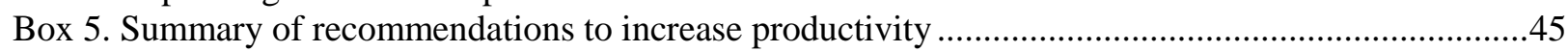




\title{
RAISING KOREA'S PRODUCTIVITY THROUGH INNOVATION AND STRUCTURAL REFORM
}

\author{
By Randall S. Jones and Jae Wan Lee
}

Productivity growth in Korea during the past 25 years has been the fastest in the OECD area (Figure 1), helping to lift per capita income from 39\% of the average of the top half of OECD countries in

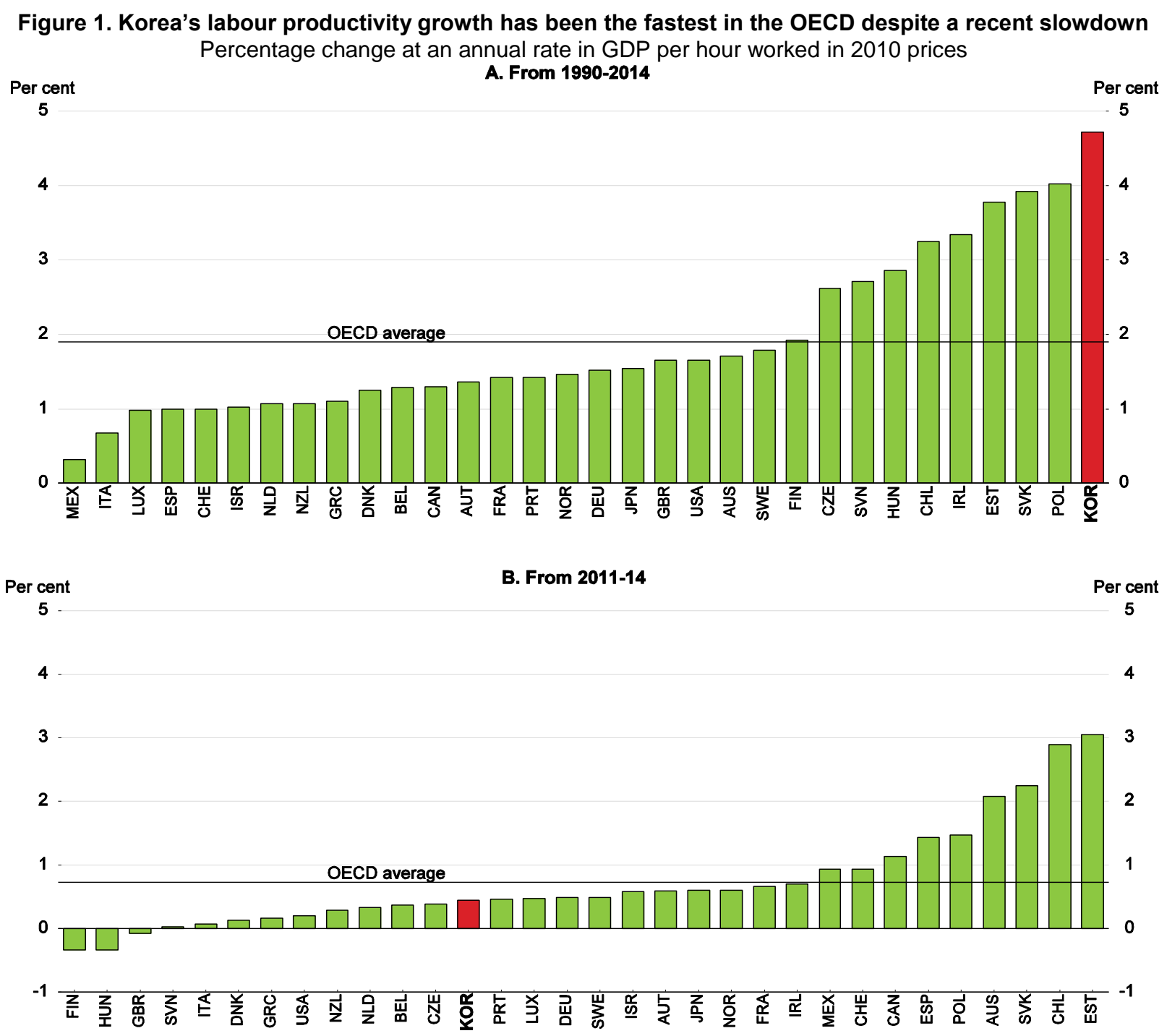

Source: OECD Productivity Database (http://www.oecd.org/std/productivity-stats/).

1. Randall S. Jones is head of the Japan/Korea Desk in the Economics Department of the OECD and Jae Wan Lee is an economist on that Desk. The authors would like to thank OECD colleagues (Kris Boschmans, Centre for Entrepreneurship, SMEs and Local Development; Maria Borga, Directorate for Financial and Enterprise Affairs; Robert Ford, Kohei Fukawa, Yong-Seong Kim, Vincent Koen, Alvaro Pereira, all from the Economics Department; Dirk Pilat, Science, Technology and Innovation Directorate; and Shane Samuelson, Education Directorate) and officials from the Korean government, for valuable comments on earlier drafts. Special thanks go to Lutécia Daniel for technical assistance and to Mercedes Burgos for technical preparation. 
1991 to $75 \%$ by 2014 . However, in recent years, Korea has been facing strong competition in global markets with emerging economies, notably China. Meanwhile, high household debt, stagnant service sector productivity and struggling SMEs have constrained domestic demand. Output growth slowed from a 41/4 per cent annual pace over 2001-11 to 23/4 per cent since 2011, in the context of a deceleration of world trade growth. Productivity growth fell below the OECD average over 2011-14 (Panel B).

Korea needs sustained growth to achieve convergence to the highest-income countries and to cope with rapid population ageing and the potential cost of economic rapprochement with North Korea. However, labour inputs will fall significantly due to population ageing, which is projected to be the fastest in the OECD. Indeed, Korea's population, currently the fourth youngest in the OECD, is projected to be the third oldest by 2050 . The working-age population will peak in 2016, implying a sharp decline in the number of workers supporting those in retirement. Policies to reduce obstacles to the employment of women, youth and older persons would slow the decline in the labour force (see 2016 OECD Economic Survey of Korea). Even with a rise in labour participation, productivity remains the ultimate growth engine for Korea. Recognising the weaknesses of Korea's traditional growth model, the government launched an initiative in 2013 to foster a "creative economy" centred on innovation, in which start-ups and high-growth small businesses play a key role. In early 2016, the government announced a plan to inject 80 trillion KRW (5\% of GDP) of public funds to nurture new growth engines, including smart cars. The President stated that the government has to support promising sectors, including cultural content, bio health, tourism and information technology.

This paper focuses on policies to raise productivity, emphasising the importance of narrowing the productivity gaps between manufacturing and services and between large and small firms. After an overview of Korea's productivity performance, the following section considers framework conditions to promote technology diffusion and resource reallocation, particularly through regulatory reform. The third section examines the innovation system and how it could contribute more to productivity growth and is followed by a discussion of human capital. The fifth section discusses policies related to SMEs. Venture capital investment, a key to the creation and growth of innovative firms, is examined in the final section. Policy recommendations are summarised at the end of this paper.

\section{An overview of Korea's productivity performance}

Labour productivity in Korea has increased at an annual average pace of $4.7 \%$ since 1990, compared to an OECD average of $1.9 \%$ (Figure 1). Moreover, total factor productivity (TFP) growth, which measures the growth of GDP above the combined contributions of total hours, workforce skills, machinery and structures and ICT capital, has contributed an average of 13/4 percentage points to GDP growth per year since 1990, compared to $1 / 2$ percentage point in the United States. Rapid productivity growth reflected Korea's large scope for convergence to high-income countries. Similarly, productivity growth has slowed as Korea moved toward the global knowledge frontier. Nevertheless, the deceleration since 2011, while Korea's labour productivity per hour worked still ranks near the bottom among OECD countries (Figure 2), is worrisome, particularly as Korea's labour inputs (Panel B) are expected to shrink.

The OECD estimates that Korea's potential growth rate has slowed from over $9 \%$ in the early 1990 s to around 31/4 per cent, matching the Bank of Korea's current estimate (Figure 3). The decline is due to two factors; $i$ ) the contribution of labour inputs fell as the growth of the working-age population decelerated and working hours declined; and ii) trend labour productivity has fallen from around $6 \%$ to a little more than $2 \%$, reflecting in part Korea's convergence toward high-income countries. 
Figure 2. Korea's labour productivity remains far below the top half of OECD countries

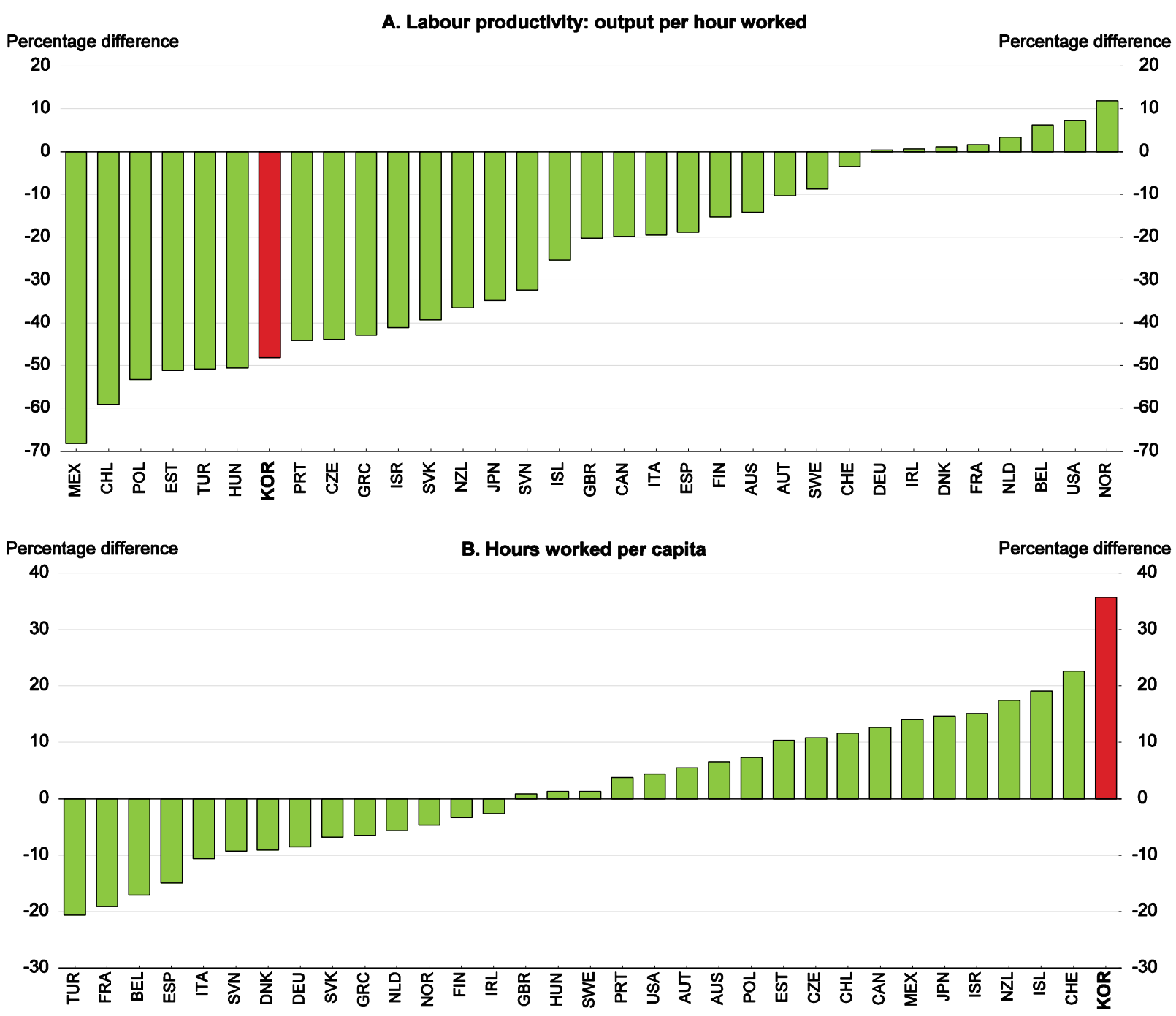

Note: Each country's performance relative to the top 17 OECD countries in 2014 using 2010 PPP exchange rates. Luxembourg, where labour productivity is $62 \%$ above the top 17 OECD countries and hours worked are $2 \%$ below, is not shown in the figure.

Source: OECD Going for Growth Database (http://www.oecd-ilibrary.org/economics/economic-policy-reforms-2016 growth-2016-en).

\section{Productivity is low in the service sector and in SMEs}

The gap in the productivity level between Korea and the top half of OECD countries (Figure 2) is largely explained by low labour productivity in services, which was $45 \%$ of that in manufacturing in 2014, compared to an average of $90 \%$ in the OECD (Figure 4). Services accounted for 59.2\% of Korean GDP, well below the OECD average, as export-led development has siphoned capital, talent and other resources away from services and toward manufacturing (Jones, 2009). This has contributed to weak TFP growth in services. Indeed, TFP made a negative 1.0 percentage-point contribution to service-sector growth over 2001-09, compared to a positive contribution of 1.7 points in manufacturing (Figure 5). In the United States, Germany and the United Kingdom, TFP made a positive contribution to both sectors. Low service productivity relative to manufacturing is due in part to weaker competitive pressures and relatively stringent regulations, resulting in a less efficient use of resources (OECD, 2015f). In addition, R\&D investment is lower in services than in manufacturing. These factors are discussed below. 
Figure 3. Korea's potential GDP growth has fallen sharply since 1990

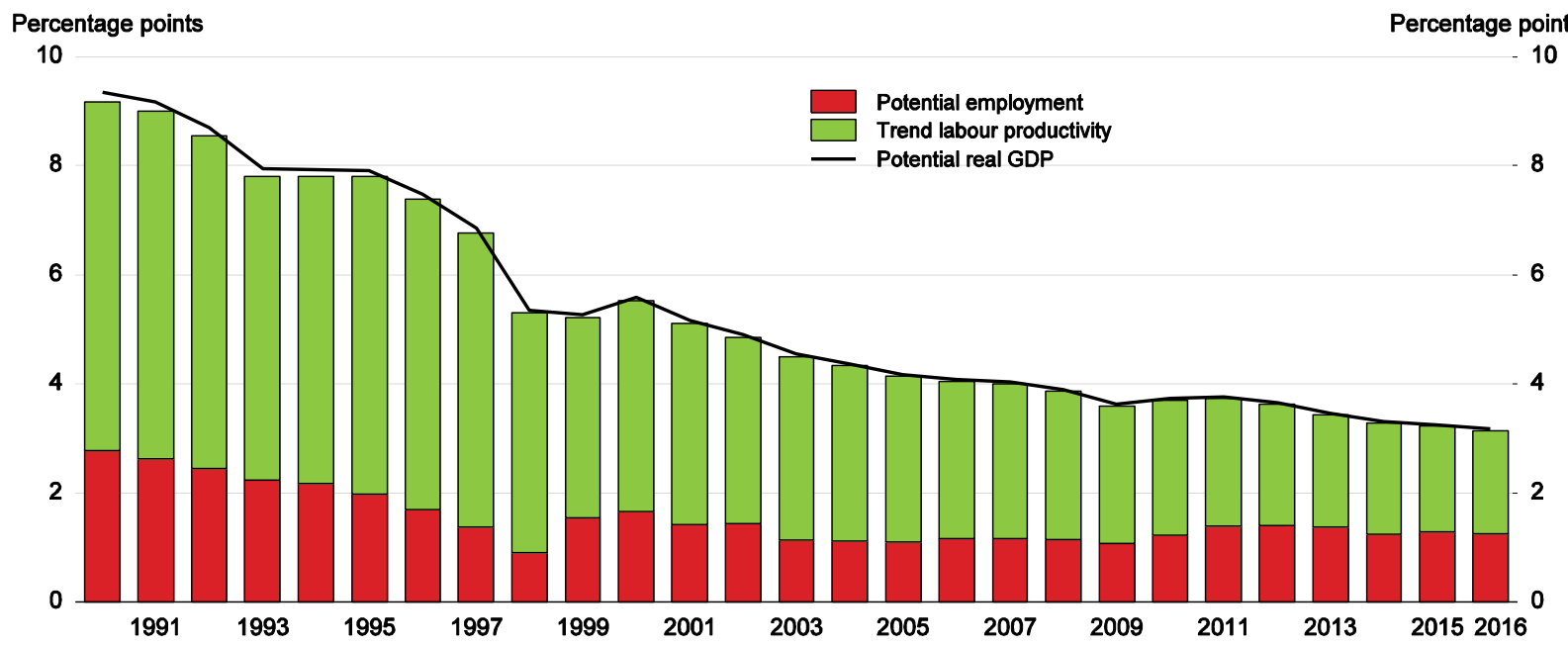

Source: OECD Economic Outlook 99 Database (http://stats.oecd.org/index.aspx?DataSetCode=EO).

Service productivity is also weakened by a few special factors specific to Korea. First, the service sector has low capital intensity: capital stock per employee was well below the most advanced economies (Figure 6, Panel A), thereby holding back productivity (Baek and Joo, 2014a). Second, the links between services and other sectors are weak. The share of services as intermediate goods in all industries was only 16\% in Korea in 2011 compared to around 26\% in the United States and Germany (Panel B). Their share as intermediate inputs for manufacturing in Korea was particularly low. Moreover, domestic services accounted for only $25 \%$ of Korea's value-added in exports, the third-lowest share in the OECD (OECD, 2015a). This may partially reflect the fact that the vertically-integrated conglomerates that account for a large share of exports tend to perform services in-house rather than contracting out. Korea also exports fewer services compared to other OECD countries. The service industry's share in Korea's exports in 2012 was only $2.5 \%$ compared to $14.5 \%$ in the United States and $3.3 \%$ in Japan.

Figure 4. Service sector productivity is low in Korea

Value added in 2014 based on 2010 prices
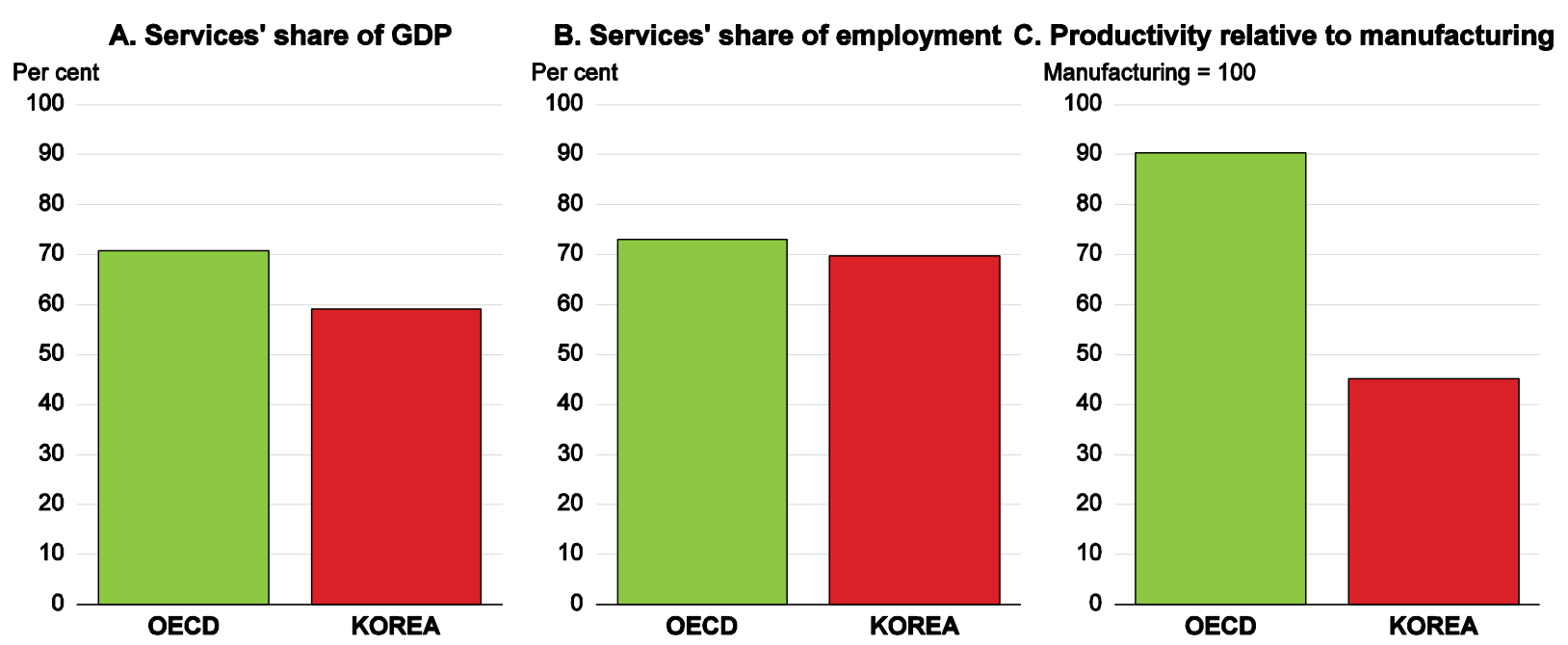

Source: OECD National Accounts Database (http://www.oecd-ilibrary.org/economics/data/oecd-national-accounts-statistics na-dataen); OECD STI Database (http://www.oecd-ilibrary.org/science-and-technology/data/oecd-science-technology-and-r-d-statistics strddata-en) 
Figure 5. Total factor productivity growth in Korea's service sector has been negative Contribution to value-added growth in percentage points in the $2000 \mathrm{~s}^{1}$
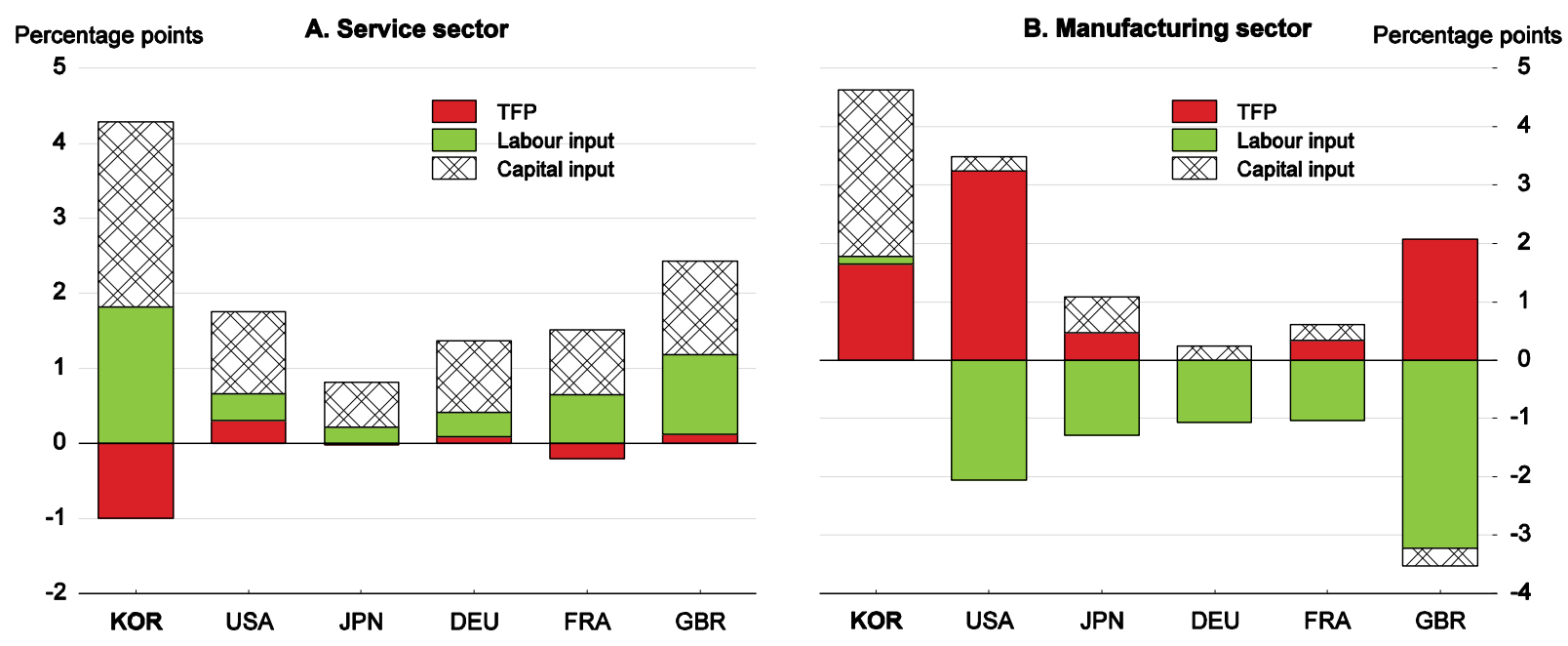

1. 2001-10 for the United States and 2001-09 for the other countries.

Source: Korea Productivity Centre (2014).

Figure 6. The service sector has a low capital stock and its links to manufacturing are weak

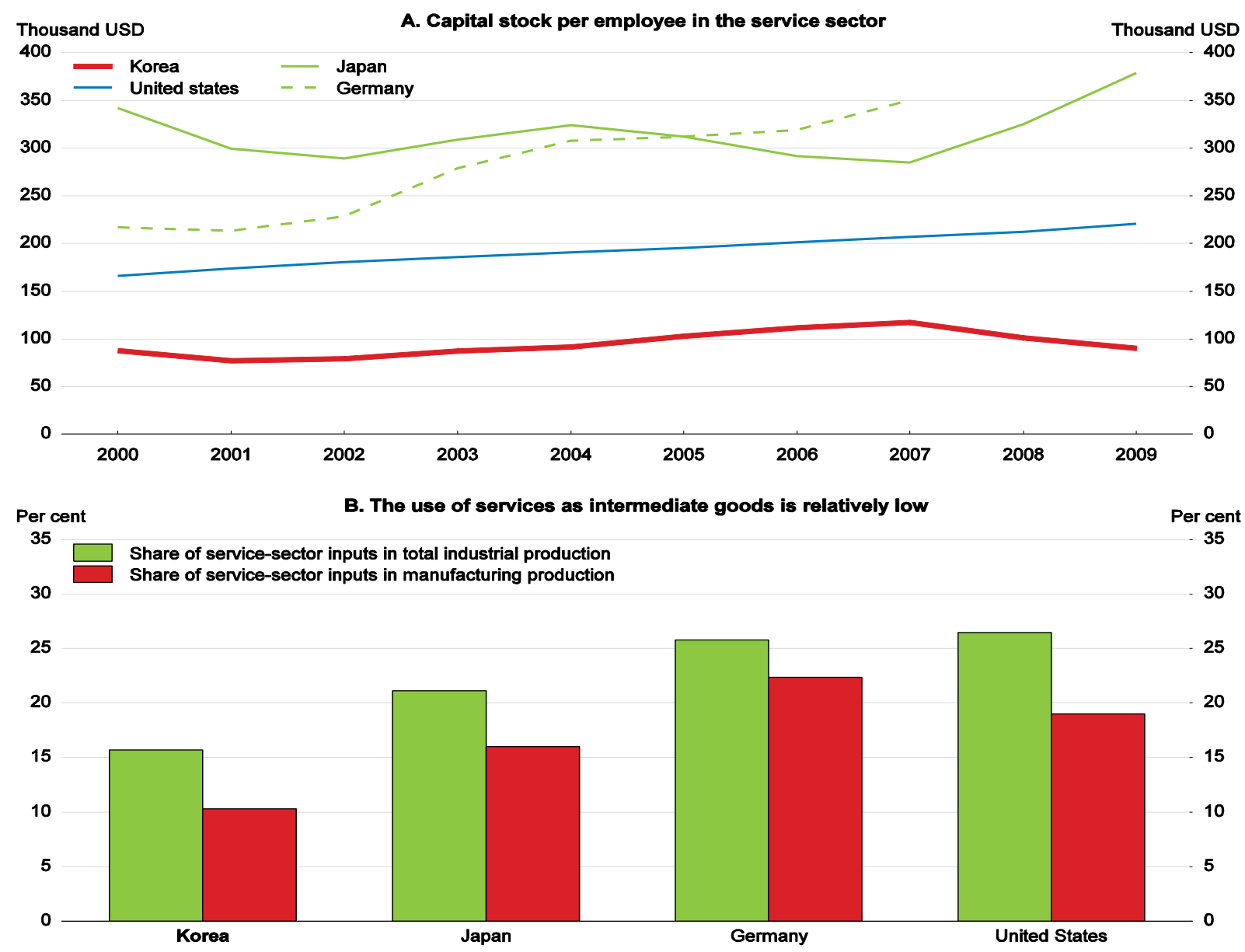

Source: Baek and Joo (2014a). 
To promote the service sector, the government launched the "2013 Service Industry Policy Directions and Measures", which aim to: $i$ ) ensure equal tax treatment between services and manufacturing; $i$ ) improve financial support from the public sector; iii) enhance the social image of services; $i v$ ) foster human capital in services; and v) provide support for service-sector start-ups. Ending discrimination is certainly needed for efficient resource allocation. The development of the service sector also depends on framework conditions to promote competition.

The service sector is dominated by SMEs, which account for around $90 \%$ of service-sector employment and operating profits. For the whole economy, SMEs accounted for $77.5 \%$ of workers, whose average pay was $42 \%$ of those in large firms (Table 1). Workers in "core SMEs", in turn, are paid 3.7 times more on average than those in micro-firms; $36 \%$ of micro-firms are created by "necessity-driven" entrepreneurs who have no other option for work (Global Entrepreneurship Monitor, 2012). This share is high compared to other OECD countries, reflecting the fact that workers leave firms at age 53 on average and have little retirement income (Jones and Fukawa, 2016). Productivity in the SME sector as a whole has fallen from 53.8\% of that in large companies in 1988 to only $30.5 \%$ in 2014, as large enterprises scaled up investment in labour-saving technology following Korea's democratisation in 1987, which resulted in large-scale wage increases. In the wholesale and retail trade sector, the labour productivity of mediumsized firms (50-299 employees) was only 62\% of large firms (Figure 7). In contrast, medium-sized firms in most OECD countries outperform large ones. This large productivity gap between large firms and SMEs limits Korea's economic growth.

Table 1. A comparison of SMEs and large firms in Korea in 2010

\begin{tabular}{c|rr|rr|r}
\hline & Large firms & SMEs & \multicolumn{2}{|c|}{ Of which: } & Total \\
& & & Core SMEs & Micro-firms ${ }^{1}$ & \\
\hline Number of enterprises $^{2}$ & 4.8 & 3152.9 & 244.5 & 2908.3 & 3157.7 \\
Per cent & 0.2 & 99.8 & 7.7 & 92.1 & 100.0 \\
Number of workers $^{2}$ & 3803.2 & 13131.6 & 6349.4 & 6782.2 & 16934.8 \\
Per cent $^{*}$ & 22.5 & 77.5 & 37.5 & 40.0 & 100.0 \\
Operating profit $^{3}$ & 181.2 & 113.5 & 54.4 & 59.1 & 294.7 \\
Per cent & 61.5 & 38.5 & 18.5 & 20.1 & 100.0 \\
Operating profit per firm $^{4}$ & 37609.0 & 36.0 & 222.5 & 20.3 & 93.3 \\
Average wage $^{5}$ & 36.5 & 15.2 & 24.5 & 6.6 & 20.0 \\
\hline
\end{tabular}

1. Firms with less than five workers in services and less than ten in other sectors.

2. Thousands.

3. Trillion KRW

4. Billion KRW.

5. Million KRW.

Source: Statistics Korea, 2010 Economic Census.

\section{Appropriate framework conditions are needed to increase productivity}

The widening gap between Korea's large firms, which include many major exporters and world leaders, and small firms suggests a problem of diffusion and resource reallocation. Indeed, productivity growth depends as much on improved resource allocation as on technological progress and innovation (Andrews et al., 2015). Productivity is increased by the expansion or entry of high-productivity firms and the contraction or exit of low-productivity ones. Young firms play an important role as they often have a comparative advantage in commercialising innovations. Firms less than five years old, regardless of their size, accounted for less than a fifth of total non-financial business employment in the OECD but generated half of all new jobs over 2001-11 (OECD, 2013b). The success of Korea's creative economy strategy thus depends to a large extent on raising the rate of both business creation and the rate of exit, as a long tail of unproductive firms can slow down aggregate productivity growth. However, the entry and exit rates in 
both manufacturing and services - a measure of economic dynamism - have slowed markedly between 2001 and 2013, although they increased somewhat in 2014-15 (Figure 8). Creative destruction and resource reallocation can be impeded by regulations and public support for weak companies. Limiting the entry of new companies to protect existing ones results in huge opportunity costs in terms of foregone productivity gains.

Figure 7. Korea has a wide labour productivity gap between SMEs and large firms Labour productivity in wholesale and retail trade: ${ }^{1}$ labour productivity for large firms $\left(250+\right.$ employees) is set at $100^{2}$
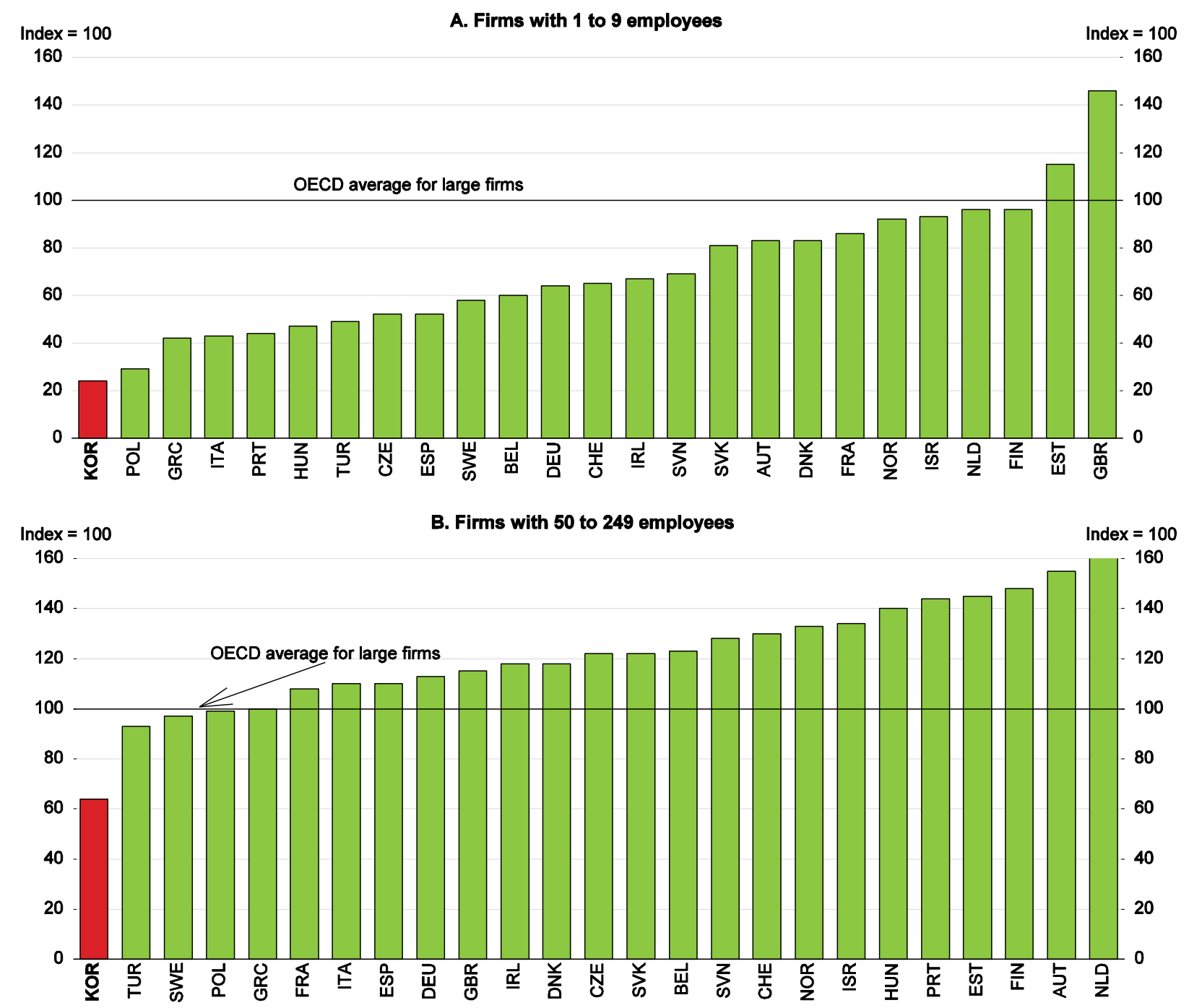

1. In 2012. Includes the repair of motor vehicles and motorcycles.

2. For Korea, the size class "50-249" refers to "50-299" and the size class "250+" refers to "300+".

Source: OECD (2015d).

Regulation is an essential instrument used by governments to achieve policy objectives, such as economic growth, social welfare and environmental protection. It includes: $i$ ) economic regulation intended to improve the efficiency of markets in delivering goods and services; $i$ i) social regulation aimed at protecting the environment and the safety and health of society; and iii) administrative regulation to ensure government oversight of private-sector activities (OECD, 2015c). However, when poorly conceived, regulations can be ineffective in achieving their objectives while imposing unnecessary costs on citizens and businesses. In particular, the regulatory framework has an important impact on innovation. 
Stringent product market regulations tend to discourage entry by new firms and the effective diffusion of knowledge, while reducing private investment in innovation. Moreover, restrictive regulations make it difficult for firms to attract the resources needed to implement and commercialise new ideas (Westmore, 2013).

Figure 8. Entry and exit rates have fallen in both the manufacturing and service sectors

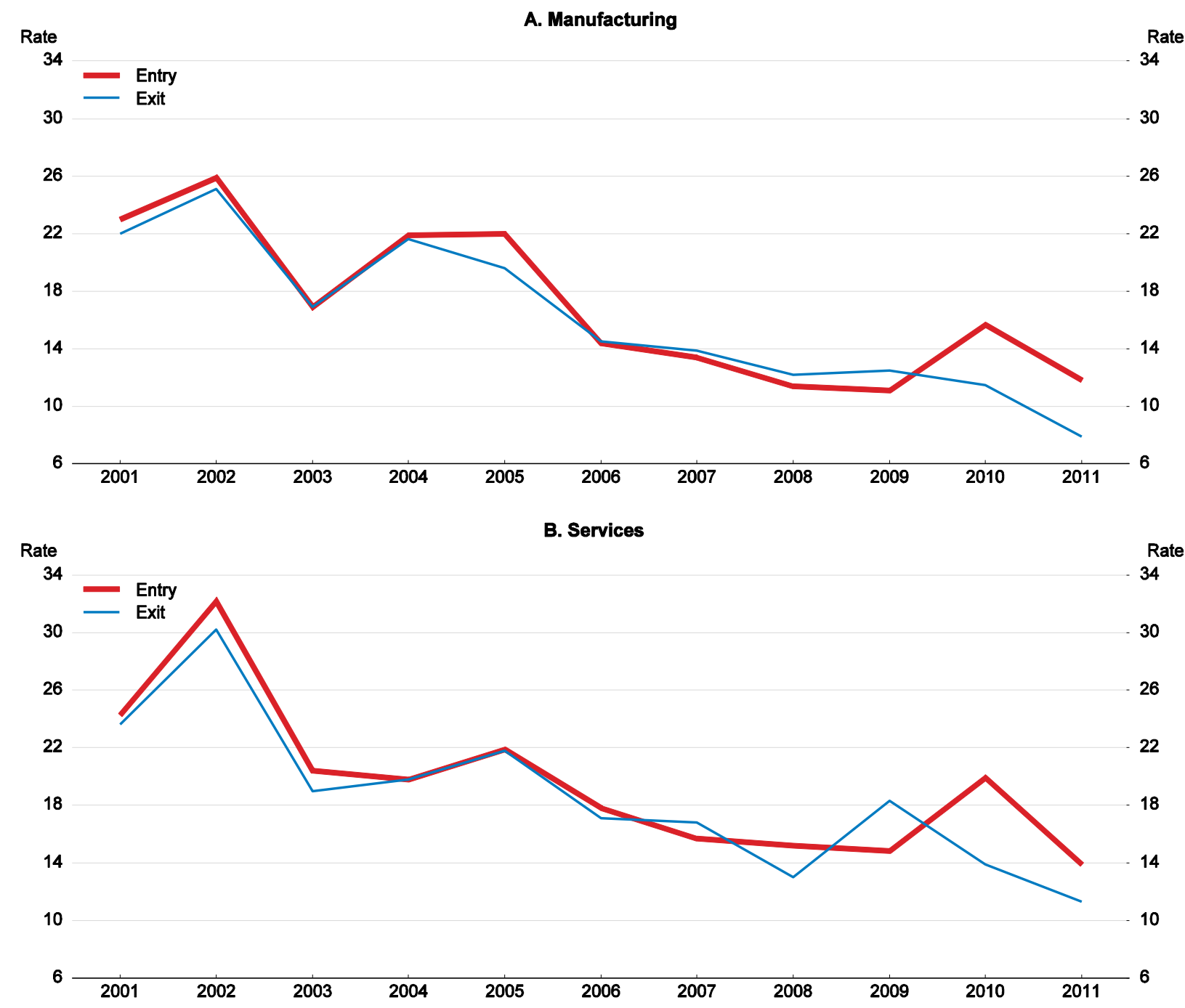

Source: Ahn (2015).

Productivity can vary widely between industries depending on the regulatory framework. A study of five service industries in Korea found that productivity growth ranged from $18 \%$ in retail trade to minus 9\% in personal services (Figure 9). In retail, regulation is relatively low compared to other OECD countries (Panel B), thanks to significant deregulation during the 1990s. Consequently, the impact of entry and exit and reallocation of resources to high-productivity firms and away from low-productivity firms accounted for 14 percentage points of the productivity gain. Competition from new entrants was also a factor in the productivity contribution from existing firms (the "within effect").

In Korea, SMEs which achieved rapid TFP growth over 2007-11 did not have a higher share of output in 2011 (Chang, 2015). The failure of successful enterprises to expand indicates problems in resource allocation. Moreover, only $0.01 \%$ of small companies grew into medium-sized companies over 2011-14. 
This section focuses on product market regulation, a top government priority, in addition to international openness and labour mobility, which also affect resource reallocation.

Figure 9. Productivity growth in service industries varies widely

A. Contributions to productivity growth over the period 2005-10

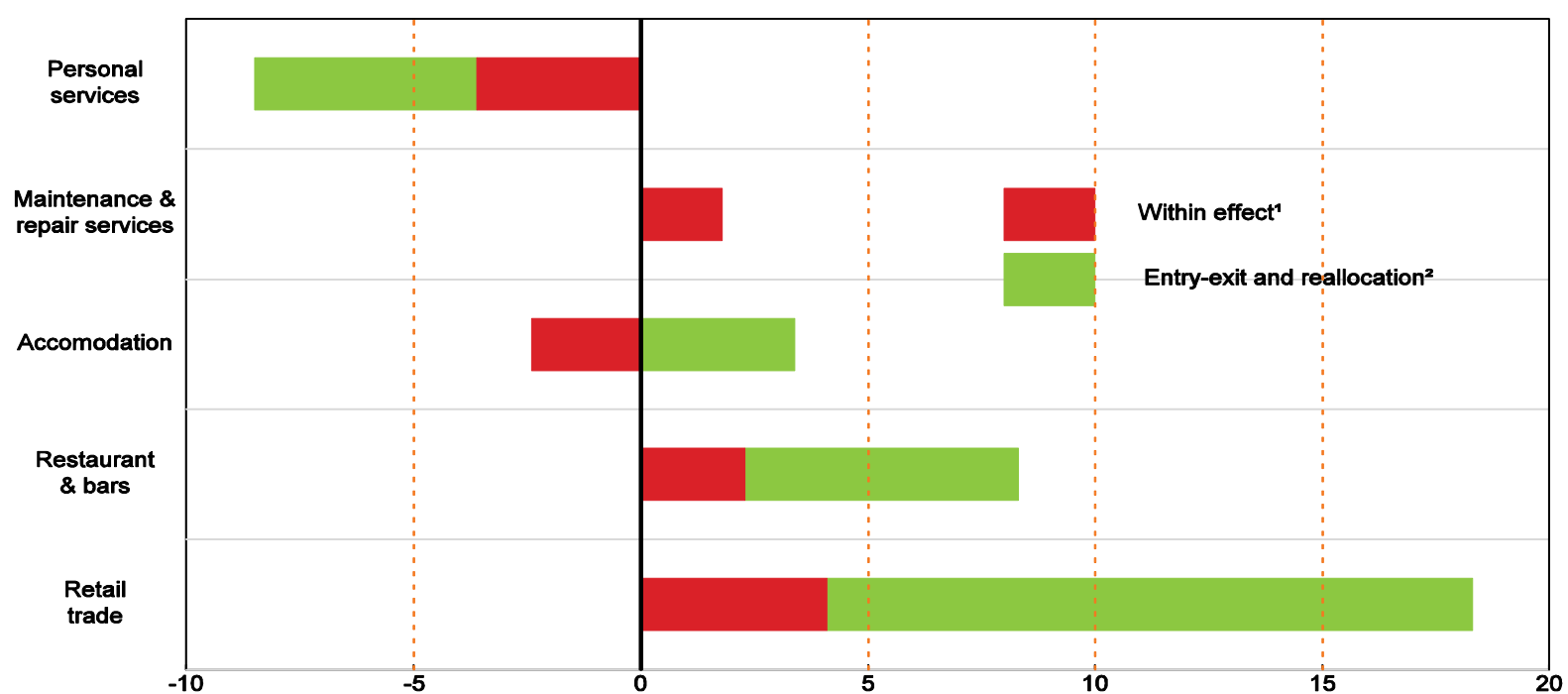

B. Regulation in Korea's retail sector is not very restrictive ${ }^{3}$

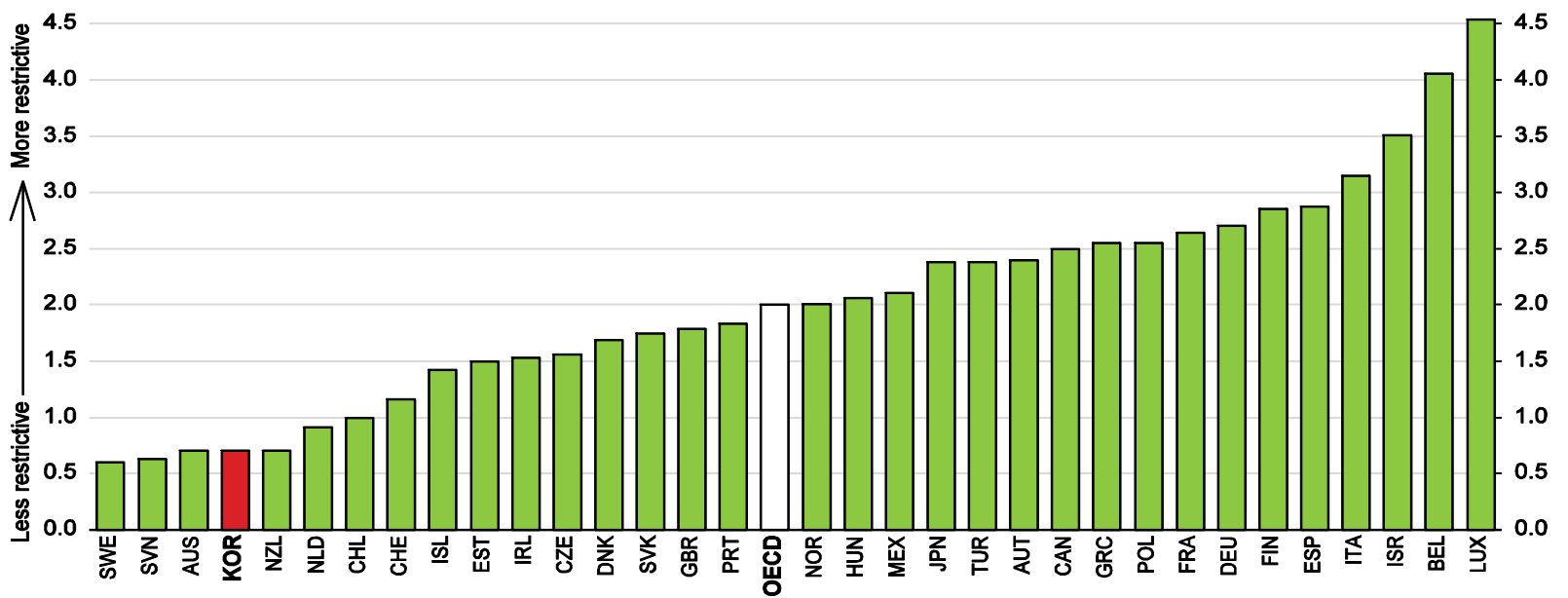

1. The with-in effect shows the productivity change in firms that remain in the industry.

2. The entry-exit effect shows the productivity effect from the entry of new firms and exit of existing firms. The reallocation effect shows the impact of the expansion of productive firms and the contraction of less-productive firms.

3. Based on the OECD Indicators of Product Market Regulation, a comprehensive and internationally-comparable set of indicators that measure the degree to which policies promote or inhibit competition.

Source: Choe et al. (2014); Koske et al. (2015); OECD Product Market Regulation Database (http://oecd.org/eco/growth/indicatorsofproductmarketregulationhomepage.htm).

\section{Regulatory reform to boost competition and productivity}

Regulations are realtively stringent, especially in the service and SME sectors

In the wake of the 1997 crisis, Korea launched a regulatory reform programme that reduced the number of registered regulations at the central government level from more than 10000 in 1998 to less than 7000 within two years (Figure 10). In 2004, the government started the "Total Regulation Control 
System", which aimed to limit the annual increase in the number of regulations by each ministry to $2 \%$. However, this approach allowed ministries to replace minor regulations with significant ones or to combine two regulations into one. Lacking support from ministries, this system only lasted for two years. The number of regulations more than doubled to more than 15000 by 2013. In addition, Korea has nearly 5000 unlisted regulatons based on law. At the local government level, a central government study in 2014 found 6440 regulations in 11 major sectors based on local ordinances and rules.

Figure 10. The number of regulations rose quickly until $2013^{1}$

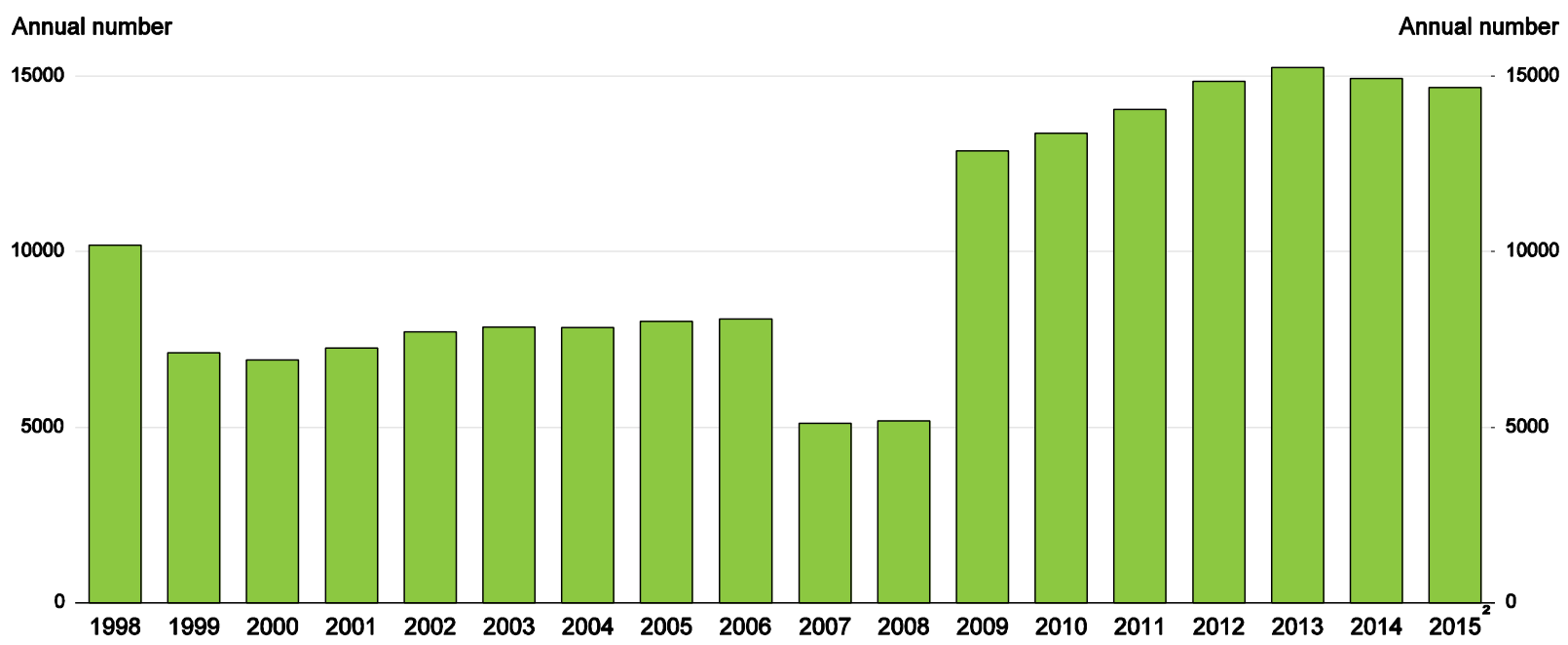

1. The number at year-end. The numbers reported for 2007-08 are affected by a change in the method of counting regulations.

2. In June 2015. The government has stopped releasing data on the number of regulations as it shifts to a goal of capping the regulatory burden.

Source: Park (2015a).

In addition to the high level of regulation, the Sewol Ferry tragedy in 2014 highlighted problems in regulatory governance, including corruption and incompetence (Lim, 2014). Another concern is the widespread use of administrative guidance, which is inconsistent with a transparent and predictable regulatory framework. Administrative guidance is defined as advice, recommendations, discretionary application of licensing criteria or other actions by regulatory bodies that do not have binding legal force, but are intended to affect actions and behaviour. It has long been a concern for both domestic and foreign companies in Korea, where the government has played an active role in economic activities (OECD, 2007).

Administrative guidance has been a major issue in the financial sector, where the supervisory authority has been involved in the activities of private financial institutions in the guise of prudential regulation. For example, the supervisors have advised financial institutions on dividend payments and the setting of fees and interest rates. A 2014 review found almost 2000 shadow regulations - administrative guidance and best practices. Such interference has reduced incentives to develop creative financing and led to a uniform structure across financial institutions (Kim, 2015). Since 2014, the government has pursued extensive regulatory reform, including improving administrative guidance.

Korea's product market regulation (PMR) indicator was the fourth most stringent in the OECD in 2013 (Figure 11). The service sector is particuarly regulated; by 2013, it was subject to 4336 regulations, four times higher than in manufacturing (Park et al., 2014). This included 3660 "core regulations" (which exclude secondary measures related to the implementation of core regulations), ten times more than in manufacturing. The concentration of regulations in services is reflected in the OECD's PMR indicator in seven key network industries, which ranks Korean regulation as the fifth most stringent in the OECD (Panel B). Korea ranks close to the OECD average for professional services (Panel C). 
Figure 11. Korea's product market regulations are relatively stringent

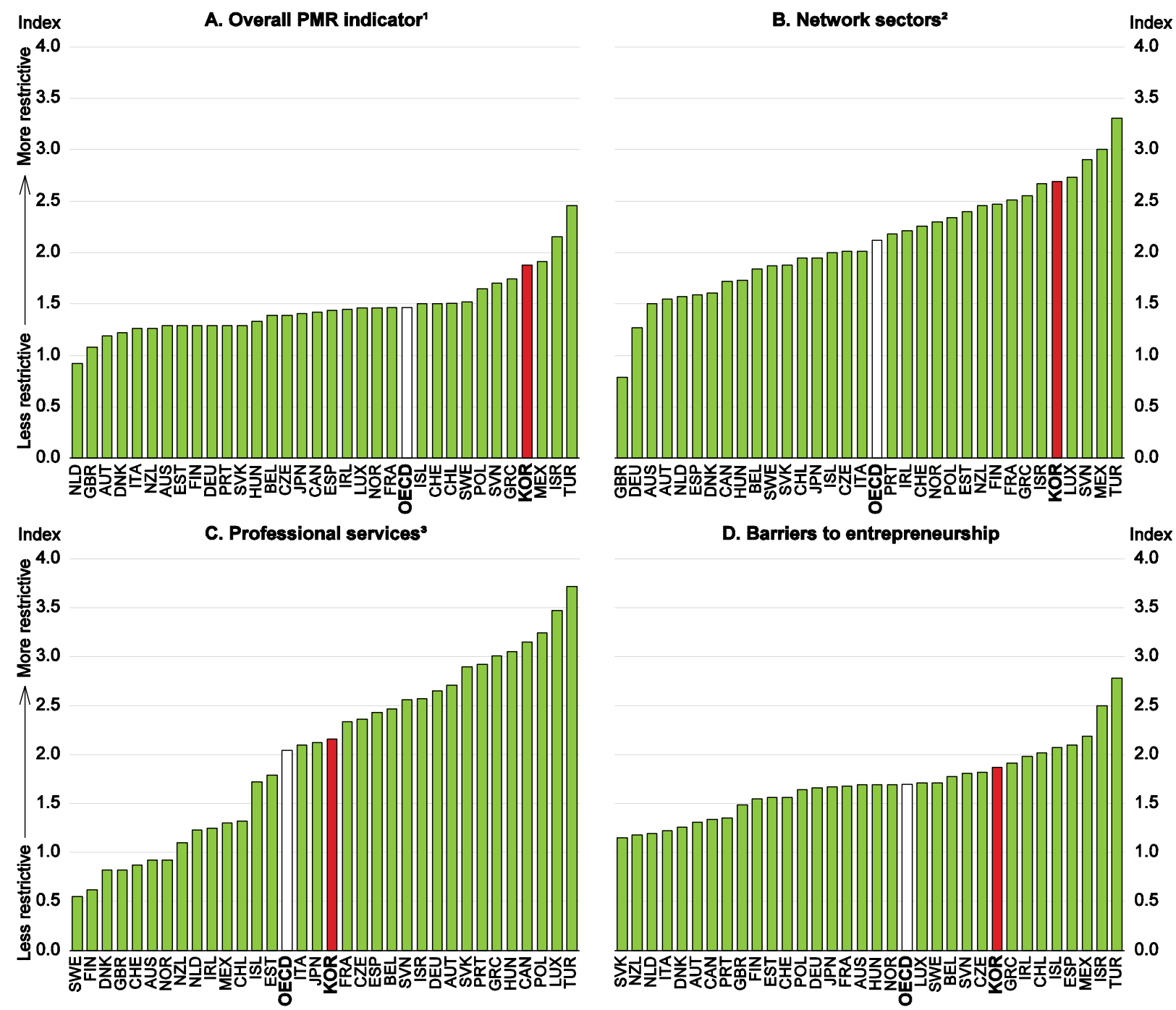

1. The OECD Indicators of Product Market Regulation are a comprehensive and internationally-comparable set of indicators that measure the degree to which policies promote or inhibit competition. Empirical research shows that the indicators have a robust link to performance. The indicator, which ranges from zero (most relaxed) to four (most stringent), is available for 33 OECD countries. The overall indicator is based on more than 700 questions.

2. Includes electricity, gas, telecom, postal services, rail, airlines and road transport.

3. Includes accounting, legal, architecture and engineering.

Source: Koske et al. (2015); OECD Product Market Regulation Database (http://oecd.org/eco/growth/indicatorsofproductmarketregulationhomepage.htm).

Barriers to entrepreneurship in Korea were the seventh highest in the OECD area in 2013 (Figure 11, Panel D). Entry barriers impede the creative destruction needed to boost productivity growth. A study covering 23 sectors in Korea found that entry regulations reduce both entry and exit rates. In addition, relaxing entry barriers raises employment and TFP growth, while exit also boosts TFP growth (Ahn, 2015; OECD, 2015f).

The PMR has a significant relationship with aggregate productivity across OECD countries; more restrictive regulation leads to lower aggregate productivity (Koske et al., 2015). Reducing Korea's PMR would stimulate private investment in innovative activities, the diffusion of knowledge, improved managerial performance and entry by new firms. The impact of regulation is greatest in the service sector. Several studies have found a significant negative relationship in Korea between the level of regulation and 
TFP growth in services (Park et al., 2014; Han and Inn, 2008). Moreover, regulatory reform has had a significantly positive effect on TFP in services such as finance, healthcare and professional services.

Because SMEs dominate services, the number of regulations applied to SMEs is large. In 2013, it was estimated that 8921 regulations - 59\% of the total number -- applied to SMEs (Table 2). Economic regulations covering entry, price, trading and quality, which distort the functioning of markets, accounted for about one-third of SME regulations. Another third were social regulations on environment, industrial accidents, consumer safety and social discrimination. While such regulations are important to achieve noneconomic objectives, they tend to have a heavier impact on smaller firms.

Table 2. There are a large number of economic regulations on SMEs ${ }^{1}$

In June 2013

\begin{tabular}{llcr}
\hline \multicolumn{2}{c}{ Type of regulation } & $\begin{array}{c}\text { Number of } \\
\text { regulations }\end{array}$ & $\begin{array}{c}\text { Percentage of } \\
\text { total }\end{array}$ \\
\hline & Entry & 154 & 1.9 \\
Economic regulations & Price & 1012 & 12.2 \\
& Trading & 1092 & 13.2 \\
& Quality & 606 & 7.3 \\
& Sub-total & $\mathbf{2 8 6 4}$ & $\mathbf{3 4 . 5}$ \\
Social regulations & Environment & & \\
& Industrial accidents & 806 & 9.7 \\
& Consumer safety & 423 & 5.1 \\
& Social discrimination & 1440 & 17.4 \\
Administration regulations & Sub-total & 279 & 3.4 \\
Total & & $\mathbf{2 9 4 8}$ & $\mathbf{3 5 . 6}$ \\
\hline
\end{tabular}

1. Regulations that are either legally limited to SMEs, pertain to sectors where practically all firms are SMEs or cited by SME associations as important to their member firms.

Source: Cho and Kim (2013).

SME regulations can also be classified by firms' stage of development (Table 3). There are nearly 2000 regulations applied to the creation of enterprises. Business activity regulations, focusing on administration and production, account for three-quarters of regulations facing SMEs. In sum, the creation of SMEs and their business activities have long been hindered by a large number of regulations.

Regulation is still an important issue in the manufacturing sector. Entry and exit barriers weaken competition in manufacturing, slowing the process of creative destruction, which is key to productivity growth (B. Lee, 2014). Indeed, the entry rate in manufacturing fell significantly from $22.7 \%$ in 2001 to $15.3 \%$ in 2011 . In industries where the entry rate is below average, such as beverages $(10.1 \%)$ and medical devices $(10.4 \%)$, TFP growth was negative. In contrast, in industries with above-average entry rates, such as apparel (16.7\%) and electronic equipment (16.4\%), TFP growth was positive. Lowering entry barriers, therefore, would boost productivity.

\section{Recent regulatory reform initiatives by the government}

Regulatory reform has long been stymied by conflicts between competing interest groups and excessive reliance on regulation as the best way to resolve problems. For example, some reforms, such as allowing telemedicine for patients in rural areas, have been pending for a decade. Moreover, legislation intended to reform the service sector, such as the "Service Sector Development Framework Act" submitted in 2012, is still pending in the National Assembly. Opposition to reform of social services, such as health, reflect concerns that it will undermine the public provision of such services. In addition, some fear that 
regulatory reform will open the door to further expansion by the chaebols. Two key regulations that large firms find most onerous - restrictions on their activities in certain sectors in order to protect SMEs and limits on construction in the Seoul metropolitan area - have strong political support to achieve noneconomic objectives. Perhaps most importantly, the Sewol Ferry tragedy is casting a long shadow over debates on regulatory reform.

Table 3. Economic regulations on SMEs by type of activity

In June 2013

\begin{tabular}{llrr}
\hline \multicolumn{2}{c}{ Type of regulation } & Number of regulations & Per cent of total \\
\hline \multirow{3}{*}{ Creating an enterprise } & Founding & 1247 & 15.0 \\
& Building & 310 & 3.7 \\
& Location & 264 & 3.2 \\
& Sub-total & $\mathbf{1 2 2 . 0}$ & 25.8 \\
& Administration & 2143 & 13.0 \\
& Production & 1075 & 11.0 \\
& Sales & 912 & 7.7 \\
& Personnel & 635 & 5.3 \\
Business activities & Finance & 442 & 4.9 \\
& Safety & 407 & 4.1 \\
& Environment & 343 & 2.5 \\
& International trade & 208 & 0.7 \\
& Technology & 62 & $\mathbf{7 5 . 1}$ \\
& Sub-total & $\mathbf{6 2 2 7}$ & 1.0 \\
& Merger & 84 & 0.0 \\
M\&As and business transition & Sale of assets & 4 & 0.0 \\
& Sector switching & 1 & $\mathbf{1 . 1}$ \\
Family business succession & Sub-total & $\mathbf{8 9}$ & 0.8 \\
Closure \& company clean-up & & 65 & 1.1 \\
\hline Total & & 89 & $\mathbf{1 0 0 . 0}$ \\
\hline
\end{tabular}

Source: Cho and Kim, (2013).

The government launched a comprehensive regulatory reform effort in 2013 based on two priorities: i) promoting the development of a creative economy and encouraging investment in the service sector; and ii) strengthening regulations related to safety, the environment and consumer protection to assuage public concerns. In 2014, this was supplemented by two additional objectives:

- Concentrating regulatory reform in promising service industries (see below).

- Focusing reform on core regulations that hinder business activities.

To achieve these objectives, the government pledged to reduce the number of economic regulations, which totalled around 10000 in 2014 , by $10 \%$ by January 2015 . To accelerate regulatory reform, it also introduced a range of new initiatives (Box 1).

However, the economic burden of regulation depends more on the quality of regulation than on their number. The government's focus thus shifted in 2014 from quantitative to qualitative targets. It launched the "cost-in, cost-out" (CICO) system. This approach, a type of regulatory budget, is similar to the approach of the United Kingdom; any new regulation that is expected to impose a direct incremental net cost on business must be offset by measures that provide savings that are at least equal to that amount. Estimates of the costs and savings are found in the Regulatory Impact Assessments (RIAs) that have been required by law since 1988. Certain regulations, such as those related to protecting people's lives and safety, are exempted. CICO was introduced on a pilot basis in eight ministries and agencies in July 2014 
and expanded to 15 in April 2015. If the system is judged to be a success, it will be extended to most other ministries in 2016.

\section{Box 1. Regulatory reform initiatives}

The Regulatory Reform Committee (RRC), established in 1998, has set the direction for regulatory reform. The $\mathrm{RRC}$, which consists of 19 private-sector experts and six government ministers, is responsible for responding to public opinion, reviewing new and amended regulations and evaluating each ministry's efforts to improve regulations. Given the renewed priority attached to regulatory reform, the government has launched a range of initiatives to supplement the work of the RRC:

- $\quad$ The Regulatory Reform Ministerial Meeting, which is chaired by the President, includes relevant ministers, directors of major economic organisations, academic experts and the general public. The meetings, which began in March 2014, focus on priorities for job creation and economic revitalisation via regulatory reform. Thus far, four meetings have been held.

- $\quad$ The Regulatory Guillotine solicits reform ideas from major business organisations. Of the 329 proposals made during the first and second rounds, 189 regulations were improved or eliminated by the end of 2015. However, of the 112 regulations improved or eliminated during the first round, the government estimated that only 18 will boost investment and employment.

- $\quad$ The Thorn under the Nails initiative aims at addressing chronic regulatory problems that are burdensome to small firms. Of the 426 proposals received, 386 had been resolved by the end of 2015 .

- $\quad$ The Regulatory Reform Shinmungo, which was introduced in March 2014, allows citizens to directly propose regulatory reforms. Once an idea is submitted, the relevant ministry has two weeks to determine whether to pursue the reform. If so, it must be resolved within three months. Even if the proposed reform is not accepted, the Office for Government Policy Co-ordination (OPC) has to consider the merits of the proposal. Finally, the RRC can recommend that the regulation be improved. In addition to the three-part approach, this system is unique in several aspects. First, ministry officials must respond to citizens' proposals using their own name, leading to increased accountability and transparency. Second, it created a single window for receiving regulatory reform ideas to ensure that proposals are not lost in the wrong ministry. The number of citizen requests for specific regulatory reform increased from 300 in 2013 to 7963 (excluding overlapping proposals) since the launch of Shinmungo in 2014. Moreover, the acceptance rate for such proposals rose from $8 \%$ in 2013 to $38 \%$.

- A change in regulatory reform principles: the government is expanding the sunset rule, moving from ex ante to ex post regulation and reviewing all economic regulations from a zero base. In addition, Korea is shifting from a positive-list regulatory system, which specifies which activities are allowed, to a negative-list approach, which specifies the activities that are prohibited.

- Regulatory information disclosure: the establishment of a regulatory information portal allows the public to follow regulatory developments in real time.

The government announced a package of "Measures to Stimulate Investment: Fostering Promising Service Industries" in August 2014 (MOSF, 2014). Seven service industries were selected based on their expected ability to create jobs and enhance Korea's growth potential (Box 2). Regulatory reforms in these industries are aimed at promoting market competition and pioneering new export markets. The emphasis on overseas markets is aimed at expanding the size of the service sector while limiting the need for domestic reforms that would produce winners and losers. Regulatory reform should play an important role as nearly half of the regulations covering the service sector are applied to the seven promising industries. Given that past initiatives to target specific services for growth have not had a significant impact on the service sector, it is important to focus on framework conditions, the innovation system, human capital and SME policies to increase productivity in the entire service sector. 


\section{Box 2. Current government's policy direction for regulatory reform in the service industry}

Reform measures for services are decided by the "service-sector advancement committee" that is controlled by the Ministry of Strategy and Finance (MOSF). Its 2014 initiative established quantitative targets for 2017 in each of the seven promising sectors (Table 4). To achieve these targets, 135 tasks were outlined, which aim to create new markets, provide customised government support and promote the growth of successful sectors. Progress toward the 2017 targets was achieved in four of the promising sectors in 2014 . The main policies include:

- Medical care: i) enable hospitals and other healthcare providers to establish for-profit hospital subsidiaries; ii) ease regulations to allow the establishment of foreign-owned hospitals in Jeju island and in the Free Economic Zones; iii) attract foreign patients and make Korea the premier medical tourist destination in Asia by enacting the "Special Act for International Medical Care"; and iv) promote the establishment of Korean medical institutions overseas to promote exports of medical technology.

- Tourism and culture: i) expand tourism infrastructure in order to capitalise on the increasing popularity of Korean culture (the Korean wave); ii) reform regulations related to the construction of resort complexes; iii) attract global theme parks by establishing incentives and relaxing regulations; and iv) promote tourism in mountainous areas.

- Education: i) eliminate regulations and discrimination in order to encourage foreign universities to open campuses in Korea; and ii) increase the number of foreign students studying in Korea.

- Finance: i) create a service industry support fund with 3 trillion KRW (USD 2.6 billion) of public money over the next three years; and ii) promote the listing on stock markets of enterprises with strong growth potential by increasing incentives and revising regulations.

- Logistics: i) increase the number of logistics parks; ii) develop the Incheon International Airport Free Trade Zone as a global logistics hub by introducing high-speed freight trains and attracting global distribution centres; and iii) allow freight vehicles to use an electronic toll payment system.

- Software: i) encourage private-sector investment in software industries and ICT by establishing hightechnology communities in Busan, Pangyo and Songdo in 2014; ii) approve the launch of new TV home shopping channels; and iii) expand overseas market opportunities for software companies.

Table 4. Policy goals for the expansion of promising service industries

\begin{tabular}{|c|c|c|c|c|}
\hline Industry & Goal & $\begin{array}{c}2013 \\
\text { outcome }\end{array}$ & $\begin{array}{c}2014 \\
\text { outcome }\end{array}$ & 2017 goal \\
\hline Medical care & Boost number of foreign patients (thousand persons) & 210.0 & 266.5 & 500.0 \\
\hline Tourism and culture & Increase number of foreign tourists (million persons) & 12.0 & 14.2 & 20.0 \\
\hline Education & Attract world-class foreign universities & 0.0 & 0.0 & 3.0 \\
\hline Finance & Raise the financial sector's share of value-added $(\%)^{1}$ & 6.7 & $\mathrm{n} / \mathrm{a}$ & 8.0 \\
\hline Logistics & Increase sales of the logistics sector (trillion KRW) & 92.0 & 91.7 & 135.0 \\
\hline Software & Exports of software (billion USD) & 4.0 & 5.3 & 7.0 \\
\hline
\end{tabular}

1. The data in the 2013 column are for 2012. Data for 2013-14 are not yet available.

Source: Ministry of Strategy and Finance (2014).

Initial results from the recent regulatory reform initiatives

The government achieved its goal of cutting the number of economic regulations (9 876) by $10 \%$ in the year to January 2015. Moreover, nearly a third of the more than 10000 regulatory reform suggestions made through the Regulatory Reform Shinmungo since March 2014 have been accepted for consideration, leading to the amendment of laws underpinning 2377 regulations. In addition, the Thorn under the Nails, Regulatory Guillotine, and Regulatory Reform Ministerial Meeting (along with other meetings chaired by the president), have examined 796 regulations (Table 5). However, less than a third were in the service sector. Of the 245 service-sector reforms addressed, reviews of 189 have been "completed", which means that they were left unchanged, improved or abolished. The number of service-sector regulations examined 
amounted to only $5.7 \%$ of the total number of regulations in services. Of those reviews, around threequarters have been completed. Regulatory reform in services, where the productivity gains are estimated to be the greatest, has thus lagged behind. Meanwhile, 247 new regulations covering services have been registered since 2013, with the largest share (91) in the finance and insurance sector. In sum, the net number of regulations covering the service sector has increased.

Progress in regulatory reform has also been achieved at the local level. Of the 6440 regulations based on local ordinances and rules that were identified in 2014, around half have been improved. Information on the progress of reform is available on the regulation information portal. The site also has maps showing the progress of local governments in improving regulation. The ranking of 243 local governments by their progress has sparked competition among them.

Table 5. The service sector accounts for less than one-third of regulations that have been examined

Between February 2013 and December 2015

\begin{tabular}{|c|c|c|c|c|c|c|}
\hline & \multirow[b]{2}{*}{$\begin{array}{c}\text { Total } \\
\text { (A) }\end{array}$} & \multirow[b]{2}{*}{$\begin{array}{l}\text { Services } \\
\text { (B) }\end{array}$} & \multirow[b]{2}{*}{$\begin{array}{c}\text { Services' } \\
\text { share (B/A) } \\
\% \\
\end{array}$} & \multicolumn{2}{|c|}{$\begin{array}{l}\text { Status of service-sector } \\
\text { reforms }\end{array}$} \\
\hline & & & & & $\begin{array}{l}\text { Review } \\
\text { completed } \\
\text { (C) }\end{array}$ & $\begin{array}{c}\text { Per cent } \\
\text { (C/B) } \\
\%\end{array}$ \\
\hline \multirow{5}{*}{$\begin{array}{l}\text { Meetings } \\
\text { chaired by } \\
\text { the } \\
\text { president }\end{array}$} & Regulatory Reform Ministerial Meeting $\left(1^{\text {st }}-4^{\text {th }}\right)$ & 90 & 41 & 45.6 & 32 & 78.0 \\
\hline & Trade and Investment Promotion Organisation & 22 & 17 & 77.3 & 13 & 76.5 \\
\hline & National Science and Technology Advisory Council & 6 & 0 & 0.0 & 0 & n.a. \\
\hline & National Economic Advisory Council & 4 & 0 & 0.0 & 0 & n.a. \\
\hline & Sub-total & 122 & 58 & 47.5 & 45 & 77.6 \\
\hline \multicolumn{2}{|c|}{ On-site meetings } & 9 & 3 & 33.3 & 2 & 66.7 \\
\hline \multicolumn{2}{|c|}{ Thorn under the Nails $\left(1^{\text {st }}-4^{\text {th }}\right)$} & 428 & 94 & 22.0 & 79 & 84.0 \\
\hline \multicolumn{2}{|c|}{ Regulatory Guillotine $\left(1^{\text {st }}-2^{\text {nd }}\right)$} & 237 & 90 & 38.0 & 63 & 70.0 \\
\hline \multicolumn{2}{|c|}{ Total $^{1}$} & 796 & 245 & 30.8 & 189 & 77.1 \\
\hline
\end{tabular}

1. Excludes regulatory reforms taken through the Regulatory Reform Shinmungo.

Source: Data in the government's Regulatory Information Portal, re-classified and calculated by Park (2015b) and the OECD.

In June 2013, the government identified 1845 regulations on business activity and found that only $21.3 \%$ were negative-list regulations, which prohibit certain activities (Table 6). After reviewing the positive-list regulations, which allow certain activities, 204 were transformed into negative-list regulations, bringing their share to $32.4 \%$, thereby reducing the burden of regulations on firms. Another 228 positivelist regulations were improved by expanding the scope of activities that they allow. Nevertheless, about two-thirds of regulations on business activity remain positive-list regulations.

The government has made significant progress in expanding the use of a sunset rule. The initial rule introduced in 1997 stated that when a new regulation is created or an existing one reinforced, the government can: i) specify the date when the regulation will automatically expire; or ii) specify a date for its review within five years. Most regulations, though, are excluded from the sunset rule. At the end of 2013, the sunset rule covered $15.2 \%$ of the 15265 registered regulations, with only 57 in the category of automatic expiration. At the beginning of 2014, the sunset rule was extended to existing regulations and the government set a goal of increasing its coverage to at least $30 \%$ by end-2014 and to $50 \%$ by end- 2017 . The first goal was met as the number of regulations covered by the sunset rule more than doubled to $32 \%$ by end-2014. However, only 70 of the 4767 regulations now covered are subject to automatic expiration. 
Table 6. The number of negative-list regulations on business activity has increased

\begin{tabular}{|c|c|c|c|c|}
\hline & $\begin{array}{c}\text { Total } \\
\text { regulations on } \\
\text { business } \\
\text { activity }\end{array}$ & $\begin{array}{l}\text { Number of } \\
\text { negative-list } \\
\text { regulations in } \\
\text { June } 2013\end{array}$ & $\begin{array}{c}\text { Number of } \\
\text { negative-list } \\
\text { regulations after } \\
\text { reform }\end{array}$ & $\begin{array}{c}\text { Positive-list regulations } \\
\text { that were improved }\end{array}$ \\
\hline Total & $\begin{array}{c}1845 \\
(100.0 \%)\end{array}$ & $\begin{array}{c}393 \\
(21.3 \%)\end{array}$ & $\begin{array}{c}597 \\
(32.4 \%)\end{array}$ & $\begin{array}{c}228 \\
(12.4 \%)\end{array}$ \\
\hline $\begin{array}{l}\text { Entry } \\
\text { requirement }\end{array}$ & $\begin{array}{c}746 \\
(100.0 \%)\end{array}$ & $\begin{array}{c}118 \\
(15.8 \%)\end{array}$ & $\begin{array}{c}298 \\
(39.9 \%)\end{array}$ & $\begin{array}{c}103 \\
(13.8 \%)\end{array}$ \\
\hline $\begin{array}{l}\text { Business } \\
\text { management }^{2}\end{array}$ & $\begin{array}{c}1099 \\
(100.0 \%)\end{array}$ & $\begin{array}{c}275 \\
(25.0 \%)\end{array}$ & $\begin{array}{c}299 \\
(27.2 \%)\end{array}$ & $\begin{array}{c}125 \\
(11.4 \%)\end{array}$ \\
\hline
\end{tabular}

1. Includes regulations on location of businesses, their funding and procedures for creating new firms and hiring workers.

2. Includes regulations on firms' technology, business administration and logistics, the health of their workers, the environment and other aspects of business activity.

Source: Office for Government Policy Coordination (2013).

\section{Directions for regulatory reform}

Any reform undertaken in Korea must begin with the government. As the government stated in launching the "Key Policy Directions for Financial Regulatory Reform" in 2015, the financial supervisor must change its role from coach to referee, who ensures an appropriate framework to promote competition (FSC, 2015b). This should apply to all regulations. Presidential administrations typically begin with ambitious goals for reform, but subsequently find their plans blocked by the bureaucracy, which defends its control over the economy. Consequently, the fundamental priority is to change the role of the ministries in the economy (Park, Lee and Kim, 2015). Korea's traditional industrial policy and government-led growth is increasingly less effective in a mature economy competing in a globalised world driven by technological change (OECD, 2007).

OECD experience shows that achieving progress in regulatory reform in the face of strong opposition from diverse interest groups requires continuous effort by the government to ensure that the regulatory framework adjusts rapidly to changing conditions. Experience in OECD countries also shows that regulatory reform is most successful when $(\mathrm{OECD}, 2010)$ :

- The authorities have a clear mandate for change and the capability to implement that change.

- The government demonstrates the need for change and the desirability of their proposed solutions to the public and key stakeholders.

- The government provides strong evidence and analysis underlying the arguments for reform.

- There are institutions in place that can manage the reform effectively, from design to implementation.

- The reform has clearly identifiable "owners" and "champions", in terms of both politicians and institutions responsible for taking it forward.

- There is a clear timeframe for design, adoption and implementation.

- There is a strategy for engaging those opposing reform or threatened by it, either to persuade them to support the measures or to overcome their objections, including through compensation.

In the case of Korea, there is scope for progress in each of these areas. As in many other countries, the government does not systematically carry out estimates of the economic gains from planned reforms. Providing strong evidence of the benefits from reform would lead to faster progress in regulatory reform. 
As discussed above, the government's main objective is to prevent any further increase in the regulatory burden through the CICO system that is being gradually introduced since 2014. However, to promote productivity growth, it is important to reduce the regulatory burden from its currently high level, according to the OECD's PMR index. Regulatory reform should focus on the core measures that hinder the reallocation of resources, including through the entry and exit of companies and other regulations that are not market-friendly. An assessment of the impact of reform on competition is a useful tool is this regard.

Achieving the government's objective of capping or even reducing the regulatory burden requires making the CICO as comprehensive as possible. First, it should be extended to all 41 ministries and agencies. Second, all regulations should be listed and covered by the CICO. Third, it should cover local government regulations to the extent possible. More generally, giving local governments a larger role in setting regulation may reduce its burden, as local authorities are closer to the people affected by the burden and have an incentive to increase the competitiveness of their jurisdiction.

The effectiveness of CICO depends crucially on accurate estimates of the cost of new regulations and the gains from those that are eliminated. Since 1998, ministries have been required to submit RIAs to the RRC for any new or strengthened regulation. The RIA must include the rationale for the regulation, a review of options, a cost-benefit analysis and an assessment of its expected effectiveness. However, around $80 \%$ of RIAs have poor cost-benefit analysis according to a 2011 study by the National Assembly Budget Office. The success of CICO depends on making RIAs an effective tool for policymaking, in part by increasing the economic staff at each ministry to raise their quality (Lim, 2015).

Regulatory quality in Korea lags behind the highest-scoring countries in the implementation of key regulatory quality tools. In particular, Korea needs an explicit and mandatory methodology for developing new laws and regulations. Over 2011-13, only $16 \%$ of new laws and regulations were initiated by the executive branch and thus subject to quality control measures, such as RIAs and public consultation (OECD, 2015c). Similar standards should be applied to laws and regulations initiated by the National Assembly. Moreover, competition assessments by the Korea Fair Trade Commission (KFTC) are mandatory for new or amended proposals by the executive branch, but legislation initiated by the National Assembly is exempted. This loophole should be eliminated.

Careful review of regulations to ensure that they are clear and transparent could help reduce the role of administrative guidance. In 2005, the government published a guideline aimed at improving legislation that is vague and thus creates opportunities for guidance. In addition, the decision to ban informal administrative guidance in the financial sector could be extended to other sectors. The first step would be to make clear that firms that do not follow administrative guidance will not be punished.

Shifting from positive-list regulations to a negative-list approach would also reduce the scope for administrative guidance by making clear what actions are not allowed. With two-thirds of regulations on business activity still using a positive-list approach, the scope for improvement is large in this regard. In addition, the coverage of the sunset rule should continue to be expanded, in line with the government's target, while including the number subject to automatic expiration from its current level. The clause requiring that regulations be periodically reviewed should be applied to nearly all regulations.

\section{Other aspects of framework conditions to promote productivity growth}

\section{Openness to international competition}

The liberalisation of barriers to international trade and investment broadens the scope for knowledge diffusion and technological transfer across borders, thus allowing firms to tap into innovation by firms at the global frontier. In addition, it facilitates participation in global value chains (GVCs), which promote the 
diffusion of technology (OECD, 2015f). International openness also encourages more efficient resource allocation; firms that cannot compete in the global market downsize, while those that can, expand production. The increase in the capital stock in a firm that experienced a $10 \%$ increase in patents ranged from $1.7 \%$ to $3.6 \%$ depending on the strictness of trade and investment barriers (Andrews et al., 2014). Countries that are open to trade and investment can benefit more from foreign R\&D and new technologies, spurring domestic innovation (Jaumotte and Pain, 2005). These benefits are maximised by pro-competition PMRs, which intensify incentives for firms to incorporate foreign technologies.

Korea has pursued trade liberalisation through free trade agreements, notably with the European Union (2011), the United States (2012), Australia (2014), Canada (2014), New Zealand (2014), Turkey (2015), China (2015) and Vietnam (2015). The agreement with China should increase Korea's integration within "Factory Asia" and in GVCs. Indeed, the foreign content of Korean exports was $42 \%$ in 2011, the second highest among G20 countries. At the same time, Korea's index of barriers to trade and investment was the second highest in the OECD area in 2013 (Figure 12). Relaxing trade barriers on key service and network industries would yield significant productivity benefits. Korea's service trade restrictiveness index is below the OECD average in 11 of the 18 sectors, but still above the OECD average in some sectors that play a key role in global value chains, such as maritime and air transport, courier services and legal services (Figure 13). Barriers to foreign entry include equity restrictions in sectors such as telecoms and air transport. Some sectors are also less competitive because of state control of major firms, such as the Korea Railway Corporation. Barriers to trade and investment help to explain why the stock of FDI as a share of GDP in Korea was the third lowest in the OECD area, at 13\% in 2014. In addition to explicit barriers, the low stock of FDI reflects the business environment and other domestic restrictions, making regulatory reform key to attracting more FDI.

Figure 12. Korea's barriers to trade and investment are the second highest in the OECD In $2013^{1}$

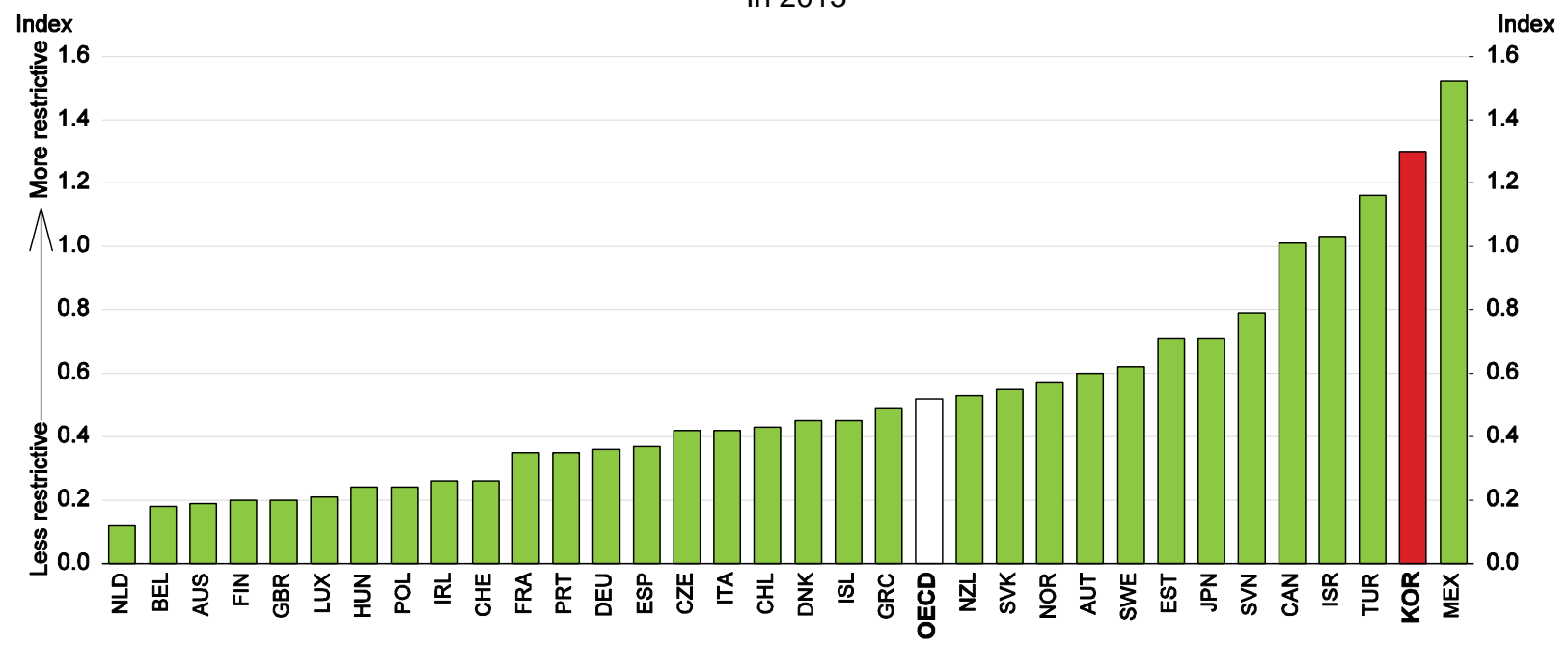

1. From the OECD Indicators of Product Market Regulation, a comprehensive and internationally-comparable set of indicators. Source: Koske et al. (2015); OECD Product Market Regulation Database (http://www.oecd.org/eco/growth/indicatorsofproductmarketregulationhomepage.htm).

\section{Labour market flexibility}

Innovation requires continuous reallocation of labour and other resources within and across firms and sectors. There is considerable evidence that employment protection has a major impact on labour flows (Martin and Scarpetta, 2012). Low levels of protection allow resources to flow to their most productive uses, benefiting firms that undertake innovations that require large employment adjustments. In contrast, employment protection has negative impacts on innovation: 
- It lowers R\&D expenditure, particularly in innovative sectors (Andrews and Criscuolo, 2013). Firms in industries characterised by rapid technological change place a high value on flexibility, given their tendency to experiment with uncertain technologies. By raising exit costs, stringent employment protection makes experimentation less attractive.

- It reduces the ability of innovative firms to attract the resources needed to implement and commercialise new ideas. The increase in the work force in a firm that experienced a $10 \%$ increase in patents ranged from $0.3 \%$ and $2.2 \%$ depending on the strictness of employment protection, while the increase in capital ranged from $0.9 \%$ to $3.3 \%$ (Andrews et al., 2014). Moreover, the negative effect of employment protection falls disproportionately on young firms.

- It discourages investment in technologically-advanced innovation by multinational enterprises.

Figure 13. Korea's service trade restrictiveness is relatively high in some sectors OECD

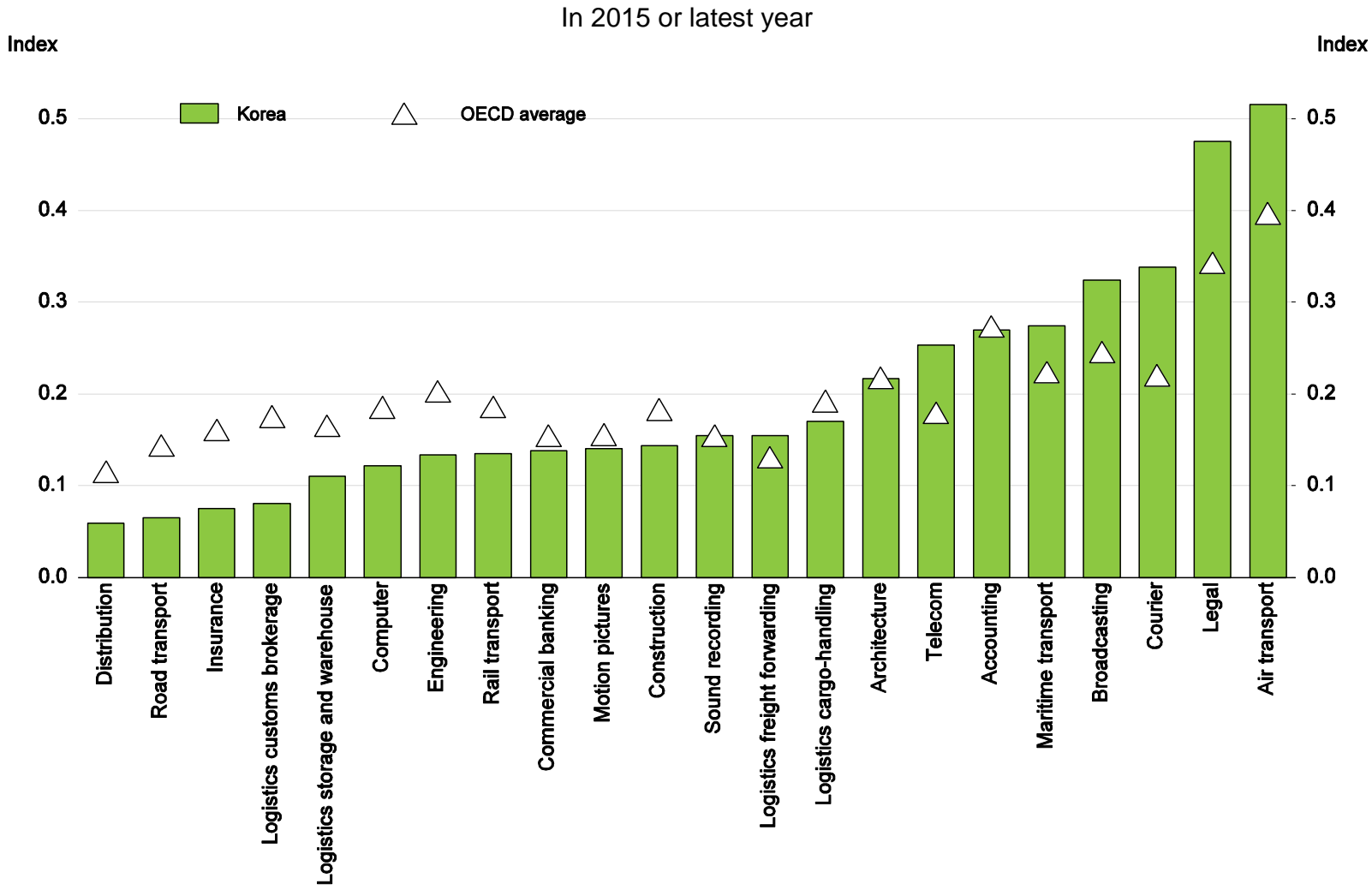

Note: The STRI indices take values between zero and one, one being the most restrictive. They are calculated from the STRI regulatory database which contains information on the 34 OECD countries and some emerging economies. The STRI database records measures taken on a "Most Favoured Nation" basis while excluding preferential trade agreements. Air transport and road freight cover only commercial establishments. The data have been peer reviewed by OECD member countries.

Source: OECD (2016c).

In Korea, employment protection has been a key reason for the rise in the share of non-regular workers, such as fixed-term, dispatched and part-time workers, to around a third of employment (2016 OECD Economic Survey of Korea). Firms hire non-regular workers in large part to enhance employment flexibility and avoid the cost of laying off regular workers, who receive high employment protection as a result of government policies, business practices, social customs and labour unions (Koh et al., 2010). Consequently, the share of temporary workers in Korea in 2014 was $22 \%$, double the OECD average. The 2014 World Economic Forum Global Competitiveness Report ranked Korea $106^{\text {th }}$ in its flexibility in hiring and firing (World Economic Forum, 2015). Relaxing employment protection would increase R\&D 
investment in innovative sectors and enable innovative firms to attract the resources necessary to commercialise new ideas, thereby promoting higher productivity and output growth. In addition, reducing temporary employment would encourage firm-based training and human capital accumulation, thereby enhancing innovation.

\section{Upgrading the innovation system}

Korea is the world's most R\&D-intensive country, investing 4.3\% of GDP in R\&D in 2014. Moreover, the business sector accounts for three-quarters of the outlays, one of the highest shares in the OECD area. Government support for business R\&D as a share of GDP is the highest in the OECD. The emphasis on education and R\&D has made Korea a top player in 11 of the top 20 fastest accelerating technologies (OECD, 2015d). Korea's Third Science and Technology (S\&T) Basic Plan (2013-17) seeks to diversify the Korean economy by orienting policies towards a wider range of sectors and technologies. To increase productivity, it is necessary to fully leverage Korea's large investment in innovation by increasing the role of SMEs and services in innovation.

\section{Expanding the role of the service sector and SMEs in innovation}

Large manufacturing conglomerates in Korea are the main source of business $R \& D$, while the service sector, SMEs and young firms play much smaller roles. Over 2011-13, only $28 \%$ of service firms in Korea introduced some type of innovation, the lowest in the OECD (OECD, 2015d). The manufacturing sector accounted for $90 \%$ of R\&D, compared to only $7 \%$ in services, far below the OECD average of $38 \%$. Only $6.4 \%$ of Korea's service-sector firms were engaged in R\&D activity in 2014, compared to about onequarter in manufacturing, according to a government survey (Table 7). Moreover, the share of service firms engaged in product and process innovation is relatively low, although services do match manufacturing in organisation and marketing innovation. Some studies show that low R\&D is a key explanation of low productivity in services (Baek and Joo, 2014b).

Large firms account for more than two-thirds of R\&D in Korea, with core SMEs (excluding microfirms, those with less than five workers) accounting for another $30 \%$. R\&D per large firm in 2010 was more than 100 times greater than in core SMEs. The small role of SMEs reflects their weaker financial position and limited technological capacity. Moreover, their incentive to invest in $R \& D$ and take risks is weakened by the fears that any efficiency gains will only improve the profit margins of larger companies, who force subcontractors to lower prices in order to sustain the profit margins of large companies.

Table 7. Service firms are less active in R\&D and innovation than those in the manufacturing sector

Percentage of all firms over $2011-13^{1}$

\begin{tabular}{l|c|c|}
\hline & Service sector & Manufacturing sector \\
\hline R\&D activity rate & 6.4 & 22.3 \\
Innovation activity rate in four areas & 27.0 & 30.9 \\
Product innovation & 5.2 & 17.1 \\
Process innovation & 3.7 & 7.4 \\
Organisational innovation & 16.9 & 16.4 \\
Marketing innovation & 13.9 & 12.1 \\
\hline
\end{tabular}

1. The R\&D and innovation activity rates are the number of firms taking part in each activity divided by the total number of firms. The lower rate for services reflects to some extent the fact that their nature is different from manufacturing.

Source: Cho et al. (2014).

Given the obstacles to R\&D by SMEs, the government has launched a number of initiatives, including: i) increasing the share of SMEs in publicly-financed R\&D from $12.4 \%$ in 2011 to $18.0 \%$ in 2017; ii) requiring government research institutes to raise the share of their budgets devoted to SMEs from $7 \%$ in 2012 to $15 \%$ by 2017; and iii) strengthening technological assistance for SMEs through extension 
programmes and innovation vouchers. Increased public spending on R\&D related to SMEs and services could act as a catalyst to induce more private-sector R\&D. Moreover, R\&D incentives should not discriminate against certain service industries. For example, $R \& D$ tax credits, which are limited to "knowledge-based services", should be extended to the entire sector, as is the case in manufacturing. Furthermore, Korea's sizeable R\&D tax credit, at $9.6 \%$ of total national tax credits in 2014 , is not well tailored to the needs of young firms. In particular, the lack of carry-over provisions or cash refunds inhibits the use of this credit by young and small firms, as such businesses typically lose money in the early years of an R\&D project. The design of these incentives should be reviewed to increase their effectiveness in stimulating innovative entrepreneurship (OECD, 2014a).

\section{Improving the quality of universities and government research institutes (GRIs)}

Korea is well-known for its high university graduation rates and total spending at the tertiary level in 2012 was $2.3 \%$ of GDP, one of the highest in the OECD. The share of high school graduates advancing to tertiary education peaked at $83 \%$ in 2008, suggesting an over-emphasis on higher education. Korea still has few world-class universities and produces few high-impact publications by OECD standards (Figure 14, Panel C). While universities employ around three-quarters of PhDs in Korea, they performed only 9.2\% of R\&D in 2014 (Table 8), about half of the OECD average. A greater university role in R\&D would also enhance basic research, which is the key to breakthrough innovations, such as the Internet and aerospace. In Korea, only about $20 \%$ of basic research takes place in universities compared to $50 \%$ to $75 \%$ in other countries (OECD, 2015d).

Table 8. Flows of R\&D funds in 2014

A. R\&D funding

\begin{tabular}{|c|c|c|c|c|c|c|c|}
\hline \multirow[b]{2}{*}{ Source of funding } & \multicolumn{7}{|c|}{ Allocation of R\&D spending by sector performing it } \\
\hline & \multicolumn{2}{|c|}{$\begin{array}{l}\text { Share of total R\&D } \\
\text { spending }\end{array}$} & \multicolumn{2}{|c|}{ Government } & Universities & $\begin{array}{l}\text { Business } \\
\text { enterprises }\end{array}$ & Total \\
\hline Government $^{1}$ & \multicolumn{2}{|c|}{23.3} & \multicolumn{2}{|l|}{51.1} & 31.6 & 17.3 & 100.0 \\
\hline Universities & \multicolumn{2}{|l|}{0.7} & \multicolumn{2}{|c|}{3.6} & 92.8 & 3.6 & 100.0 \\
\hline Business enterprises & \multicolumn{2}{|l|}{75.3} & \multicolumn{2}{|c|}{0.8} & 1.3 & 97.9 & 100.0 \\
\hline Foreign sources & \multicolumn{2}{|l|}{0.7} & \multicolumn{2}{|c|}{28.1} & 9.2 & 62.7 & 100.0 \\
\hline \multicolumn{8}{|c|}{ B. Sector performing $R \& D$} \\
\hline \multirow[b]{2}{*}{ Sector performing R\&D } & \multicolumn{7}{|c|}{ Funding source for R\&D performed } \\
\hline & $\begin{array}{c}\text { Share of total } \\
\text { R\&D } \\
\text { performed }\end{array}$ & Go & ernment & Universities & $\begin{array}{l}\text { Business } \\
\text { enterprises }\end{array}$ & $\begin{array}{l}\text { Foreign } \\
\text { sources }\end{array}$ & Total \\
\hline Government $^{1}$ & 12.7 & & 93.6 & 0.2 & 4.7 & 1.6 & 100.0 \\
\hline Universities & 9.0 & & 81.3 & 6.7 & 11.2 & 0.7 & 100.0 \\
\hline Business enterprises & 78.2 & & 5.2 & 0.0 & 94.2 & 0.6 & 100.0 \\
\hline
\end{tabular}

1. Includes private non-profit institutes.

Source: OECD R\&D Statistics Database (http://oecd.org/innovation/inno/researchanddevelopmentstatisticsrds.htm).

The share of high school graduates advancing to tertiary education fell to $71 \%$ in 2013 . Moreover, the number of high school graduates will fall below the current admission quotas for tertiary institutions by 2020. Korea has too many tertiary institutions and those outside of Seoul struggle to fill their student quotas (OECD, 2009). Most institutions run operating deficits. It is essential, therefore, to consolidate the tertiary sector while raising quality. However, only six of Korea's approximately 200 universities have been closed since 2010. Enhancing the autonomy of tertiary institutions and promoting transparency and competition would help ensure that consolidation at the university level is accomplished through the closure of poorly-performing institutions. First, it is important to cut public funding of poorly-performing 
tertiary institutions, ensure a well-functioning accreditation system and enhance transparency about each institution's educational performance to promote consolidation. Second, the top-down system of regulation should be relaxed to encourage autonomy, innovation and flexibility. In particular, the government should eliminate the quotas that it imposes on each tertiary institution's student enrolment to facilitate consolidation (Jones, 2013).

Figure 14. An overview of Korea's national science and innovation system

Normalised index of performance relative to the median values in the OECD area in 2014 (Index median=100)

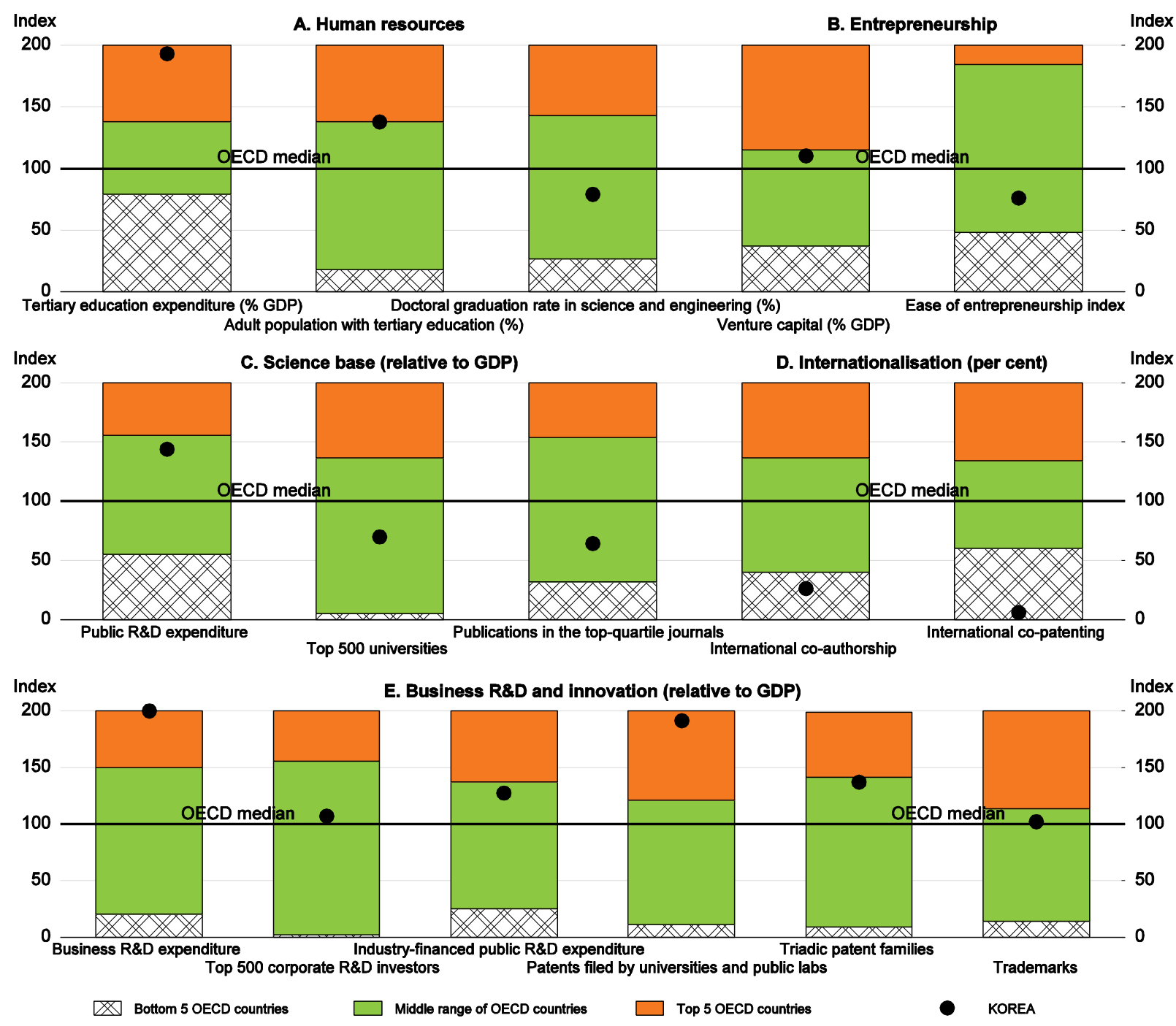

Note: Normalised index of performance relative to the median values in the OECD area, which are set at 100. The top performer is set at 200 and the lowest at zero. The fifth-highest performer in the case of the "Top 500 universities" had a score of 137 relative to the OECD median, while the fifth lowest had a score of 5 . Korea, with a score of 70 , was in the middle range.

Source: OECD (2014c).

One reason why Korea produces few high-impact publications is because public research has been skewed towards applied and development-oriented research performed largely in GRIs. With the government committed to expand public R\&D to 92 trillion KRW (6.2\% of 2014 GDP) over five years, it is important to take steps to upgrade the efficiency of public R\&D investment by improving the evaluation of the performance of GRIs and national R\&D programmes. In 2011, there were 41619 governmentfunded R\&D projects, with total spending exceeding $1 \%$ of GDP. Of the total, more than a third went to 
the 27 GRIs, whose performance has been criticised (OECD, 2014a). GRIs have failed to meet privatesector expectations. It is important to clearly define the role of GRIs and improve their steering and incentives. GRIs may have a role to play with SMEs and the service sector, where R\&D is low.

Links between universities, GRIs and enterprises have traditionally been underdeveloped, and efforts are required to strengthen these relationships to improve technology transfer and commercialisation. For example, $97.9 \%$ of the $\mathrm{R} \& \mathrm{D}$ financed by enterprises was performed in the business sector in 2014, compared to only $1.3 \%$ at universities and $0.8 \%$ at GRIs, indicating weak linkages in the R\&D system. Although Technology Licensing Offices have increased the transfer of technology from the 30 major universities to industry, only 5\% of company patents cite university-developed technology, compared to around 9\% in Canada and the United States (OECD, 2014a). Increased emphasis on university research should be accompanied by greater university-business co-operation in a range of areas, including accreditation and curriculum (Jones, 2013).

Establishing an eco-system for co-operation among GRIs, universities and industry to promote wider use of public R\&D results is essential. Current initiatives, such as the programme to support exchanges of researchers between universities and GRIs, and the plan to establish several joint industry-university-GRI R\&D centres, are helpful in this regard. A fundamental goal should be to reorient GRIs' research towards areas where it can be productively used, particularly by SMEs and service-sector firms, as noted above.

\section{Expanding international collaboration in research and patenting}

Better integration with global science and innovation networks is a priority. Only $0.7 \%$ of R\&D performed in Korea was funded from abroad (Table 8). Korea's levels of international co-authorship and co-patenting are among the lowest in the OECD (Figure 14, Panel D). A traditionally strong focus on applied research performed largely in GRIs and the weak internationalisation of Korean universities explain the low level of international co-authorship. The low level of patent applications with foreign coinventors is partly due to Korea's conglomerate industrial structure, which tends to retain technology development within the group.

As Korea looks to build its fundamental research capacity and its firms work increasingly at technological frontiers, it needs to better tap into global science and innovation networks. Such an approach allows access to broader pools of knowledge at lower costs and allows firms to share risk (OECD, 2015d). The government has developed a plan to promote such co-operation, emphasising the creation of a global network of overseas science, technology and innovation outposts, expansion of S\&T official development assistance, promotion of international joint $R \& D$, and sharing of large $R \& D$ facilities. These measures could be usefully complemented by reducing barriers to trade and investment, which would facilitate foreign investment in $\mathrm{R} \& \mathrm{D}$ and help Korea connect to global science and innovation networks.

\section{Ensuring the effectiveness of government support}

Direct government support for R\&D creates risks associated with "picking winners". Given such risks, direct R\&D support in the OECD area has fallen in recent decades. In Korea, direct support for business R\&D is one of the highest in the OECD at $0.2 \%$ of GDP (OECD, 2015d). To prevent wasteful outlays, the allocation of direct support should be based on a competitive, objective and transparent selection process. Although this boosts administrative and compliance costs, subsidies allocated on a selective basis have a larger impact on firm productivity than automatic subsidies (Colombo et al., 2011), in part because they send a quality signal to private firms receiving public R\&D support (Kleer, 2010). In Korea, 34 ministries and agencies run R\&D programmes, each with their own selection process. Finally, it is essential to constantly evaluate the effectiveness of R\&D policies to ensure good value for money. 


\section{Going digital to boost productivity}

Building on its position as a world-leader in the provision of ICT goods and benefiting from extensive broadband deployment, Korea has great scope to harness the potential of the digital economy to drive productivity. Indeed, Korea has the highest number of broadband subscriptions (relative to population) with $100 \mathrm{Mbps}$ or higher download speeds. In terms of total fixed broadband penetration, Korea ranks fifth among OECD countries. Korea's creative economy initiative calls for "combining science, technology and ICT to energise existing industries" and "developing new industries based on software and the Internet" (2014 OECD Economic Survey of Korea). Improved access to data and greater use of data can lead to greater economic value creation.

One of the goals of the creative economy strategy is to increase ICT adoption within SMEs. In Korea, only $15.3 \%$ of firms were engaged in sales via e-commerce in 2013, below the OECD average of $20.8 \%$. While $34 \%$ of large companies (more than 250 employees) sold online, this was the case for only $15 \%$ of smaller companies (10-49 employees) (OECD, 2015d). In addition, cloud computing deserves special attention, as it can transform business operations by providing easier, more flexible and on-demand access to applications and computing power. The potential is particularly great for smaller firms. In 2014, more than $22 \%$ of businesses used cloud computing services in the OECD area. In Korea, however, the use of cloud computing is relatively low, particularly among small companies (Figure 15). The Internet of Things (IoT) is another area where Korea has great potential. In sum, a more pervasive and intensive use of digital technologies can increase efficiency in SMEs and improve their capacity to adapt to rapidly changing markets, thereby reducing the large labour productivity gap relative to big enterprises (OECD, 2015a).

\section{Developing human capital to raise productivity}

In the OECD PISA tests on reading, science and mathematics, an international comparison of 15 yearolds across countries, Korea is consistently near the top. Moreover, the performance of young adults (1634 ) in the OECD Survey of Adult Skills (PIAAC) is also outstanding (OECD, 2013c), as the share of youth with tertiary education is the highest in the OECD. However, the gap between young adults and older persons is the largest in the OECD in terms of tertiary graduation rates and skill levels (Jones and Fukawa, 2016). For the 35-44 age cohort, literacy proficiency is close to the OECD average, but then drops well below it from age 45 (Figure 16). Adult education and learning has been shown to have a large impact on literacy proficiency in Korea (OECD, 2015e). However, the participation rate in education and learning is lowest among the adults with the lowest skill levels, suggesting that Korea could reap significant gains by expanding such opportunities.

The low skill level of older workers holds back productivity in services and SMEs, given that once workers leave their careers at around age 50, a large share ends up in SMEs or in self-employment in the service sector. Indeed, $28 \%$ of those employed in 2011 were self-employed, one of the highest rates in the OECD and well above the average of $16 \%$. Among the under-age 30 cohort, the self-employment rate is only $5 \%$ but for those over 50 , it is $34 \%$.

Korea is developing National Competency Standards (NCS), which identify the knowledge, skills and attitudes necessary to perform tasks by sector and level of industry. Thus far, 847 out of 887 NCSs have been completed and the standards will be continuously updated to ensure that they remain relevant. The NCS provides a strong basis for education and training, as junior colleges and vocational high schools are being supported in adopting NCS-based curricula. NCS have a key role to play in reducing the overemphasis on higher education (Jones, 2013), while providing a strong foundation for adult education and lifelong learning. Achieving these goals requires a whole-of-government approach that is explained in the OECD Skills Strategy for Korea (OECD, 2015e). 
Figure 15. The use of cloud computing services is low in Korea

As a percentage of enterprises in each employment size class in 2014

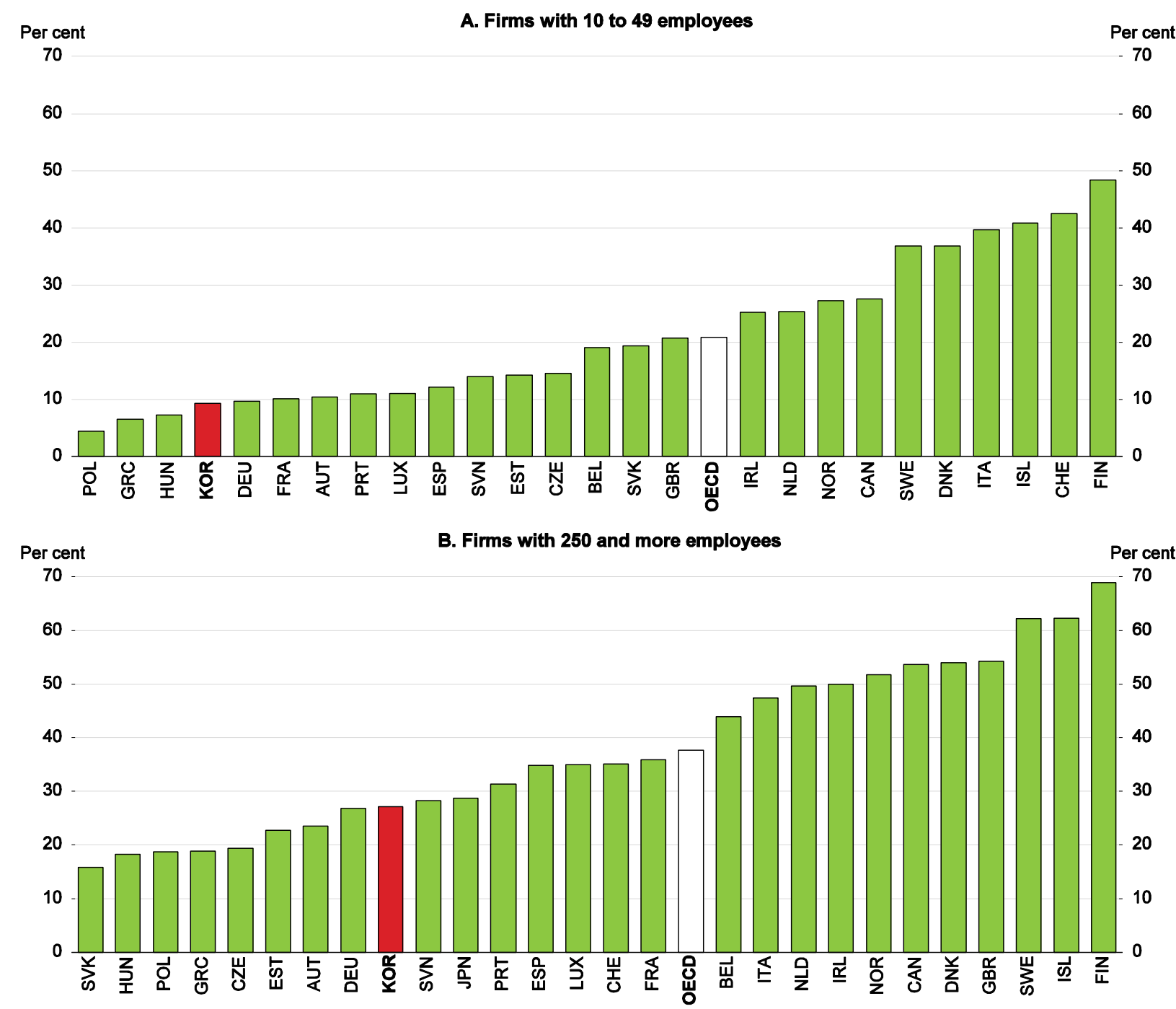

Source: OECD (2015b).

Another educational priority is developing skills necessary for entrepreneurship. The share of Koreans with a favourable view of entrepreneurship is one of the lowest in the OECD (Figure 17). In Korea, entrepreneurship is most often driven by necessity, reflecting the high share of older workers starting businesses compared to youth. Indeed, the number of start-ups founded by adults under the age of 30 accounted for less than $10 \%$ of all start-ups in Korea in 2014. Young people interested in starting new businesses often have to overcome the negative perception of parents, teachers and society in general, not to mention an adverse business and financial environment. Moreover, survey data indicate that Koreans perceive fewer entrepreneurial opportunities and are more fearful of failure. Government initiatives to make it easier for failed entrepreneurs to obtain loans should help reduce the fear of failure. 
Figure 16. Skills of older workers in Korea are well below the OECD average

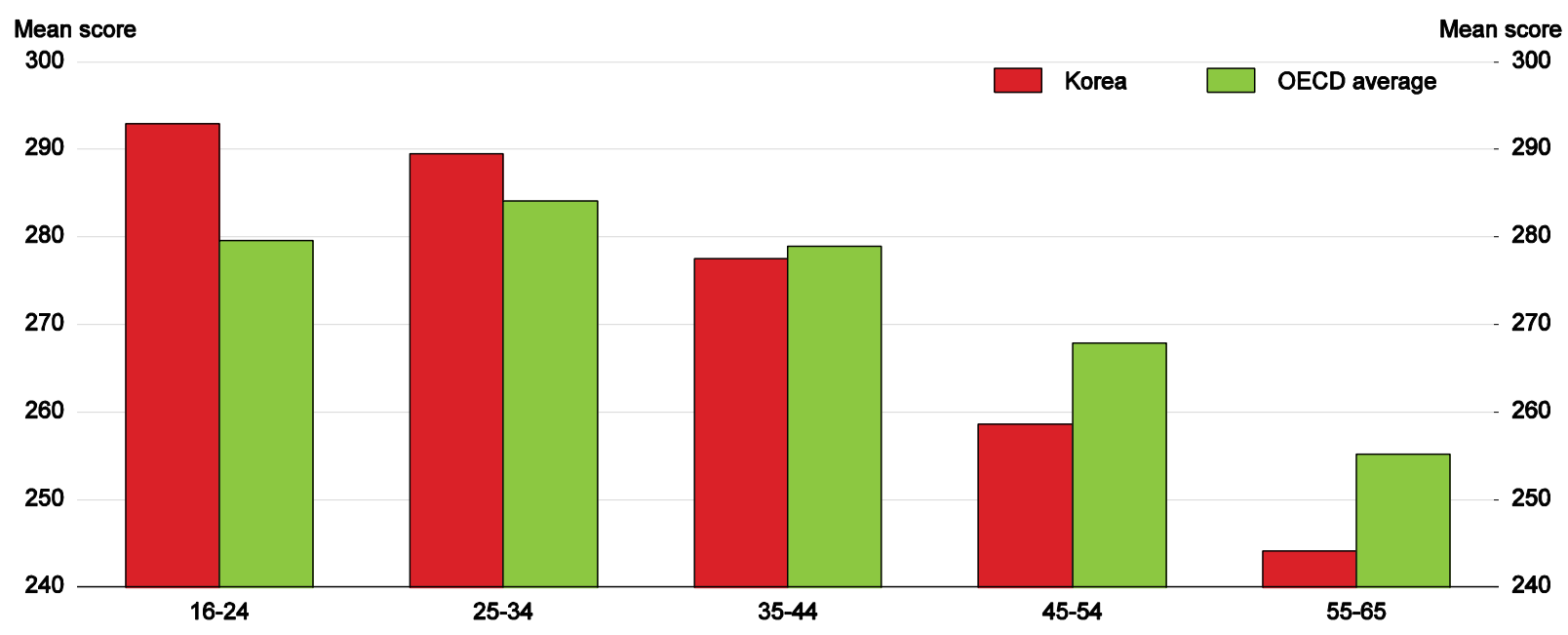

Source: OECD (2013c).

In addition, Koreans find themselves less capable of becoming entrepreneurs than in most other countries; only $40 \%$ of adults agree that school education provided the skills and know-how needed to run a business (OECD, 2015e). Schools need to provide more practical training for potential entrepreneurs in areas such as business management, negotiation and marketing skills, financing skills and an understanding of legal and regulatory frameworks. Korea is moving rapidly to address such weakness: from 2018, primary, middle and high schools will provide mandatory entrepreneurship education (M. Lee, 2015).

\section{Figure 17. Entrepreneurship education is needed in Korea to improve the image and skills of entrepreneurs}

Share of respondents with a broadly favourable image of entrepreneurs

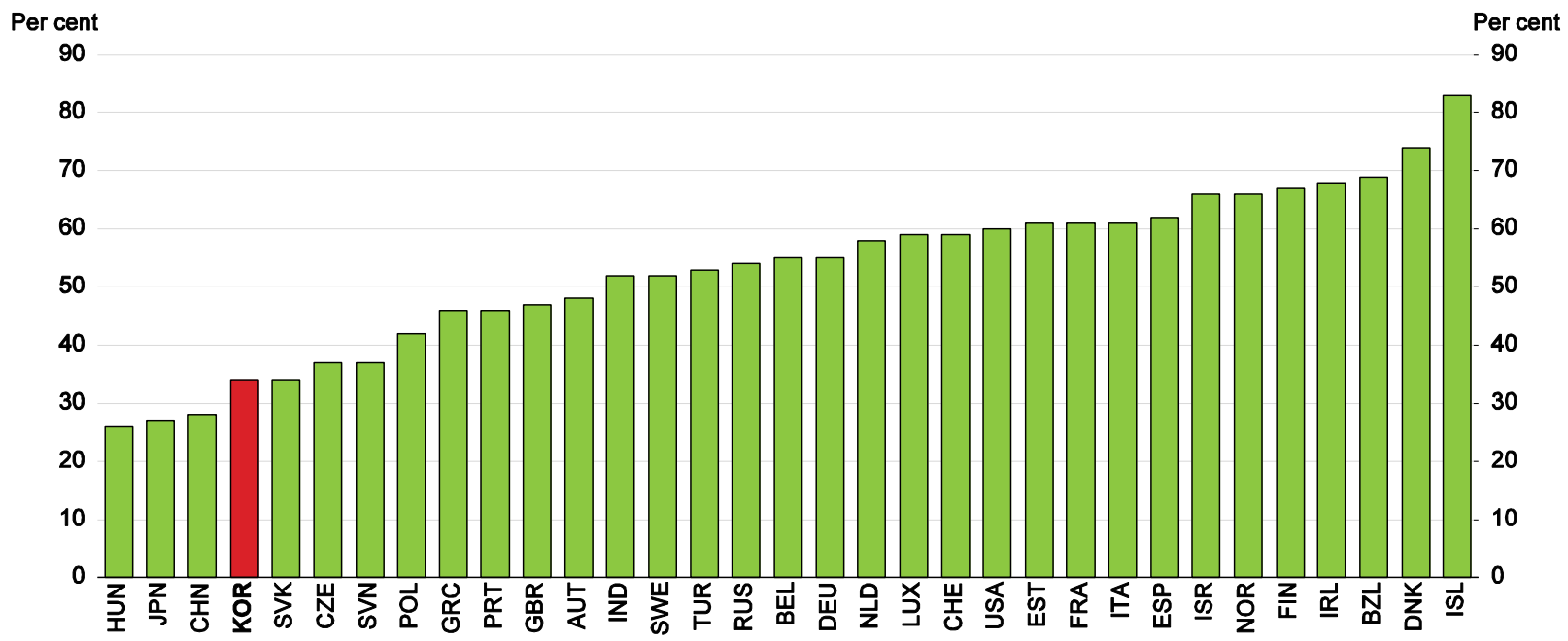

Source: OECD (2013a).

\section{Policies to promote SMEs' productivity through innovation}

The 2013 Creative Economy Action Plan aims to expand the role of SMEs. The government has long provided large-scale support to SMEs through public funds, credit guarantees and around 1300 programmes. In addition, SMEs are assisted through: $i$ ) preferential treatment in public procurement; ii) lower tax rates at both the central and local government levels; iii) protection from the Korea Fair Trade 
Commission against market power abuses; $i v$ ) the right to hire foreign workers; and $v$ ) discounted prices for water and electricity. Despite such support, SME performance has deteriorated relative to large firms.

\section{SME policies promote the survival of low-productivity small firms}

There is considerable evidence that government support does not improve SME performance. A comparison of firms that received public financial support over 2003-09 with firms that did not found little difference in the performance of the two groups in terms of profitability and growth (KDI et al., 2011). Another study found that SMEs that received government support had higher survival rates in 2011 and, in some cases, higher sales and employment than firms not receiving support. However, their profits and wages did not improve and in some cases fell. Most importantly, TFP in firms receiving support was significantly less on average than in firms not receiving public support, suggesting that public subsidies fail to boost productivity (Chang et al., 2014). Meanwhile, another study found that SMEs receiving public support recorded improved financial performance such as higher revenue and operating profit ratios than firms without support (Nam et al., 2015).

Government policies that increase survival rates of low-productivity firms are detrimental to long-run efficiency. Focusing on the survival of existing SMEs works against market forces, which can lead to better outcomes. Slower output growth in 2008-09 contributed to the exit of 25236 firms (Table 9). The more efficient firms (32 964 in total), which continued in business, expanded by taking over the resources of exiting firms. In addition, new firms entered the market, resulting in a slight net increase in the number of firms. Consqeuently, there were large increases in sales and profits over 2008-11.

Table 9. Creative destruction in Korea's manufacturing and mining sectors

\begin{tabular}{|c|c|c|c|c|c|c|c|}
\hline \multicolumn{4}{|c|}{2008} & \multicolumn{3}{|c|}{2011} & \multirow[b]{2}{*}{$\begin{array}{c}2008-11 \\
\text { percentage } \\
\text { change in } \\
\text { total }\end{array}$} \\
\hline & $\begin{array}{c}\text { Firms that } \\
\text { continued } \\
\text { through } \\
2008-11\end{array}$ & $\begin{array}{c}\text { Firms that } \\
\text { exited } \\
\text { between } \\
2009-11 \\
\end{array}$ & Total & $\begin{array}{c}\text { Firms that } \\
\text { continued } \\
\text { through } \\
2008-11\end{array}$ & $\begin{array}{c}\text { Firms that } \\
\text { entered } \\
\text { between } \\
2009-11\end{array}$ & Total & \\
\hline $\begin{array}{l}\text { Number of } \\
\text { establishments }\end{array}$ & 32964 & 25236 & 58200 & 32964 & 25419 & 58383 & 0.3 \\
\hline Sales $^{1}$ & 792.8 & 419.7 & 1209.5 & 1144.7 & 296.7 & 1441.5 & 19.2 \\
\hline Profits & 69.9 & 48.1 & 118.0 & 108.5 & 23.1 & 131.6 & 11.5 \\
\hline Employment $^{2}$ & 1578.2 & 839.1 & 2417.3 & 1761.6 & 766.7 & 2528.3 & 4.6 \\
\hline Payment & 55.8 & 25.8 & 81.7 & 70.2 & 19.8 & 90.0 & 10.2 \\
\hline Average wage $^{3}$ & 35.4 & 30.8 & 33.8 & 39.9 & 25.8 & 35.6 & 5.4 \\
\hline
\end{tabular}

1. Trillion KRW.

2. Thousand workers.

3. Million KRW.

Source: Chang (2015).

The emphasis on the survival of exisiting firms reflects the role of SME policy as a social safety net. The early departure of employees at firms - at age 53 on average - prompts a large number to invest their retirement allowance in small firms to provide income. Policy should instead focus on increasing productivity in SMEs to promote long-term growth (Chang, 2016), while reforming the labour market to extend the careers of workers and developing a social saftey net (Jones and Fukawa, 2016). This requires an SME policy that corrects market failures, such as information asymmetries and abuses of market power (Chang, 2015). Achieving efficiency goals would also be promoted through other reforms to SME policy. In 2013, 14 central government ministries ran 201 programmes, while the 16 provincial governments and 130 SME-related organisations administered another 1101 programmes, resulting in duplication and waste. First, a policy evaluation and feedback system is needed to improve the efficiency of SME programmes. Second, policy co-ordination is necessary to reduce the duplication of programmes. While 
the Small and Medium Business Administration plays the role of control tower, it is not impartial as it runs many programmes of its own. A higher level body should instead play this role. A government task force abolished 10 projects in 2014-15 and its efforts should be accelerated. Third, it is necessary to set limits on the number, duration and size of government programmes to encourage the long-run self-reliance of SMEs. The generosity of support to SMEs should be reduced.

\section{Policies to improve SME financing}

The government role is expanding, while problems remain in private-sector lending

SME policy is particularly focused on providing financing, given market failures that limit marketbased funding (Jones and Kim, 2014). Financing of SMEs can be classified into three categories: indirect financing from financial institutions; direct financing from capital markets; and government financing (Table 10). Government financing increased $42 \%$ in 2009, in the wake of the 2008 financial crisis, boosting it to $11.4 \%$ of total SME financing, from $8.7 \%$ in 2008 . Its share has continued to rise, reaching $14.9 \%$ in 2013 (Figure 18). This amounts to around 6\% of GDP, which is high compared to other countries. Indeed, government guarantees amounted to 5\% of GDP in 2014, one of the highest figures in the OECD (Panel C).

Table 10. SME reliance on government financing has increased since 2009

In trillion KRW in the top row for each year; as a percentage of total borrowing in the bottom row

\begin{tabular}{|c|c|c|c|c|c|c|c|c|c|c|c|c|}
\hline & \multicolumn{3}{|c|}{ Indirect financing } & \multicolumn{4}{|c|}{ Direct financing } & \multicolumn{4}{|c|}{ Government financing } & \multirow[b]{2}{*}{ Total } \\
\hline & $\begin{array}{l}\text { Bank } \\
\text { loans }\end{array}$ & $\begin{array}{c}\text { Non- } \\
\text { bank } \\
\text { loans }\end{array}$ & Sub-total $\left.\right|^{3}$ & Bonds $^{4}$ & Stocks ${ }^{5}$ & $\begin{array}{l}\text { Venture } \\
\text { capital }\end{array}$ & $\begin{array}{l}\text { Sub- } \\
\text { total }\end{array}$ & $\begin{array}{c}\text { On- } \\
\text { lending }\end{array}$ & $\begin{array}{l}\text { Policy } \\
\text { funds }\end{array}$ & $\begin{array}{l}\text { Guarantee } \\
\text { balance }^{8}\end{array}$ & $\begin{array}{l}\text { Sub- } \\
\text { total }\end{array}$ & \\
\hline \multirow{2}{*}{2005} & 256.5 & 82.5 & 293.6 & 0.3 & 3.0 & 3.4 & 6.7 & - & 3.2 & 45.4 & 48.6 & 348.8 \\
\hline & 73.5 & 23.7 & 84.2 & 0.1 & 0.9 & 1.0 & 1.9 & 0.0 & 0.9 & 13.0 & 13.9 & 100.0 \\
\hline \multirow{2}{*}{2007} & 369.9 & 101.4 & 427.0 & 0.8 & 4.6 & 3.6 & 8.9 & - & 2.8 & 44.4 & 47.2 & 483.1 \\
\hline & 76.6 & 21.0 & 88.4 & 0.2 & 1.0 & 0.7 & 1.8 & 0.0 & 0.6 & 9.2 & 9.8 & 100.0 \\
\hline \multirow{2}{*}{2009} & 443.4 & 121.8 & 497.5 & 1.1 & 4.5 & 3.9 & 9.5 & 0.2 & 5.9 & 67.7 & 73.8 & 580.8 \\
\hline & 76.3 & 21.0 & 85.7 & 0.2 & 0.8 & 0.7 & 1.6 & 0.0 & 1.0 & 11.7 & 12.7 & 100.0 \\
\hline \multirow{2}{*}{2011} & 454.9 & 97.5 & 482.5 & 0.9 & 1.8 & 4.8 & 7.6 & 4.3 & 3.4 & 69.9 & 77.6 & 567.7 \\
\hline & 80.1 & 17.2 & 85.0 & 0.2 & 0.3 & 0.9 & 1.3 & 0.8 & 0.6 & 12.3 & 13.7 & 100.0 \\
\hline \multirow{2}{*}{2013} & 489.2 & - & 489.2 & 0.1 & 0.8 & 6.4 & 7.2 & 6.7 & 4.9 & 75.5 & 87.1 & 583.5 \\
\hline & 83.8 & 0.0 & 83.8 & 0.0 & 0.1 & 1.1 & 1.2 & 1.1 & 0.8 & 12.9 & 14.9 & 100.0 \\
\hline
\end{tabular}

$1 \quad$ Includes general banks and specialised banks.

2. Includes loans of mutual savings banks, credit associations, mutual finance companies and Saemaeul finance firms. No data are available for 2013.

3. The sub-total excludes the government's guarantee balance, except in 2013 , as the share of guarantees applied to bank loans is unkown.

4. Excludes ABS and financial bonds.

5. Stock issuance through IPOs and paid-in capital increases.

6. A public institution (Korea Finance Corporation) provides $40 \%$ of the loan to financial institutions On-lending is the Korea Finance Company's policy loan balance.

7. The balance of the Small and Medium Business Associations' policy loans.

8. The sum of the guarantee balances in the Korea Credit Guarantee Fund (KODIT), the Korea Technology Finance Corporation (KIBO), and local KODIT.

Source: Koo et al. (2015).

However, public support through direct credit and guarantees to SMEs has many negative effects:

- It hinders the development of the market by reducing financial institutions' incentives to develop their credit evaluation and risk management skills for SME lending (Sohn and Kim, 2013). 
Figure 18. Public financing for SMEs is high compared to other major advanced countries

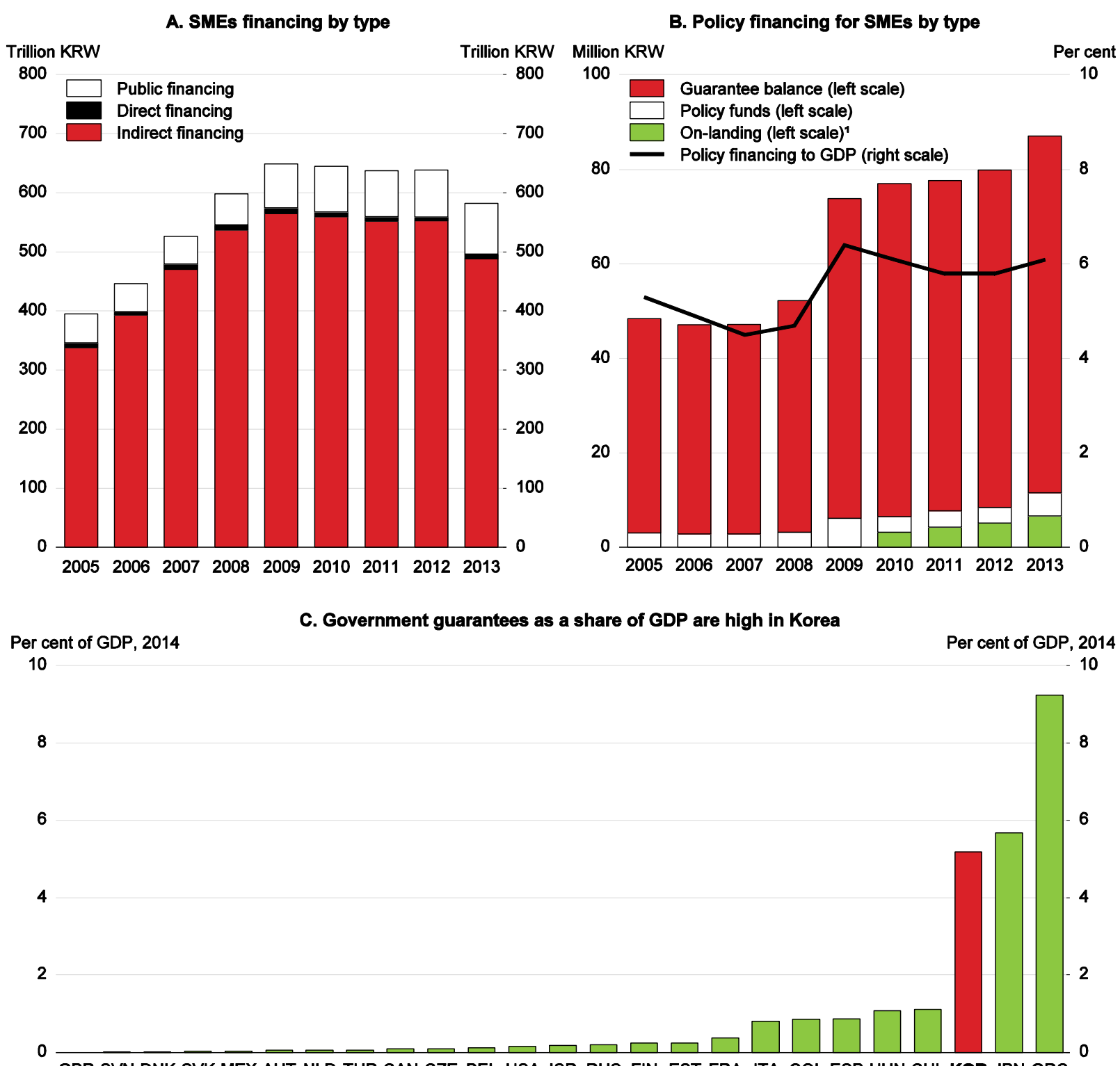

GBR SVN DNK SVK MEX AUT NLD TUR CAN CZE BEL USA ISR RUS FIN EST FRA ITA COL ESP HUN CHL KOR JPN GRC

1. A public institution (Korea Finance Corporation) provides $40 \%$ of the loan to financial institutions, which supply the rest of the loan. Source: Small and Medium Business Administration; Korea Finance Corporation; Statistics Korea; OECD (2016a).

- The coverage ratio of guarantees was set at $85 \%$, compared to $75-80 \%$ in most OECD countries, until November 2015. The high ratio discouraged financial institutions from actively monitoring the credit risk of outstanding loans.

- Government intervention often supports non-viable SMEs. Once loans are given to a firm, financial institutions and credit guarantee providers share a common interest in its survival, as a default would result in losses for both of them. To delay or prevent such a loss, they may continue to support the firm, a phenomenon referred to as "evergreening", which facilitates the survival of "zombie firms", and lowers Korea's growth potential (Box 3).

- High levels of government support and its long duration discourage companies from expanding and thereby achieving economies of scale (the so-called "Peter Pan syndrome"). Only $0.01 \%$ of small firms in 2011 had grown into mid-sized firms by 2014. 
- More than half of government guarantees were given to highly-rated companies more than ten years old. Moreover, a quarter of guarantees are for more than ten years. Such a composition crowds out support for start-ups and highly innovative young firms. The survival rate of new start-ups after three years is relatively low in Korea at 41.0\%, compared to other countries such as Austria (62.8\%), the United States (57.6\%), Israel (55.4\%) and Italy 54.8\% (FSC, 2015a).

In November 2015, the government announced policy directions for a new guarantee system (Table 11). The objective of reducing guarantees to mature SMEs to focus more on start-ups and early-stage SMEs, where the difficulty of securing market financing is greatest, is in line with past OECD recommendations (2014 OECD Economic Survey of Korea). However, the objective of reducing the burden of using guarantees and reviewing them every five to eight years rather than annually would seem to promote long-term guarantees. In addition, the new policy directions seem aimed at increasing the use of guarantees. For example, making credit guarantees more effective in promoting economic stability would suggest a large expansion from their already-high level. In particular, the new coverage ratio of guarantees is still relatively high, except for some mature SMEs. The high level discourages banks from actively monitoring credit risks. Rather than expanding guarantees, it is important to focus on developing the infrastructure for market-based SME financing, including the framework for credit evaluation.

Table 11. Basic policy direction to build a new guarantee system for SMEs

\begin{tabular}{|c|c|}
\hline Strategy & Projects \\
\hline $\begin{array}{l}\text { 1. Expand guarantee } \\
\text { support for start-ups and } \\
\text { SMEs at an early stage }\end{array}$ & $\begin{array}{l}\text { Expand efforts to discover and support SMEs at an early stage } \\
\text { Minimise the burden on SMEs of using guarantees by shifting from annual } \\
\text { inspections to once every 5-8 years and raising the guarantee rate to } 90 \% \\
\text { The requirement that firms have joint guarantors will be abolished for all firms } \\
\text { Diversify the funding path of start-ups and early-stage SMEs }\end{array}$ \\
\hline $\begin{array}{l}\text { 2. Streamline the usage } \\
\text { of guarantees by mature } \\
\text { SMEs }\end{array}$ & $\begin{array}{l}\text { Respond to the demand of mature SMEs for credit guarantees } \\
\text { Allow banks, rather than public agencies, to choose which firms receive guarantees } \\
\text { Set the guarantee ratio at } 50-85 \% \text { for mature firms } \\
\text { Support the establishment of an organisation in the public agencies providing } \\
\text { guarantees to support IPOs by mature SMEs }\end{array}$ \\
\hline $\begin{array}{l}\text { 3. Increase efficiency of } \\
\text { the guarantee supply } \\
\text { system }\end{array}$ & $\begin{array}{l}\text { Differentiate the roles of the different public credit guarantee agencies } \\
\text { Expand the guarantee system to make it more effective in stabilising the economy } \\
\text { Introduce a guarantee system specialised by the age of SMEs }{ }^{1}\end{array}$ \\
\hline
\end{tabular}

1. Until November 2015 , credit guarantees covered a uniform $85 \%$ of the value of the loan. A differentiated approach is now in place: i) start-up stage (100\% the first year, then $90 \%$; ii) growth stage (85\%); and iii) mature stage $(50-85 \%$, based on the credit rating).

Source: Financial Services Commission (2015a). 


\section{Box 3. Non-viable companies are a major concern in Korea}

The share of non-viable companies (often referred to as "zombie companies") - defined as those with negative operating profits over three years -- has increased steadily over the past decade, rising from $4.7 \%$ in 2003 to $11.1 \%$ in 2014 for SMEs (Figure 19). The share for large companies also increased and is now higher than that of SMEs, reflecting the slowdown in export growth and problems in a few major industries. The share of marginal companies in Korea is significantly higher than in major economies, including Japan (2\%), the euro area (4\%) and the United States $(7 \%)$. The number and share of marginal companies has risen despite a fall in the average amount of debt in large firms (Panel B).

Figure 19. The number of non-viable companies is increasing

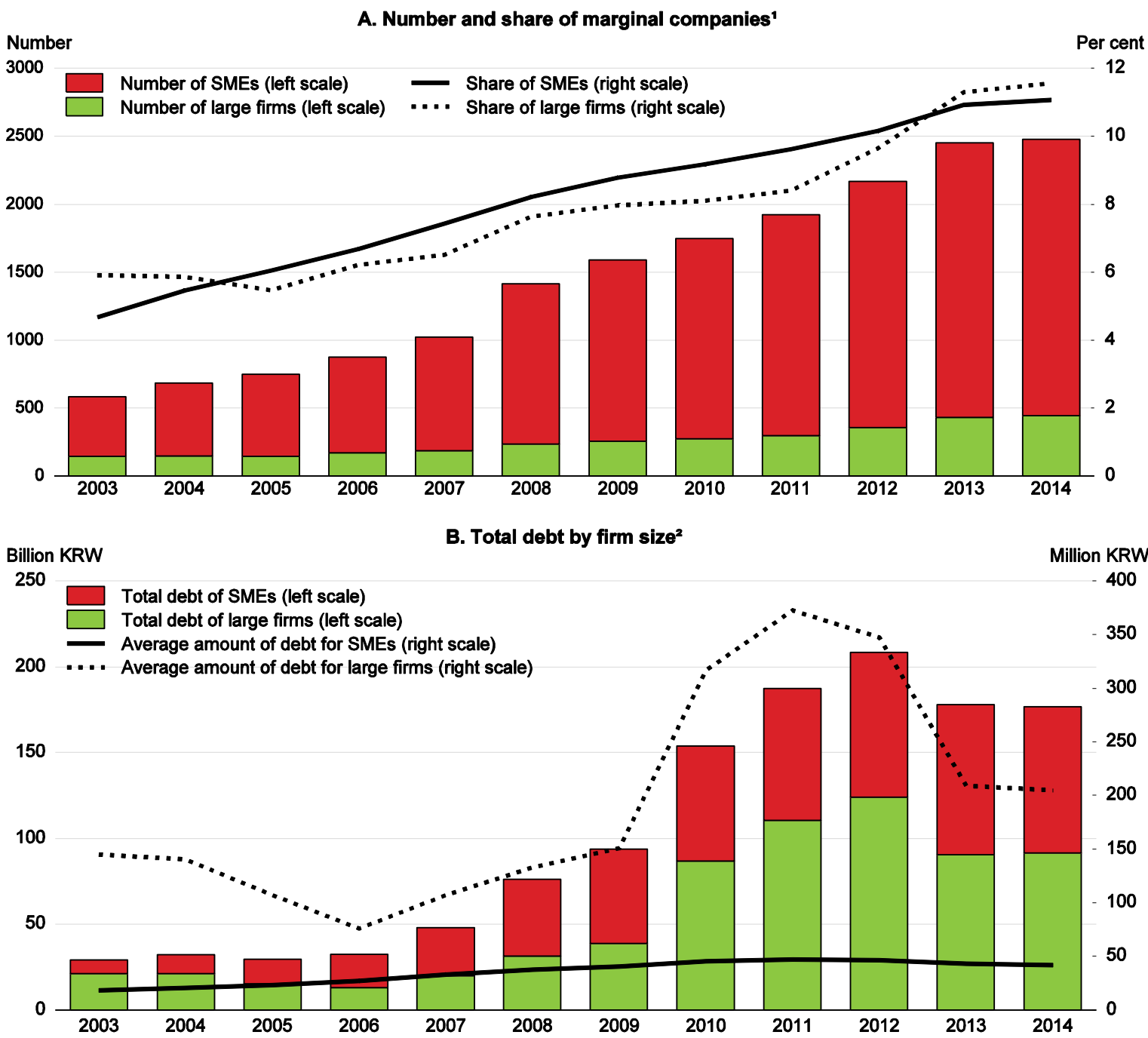

1. Number of companies with negative operating profits for at least three consecutive years. Data from the National Information and Credit Evaluation (NICE) and Korea Enterprise Data (KED) database.

2. Corporate debt is based on the total liabilities in the financial statements. Source: Shin (2015).

Non-viable companies' operating margins are smaller than average while their debt level is higher and has risen rapidly. The increasing concentration of bank lending on highly-rated SMEs (Table 12) has aggravated the shortage of funding for marginal firms (Bank of Korea, 2014). To ensure adequate start-up financing, a number of reforms are needed:

- The government's credit guarantee programme should focus on early-stage, innovative companies, in part by enhancing its capability to analyse technology. 
- Improve direct financing opportunities for start-ups and early-stage SMEs by developing capital markets, thereby reducing reliance on indirect financing.

- $\quad$ Promote continuous structural reform of marginal companies based on the credit assessment by creditor banks, rather than by government intervention. Pre-emptive corporate restructuring is more efficient than work-outs of failed firms.

Table 12. Lending to SMEs is increasingly backed by collateral and concentrated among highly-rated firms

\begin{tabular}{|c|c|c|c|}
\hline \multicolumn{4}{|c|}{ A. Lending to SMEs by type of loan } \\
\hline & $\begin{array}{c}\text { In per cent } \\
2009\end{array}$ & 2011 & $2013^{1}$ \\
\hline Credit loans $^{2}$ & 49.0 & 46.3 & 43.7 \\
\hline Collateralised loans ${ }^{3}$ & 37.5 & 40.6 & 43.1 \\
\hline Guaranteed by government & 13.5 & 13.1 & 13.2 \\
\hline Total & 100.0 & 100.0 & 100.0 \\
\hline \multicolumn{4}{|c|}{ B. The share of outstanding loans by SMEs' credit rating } \\
\hline \multicolumn{4}{|c|}{ In per cent } \\
\hline Credit ratings ${ }^{4}$ & 2009 & 2011 & $2013^{1}$ \\
\hline $1 \sim 3$ & 11.2 & 13.3 & 13.9 \\
\hline $4 \sim 5$ & 42.6 & 46.1 & 47.4 \\
\hline 6 & 19.9 & 15.9 & 15.0 \\
\hline $7 \sim 10$ & 4.9 & 4.6 & 4.1 \\
\hline Others & 21.5 & 20.1 & 19.6 \\
\hline Total & 100.0 & 100.0 & 100.0 \\
\hline
\end{tabular}

1. First quarter.

2. Loans from private financial institutions that are not guaranteed by a public institution or collateralised.

3. Loans backed by collateral, usually real estate.

4. The system is based on a ten-point scale with 1 representing the best credit rating.

Source: Financial Services Commission (2013).

The government directed banks to roll over SME loans automatically to prevent the default of sound SMEs in the wake of the 2008 global crisis (2014 OECD Economic Survey of Korea). The decline in the share of "credit loans" -- loans from private financial institutions that are not guaranteed by a public institution or collateralised - since 2009 was matched by a rise in the share of collateralised loans (Table 12), suggesting that financial institutions saw greater risk in SME lending. In addition, the share of SME lending to firms with high credit ratings (1-5) increased from $53.7 \%$ in 2009 to $61.3 \%$ in 2013 (Panel B). Financial institutions' heightened awareness of credit risk is a natural response to the sharp downturn in the wake of the 2008 crisis and subdued output growth since 2011. However, reduced lending to start-ups and early-stage SMEs, which typically have lower credit ratings, may slow innovation and productivity growth.

The government launched an initiative in July 2014 to promote loans based on technology to provide greater financing for start-ups without collateral. Four institutions, including the Korea Technology Finance Corporation (KTFC), were designated as Technology Credit Bureaus (TCBs), and launched a technology database service. According to a government survey, technology-based lending reached 51.5 trillion KRW (6.7\% of bank lending to the corporate sector) in the fourth quarter of 2015. The average interest rate on technology loans, at around 4\%, was lower than the overall average rate of $4.3 \%$. However, the technology system has some weaknesses. First, it focuses too much on existing firms wishing to expand, rather than on start-ups. Second, the time necessary to evaluate technology is too long, rising from 12.5 days in July 2014 to 45.7 days in March 2015. This boosts the cost of evaluation to one million KRW (around USD 875000 ), suggesting a need for new experts to analyse technology. Third, the procedures and documentation are not consistent. Fourth, different evaluation models and grading procedures between the four TCBs undermines the credibility of the system. 


\section{Developing venture capital and other forms of capital-market financing}

Problems faced by new start-ups and small firms in obtaining lending could be overcome by enhancing their access to capital markets. Investments are more suitable than loans for financing high-risk, high-return firms at an early stage. However, SME financing through the stock market fell from $1.5 \%$ of total SME financing in 2009 to $1.2 \%$ in 2013 (Table 10). Indeed, bond issuance by SMEs has practically ceased in the absence of a junk bond market. According to the FSS, SMEs' share of financing through bonds and equities fell from $9.0 \%$ in 2009 to $5.2 \%$ in 2015 (Table 13). A survey by a public-sector bank in 2015 reported that only $0.04 \%$ of SMEs have received financing through capital markets, primarily due to their inability to meet the requirements for issuing stocks and bonds, complicated issuance procedures and high issuance costs (Figure 20). In addition, some entrepreneurs prefer loans to receiving investments, as the processing time for a loan is shorter than the investment process and allows them to maintain more control over their firms. To weaken the preference for loans, government support for SMEs should shift away from direct lending and credit guarantees and put more weight on providing advice on financial, legal and taxation issues related to investment.

Table 13. The SMEs' share of financing through stocks and bonds has fallen sharply In per cent ${ }^{1}$

\begin{tabular}{lrrrc}
\hline & $\mathbf{2 0 0 9}$ & $\mathbf{2 0 1 1}$ & $\mathbf{2 0 1 3}$ & $\mathbf{2 0 1 5}$ \\
\hline Stocks & 39.1 & 13.9 & 15.3 & 28.9 \\
Bonds & 1.7 & 1.1 & 0.1 & 0.6 \\
Stocks and bonds & 9.0 & 3.3 & 1.8 & 5.2 \\
\hline
\end{tabular}

1. Excludes ABS, bank debentures and bank bonds. Source: Financial Supervisory Service (2016).

For SMEs that are able to access capital markets, the main methods are issuing new stocks and initial public offerings (IPOs) (Figure 20, Panel B). Nearly 98\% of such activities occurred in the KOSDAQ market, established in 1996 with the goal of facilitating IPOs. Issuance of corporate bonds (17.3\%) and venture capital $(7.9 \%)$ are used less by SMEs.

Figure 20. SMEs and capital markets
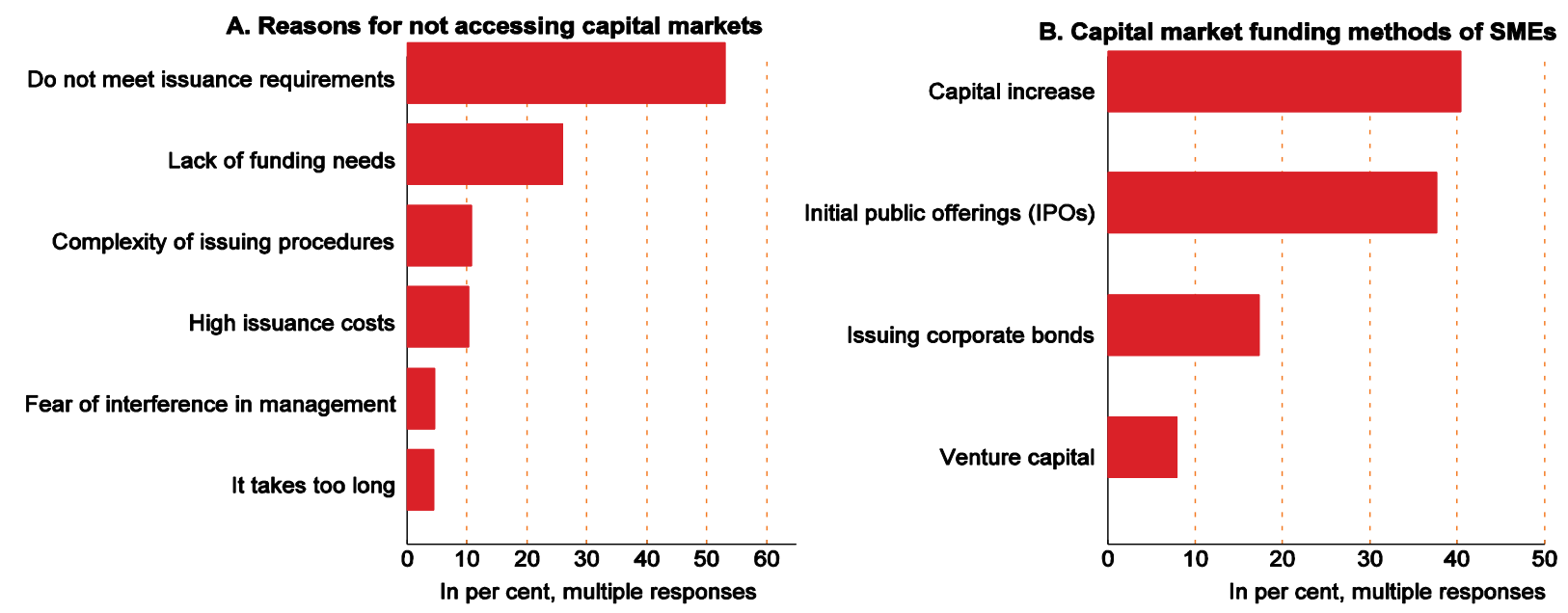

Source: Industrial Bank of Korea (2015). 


\section{Korea's creative economy initiative emphasises the role of venture capital}

The financing gap resulting from problems in indirect funding and traditional capital markets might be bridged by venture capitalists and business angels, who are willing to accept high risk for high returns. Such investors address information asymmetries by scrutinising new firms before providing capital and monitoring them afterwards. In Korea, the government jump-started the venture capital market in 1998 through a direct infusion of equity capital, generous tax incentives and credit guarantees. However, these policies fuelled a bubble in the KOSDAQ, the secondary stock market. With the collapse of the IT bubble, the KOSDAQ fell $90 \%$ from its peak. The contraction in venture capital investment continued through the 2008 global financial crisis (Figure 21).

Figure 21. Venture capital investment has been increasing since 2011

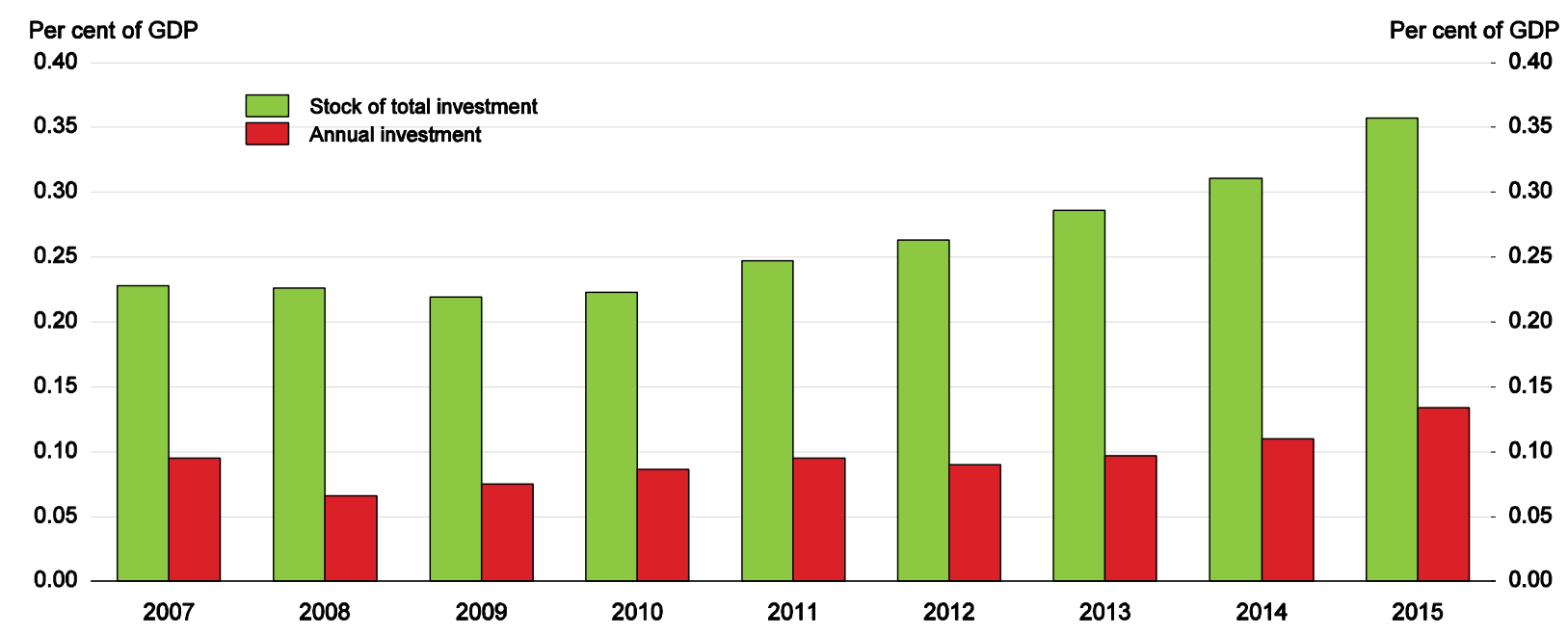

Source: Korea Venture Capital Association.

However, venture capital investment is increasing, strengthened by the government's 2013 "Measures to improve the venture start-up ecosystem" (2014 OECD Economic Survey of Korea). The stock of venture capital investment rose from $0.24 \%$ of GDP in 2010 to $0.35 \%$ in 2015 (Figure 21), while the number of venture investment companies increased from 110 in 2010 to 124 in 2015. A growing share of venture capital investment is in new fields, such as bio-technology, culture and services (Table 14). The enthusiasm over venture capital is reflected in a jump in the number of entrepreneurship clubs in universities from fewer than 2000 in 2013 to nearly 3000 in 2014. Rising venture capital investment led to a parallel increase in the number of "venture businesses" from 24645 in 2010 to 31260 in 2015 . However, less than 1000 of these firms have received venture capital investment (Lee, 2016). The remainder were designated based on government evaluation of their technology, thereby qualifying for preferential tax treatment.

Table 14. Venture capital is increasing in new sectors

Percentage of total venture capital investment

\begin{tabular}{cccccccc}
\hline & Telecommunications & Manufacturing & Bio-tech & Culture & Other services & Other & Total \\
\hline 2013 & 35 & 23 & 11 & 21 & 8 & 3 & 100 \\
2014 & 26 & 14 & 18 & 27 & 12 & 2 & 100 \\
\hline
\end{tabular}

Source: FSC (2015c). 


\section{Making venture capital investment a driver of innovation}

Despite the upward trend, venture investment accounted for only 1.1\% of SME financing in 2013 (Table 10). Establishing a vibrant venture capital market requires addressing a number of challenges.

\section{Increasing the focus on start-ups and firms at an early stage of development}

Venture capital investment is not sufficiently focused on start-ups and early-stage firms; $68.9 \%$ of the total in 2015 was invested in firms more than three years old and $26.7 \%$ was in firms that are more than seven years old (Figure 22). Firms less than three years old thus received less than a third of the investment, but accounted for $47.2 \%$ of the companies receiving investment. However, for firms more than seven years old, investment per firm is 2.3 times larger than in firms in their initial stages (Panel B). The concentration of venture capital in older firms creates a risk for young firms that is referred to as "Death Valley", in which many start-ups fail to survive despite their success in developing technology.

Figure 22. Venture capital investment is overly focused on mature firms

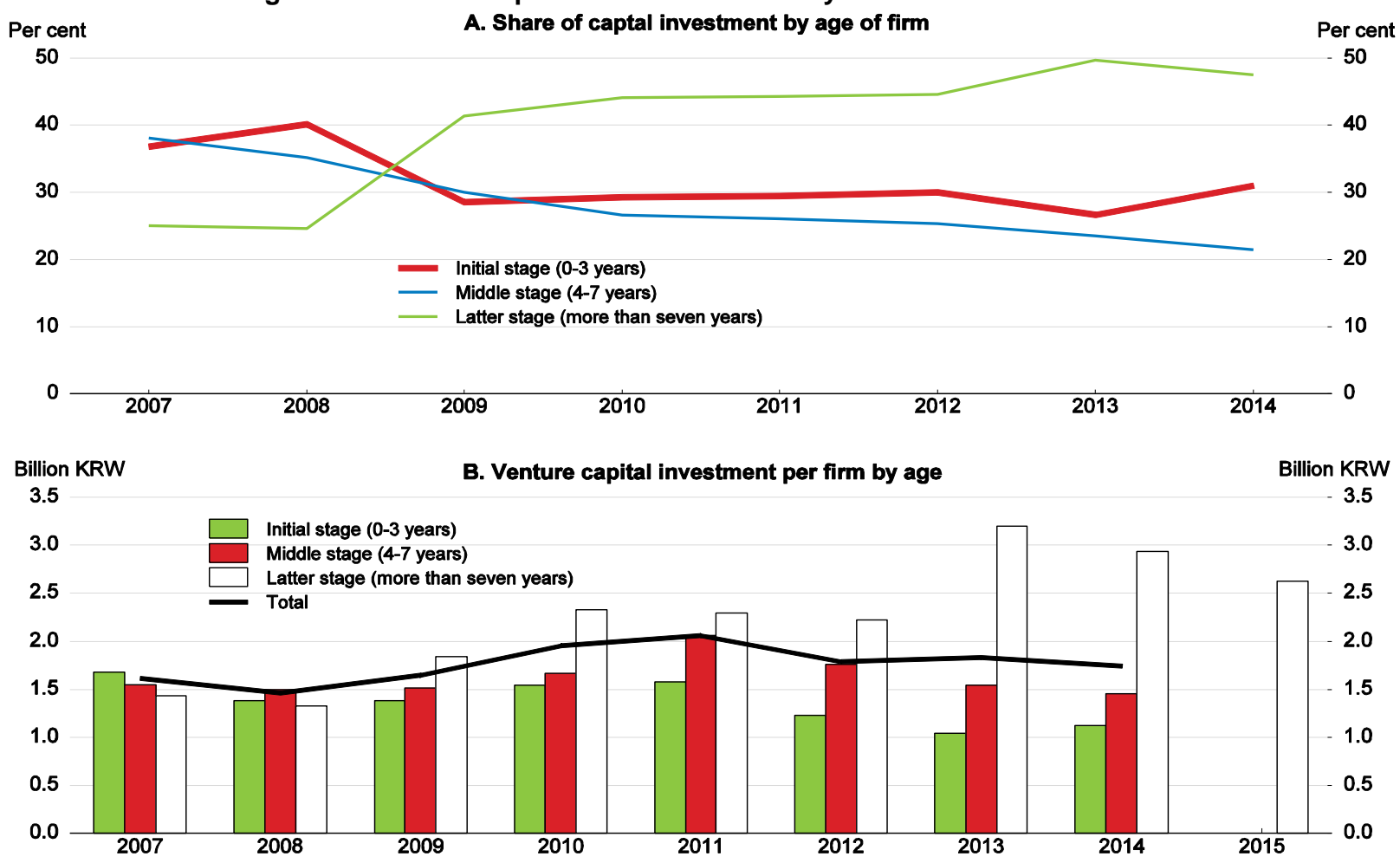

Source: Korea Venture Captital Association.

\section{Enabling venture capitalists to recover their investments}

The biggest obstacle to expanding Korea's venture capital investment system is the difficulty that venture capitalists face in recovering their investments. The concentration of venture capitalist investment in older firms reflects the fact that investors find it easier to recover their investments in older firms that are preparing for an IPO in the KOSDAQ market. Given the listing requirements, which include sales and total capital, the time required for a start-up to become eligible for listing was 12.2 years on average in 2015 . IPOs play a particularly important role in enabling venture capitalists to recover their investments, given that M\&As, which account for about $80 \%$ of the paybacks in the United States, are virtually non-existent in Korea. Expanding the M\&A markets, combined with other measures to improve capital markets (Box 4), is essential to promote venture capital investment in Korea. 


\section{Box 4. Expanding the role of capital markets}

In 2015 , the government launched a plan to improve capital markets that was differentiated by the age of firms (Table 15). For firms in the start-up stage (0-3 years), the over-the-counter (OTC) market will be expanded. The OTC market began as the Free Board created in 2000 to enable SMEs that were unable to meet the listing requirements of the two securities exchanges (KOSPI and KOSDAQ) to trade their stocks and receive financing. It has been ineffective, though, due to strict regulation, a high tax on securities transactions, limited participation by KOSDAQlisted firms, and the absence of accurate corporate information (Jung, 2012). Moreover, the opening of the KONEX market in 2013 further marginalised the OTC. In 2014, the Free Board was re-organised as a two-tier market: i) KOTC, a primary market for trading unlisted stocks of blue-chip companies, has tighter screening requirements and mandatory disclosure; and ii) K-OTC BB (Korea Over-The-Counter Bulletin Board), a secondary market for all nonlisted SME stocks. Since the launch of K-OTC, the number of firms trading in the OTC market increased from 48 to 116 and daily average transaction amount increased from 90 million to 1.8 billion KRW (USD 1.6 million). The success of the K-OTC depends on its ability to act as a bridge for start-ups and early-stage SMEs trying to reach the KOSDAQ.

Table 15. The role of capital markets for each stage of the business life cycle

\begin{tabular}{|c|c|c|c|}
\hline & Start-up stage (0-3 years) & Growth stage (4-9 years) & $\begin{array}{c}\text { Mature stage (10-15 } \\
\text { years) }\end{array}$ \\
\hline \multirow{3}{*}{ Investment risk } & Very high investment risk & $\begin{array}{l}\text { Relatively high } \\
\text { investment risk }\end{array}$ & Moderate investment risk \\
\hline & - Angel investors & -Professional investors & - General investors \\
\hline & - Venture capital & - High risk takers & \\
\hline $\begin{array}{l}\text { Role \& features of } \\
\text { capital markets }\end{array}$ & Over-the-counter market & KONEX market & KOSDAQ market \\
\hline \multirow[b]{2}{*}{ 1. Features } & $\begin{array}{l}\text { - No investor protection } \\
\text { measures }\end{array}$ & $\begin{array}{l}\text { Relatively relaxed } \\
\text { investor protection }\end{array}$ & $\begin{array}{l}\text {-Strong investor protection } \\
\text { measures in place }\end{array}$ \\
\hline & $\begin{array}{l}\text { - One-on-one contract } \\
\text { solely dependent on each } \\
\text { investor's intention }\end{array}$ & $\begin{array}{l}\text { - Listing based on an } \\
\text { evaluation of a company's } \\
\text { growth potential, rather } \\
\text { than quantitative factors }\end{array}$ & $\begin{array}{l}\text { - A trading platform for } \\
\text { financially stable companies }\end{array}$ \\
\hline 2. Role & $\begin{array}{l}\text { - Facilitate secondary } \\
\text { investment in start-ups and } \\
\text { divestment of initial } \\
\text { investment for investors }\end{array}$ & $\begin{array}{l}\text { Enable divestment of } \\
\text { initial investment for } \\
\text { investors and direct } \\
\text { financing for companies }\end{array}$ & $\begin{array}{l}\text {-Raise a larger amount of } \\
\text { funds through public } \\
\text { offering }\end{array}$ \\
\hline \multirow{2}{*}{$\begin{array}{l}\text { 3. Listing } \\
\text { requirements }\end{array}$} & & $\begin{array}{l}\text {-Sign an advisory service } \\
\text { contract with a brokerage } \\
\text { firm }\end{array}$ & $\begin{array}{l}\text {-Firms with equity capital of } \\
1.5 \text { billion KRW \& net profit } \\
\text { of } 1 \text { billion KRW or sales } \\
\text { volume of } 5 \text { billion KRW }\end{array}$ \\
\hline & & $\begin{array}{l}\text {-Receive a } \quad \text { TCB } \\
\text { technology rating \& attract } \\
\text { investment by institutional } \\
\text { investors }\end{array}$ & $\begin{array}{l}\text {-Firms with promising } \\
\text { technologies are exempt } \\
\text { from listing requirements } \\
\text { (other than equity capital of } \\
1 \text { billion KRW) }\end{array}$ \\
\hline
\end{tabular}

Source: FSC (2015d).

The Korea New Exchange (KONEX) was launched in 2013 to help SMEs and venture businesses obtain direct financing from the capital market. KOSDAQ had been created in 1996 with this objective, but strict investor protection reduced the number of new companies listing on KOSDAQ from 171 in 2001 to only 21 in 2012 . To make it more effective than KOSDAQ, KONEX is similar to the Alternative Investment Market (AIM) created in 1995 in the United Kingdom and the TSX-Venture Exchange that began in Canada in 1999:

- $\quad$ KONEX substantially eased market entry and reduced the burden of information disclosures, compared to KOSDAQ, which imposes quantitative conditions. KONEX is limited to professional investors, including venture capital, institutional investors, and retail investors with a deposit of KRW 300 million (USD 262 000) or more. AIM also features short listing procedures (10 days) and low fees.

- KONEX adopted a designated advisor system in 2015 that is similar to the "nominated advisers" (nomad) in AIM. Each company must sign a contract with a securities company that acts as its designated advisor to facilitate their access to the stock exchange and strengthen investor protection. The designated advisor identifies companies to be listed, judges their qualifications, provides guidance on regulatory observance, and serves as a contact point between the company and the stock exchange. 
KONEX increased from 21 listed companies at its start in July 2013 to 89 by end-2015, while market capitalisation reached 3.7 trillion KRW (0.2\% of GDP) (Figure 23). However, it has failed to achieve the rapid growth of AIM, which had 308 companies after two years of operation and market capitalisation of $0.6 \%$ of GDP. Moreover, the average age of firms listing on the KONEX is around 12 years, similar to KOSDAQ. The government announced a strategy in 2015 to revitalise KONEX by encouraging the listing of more start-ups and attracting more venture capital. In addition to the designated advisor system to strengthen investor protection, this is to be accomplished by expanding incentives for individual investors, and easing listing requirements for SMEs by abolishing quantitative standards and replacing them with qualitative indicators. In addition, stronger incentives should be given to designated advisors to fulfil their roles (Kim, 2014).

Figure 23. Comparison of the development of KONEX and AIM

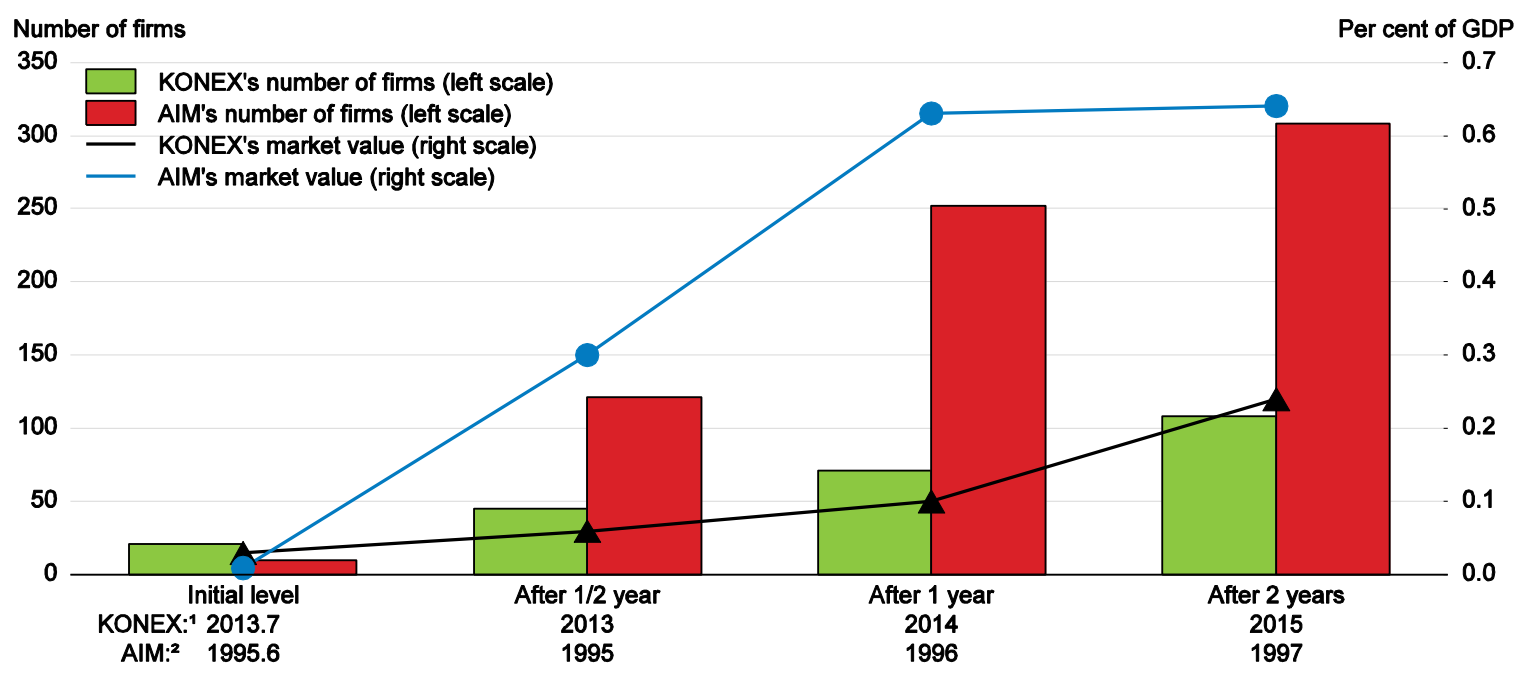

1. KONEX was created in July 2013.

2. AIM was created in June 1996.

Source: Korea Exchange (2016); London Stock Exchange Group (2015).

KOSDAQ remains the key exchange for IPOs and capital increases. The government also plans to expand listing opportunities for young firms on KOSDAQ and to foster competition between exchanges. The recent decision to separate the management of KOSDAQ and KOSPI, which is the major exchange for large firms, is intended to change the culture of KOSDAQ in favour of SMEs. As in the case of KONEX, the challenge is to carefully balance investor protection with the objective of facilitating IPOs.

The low level of M\&A activity reflects a number of factors. First, small firms rely primarily on loans, thus reducing the potential scale of the market. Second, entrepreneurs are reluctant to sell their firms, leading to a shortage of supply in the M\&A market; indeed, in Korea, M\&As have long been associated with bankruptcy proceedings. Third, active participation of buyers, such as private equity funds and strategic investors, is limited. Fourth, regulations on M\&As restrict the market. For example, for listed companies, the merger price has to be within $10 \%$ of the market value, the M\&A methods are restricted and many M\&As have to be approved by a general meeting of shareholders. The government launched a plan in 2014 to activate the M\&A market by: $i$ ) easing restrictions on investors in order to attract potential buyers; ii) providing financial support for sellers; and iii) reducing restrictions on M\&As procedures and providing tax incentives.

\section{Reducing the high level of government funding}

The venture capital market depends heavily on the government, which risks crowding out private investors. Public funds accounted for 30.3\% of venture funds in 2012, with an additional $3.7 \%$ share for 
public pension funds. The government launched a plan in 2015 to shift away from public funding of venture capital funds in favour of private funding. Previously, some private venture capital funds had to accept public financing, which resulted in government supervision and burdens on the funds. That requirement has been waived to allow the creation of funds limited to private financing, thereby enhancing their autonomy and creativity. In addition, the growth ladder fund (a fund of funds) will offer more favourable terms for sharing profits and absorbing losses to encourage private investment in venture capital funds.

\section{Expanding the role of angel investors and crowd-funding}

Business angels play an important role in private financing and mentoring firms during their initial start-up. However, following the bursting of the IT bubble in 2000, the number of angel investors fell sharply from nearly 29000 to only 619 in 2011 (Figure 24). In addition, the amount of angel investment in 2011 was only $8 \%$ of it 2000 peak. While the number of business angels has been rising since 2011 , the amount of investment has remained stagnant, amounting to only $0.002 \%$ of GDP, compared to $0.15 \%$ in the United States. The government is trying to spark greater angel investment by increasing their tax deductibility, creating an "Angel Investment Support Centre" to facilitate matchmaking between angel investors and young ventures, and the establishment of a matching fund. Finally, the government gave the green light to equity crowd-funding in January 2016, which allows entrepreneurs to raise money from the general public, although this mechanism does not always provide the guidance and networks provided by seasoned angel investors. Firms will be able to raise a maximum of 0.7 billion KRW (USD 612000 ) per year through crowd-funding. Given the problems of investor protection, limits for non-professional investors are set at 2 million KRW per company (USD 1 750) and 5 million KRW in total.

Figure 24. The amount of investment by business angels collapsed following the bursting of the IT bubble

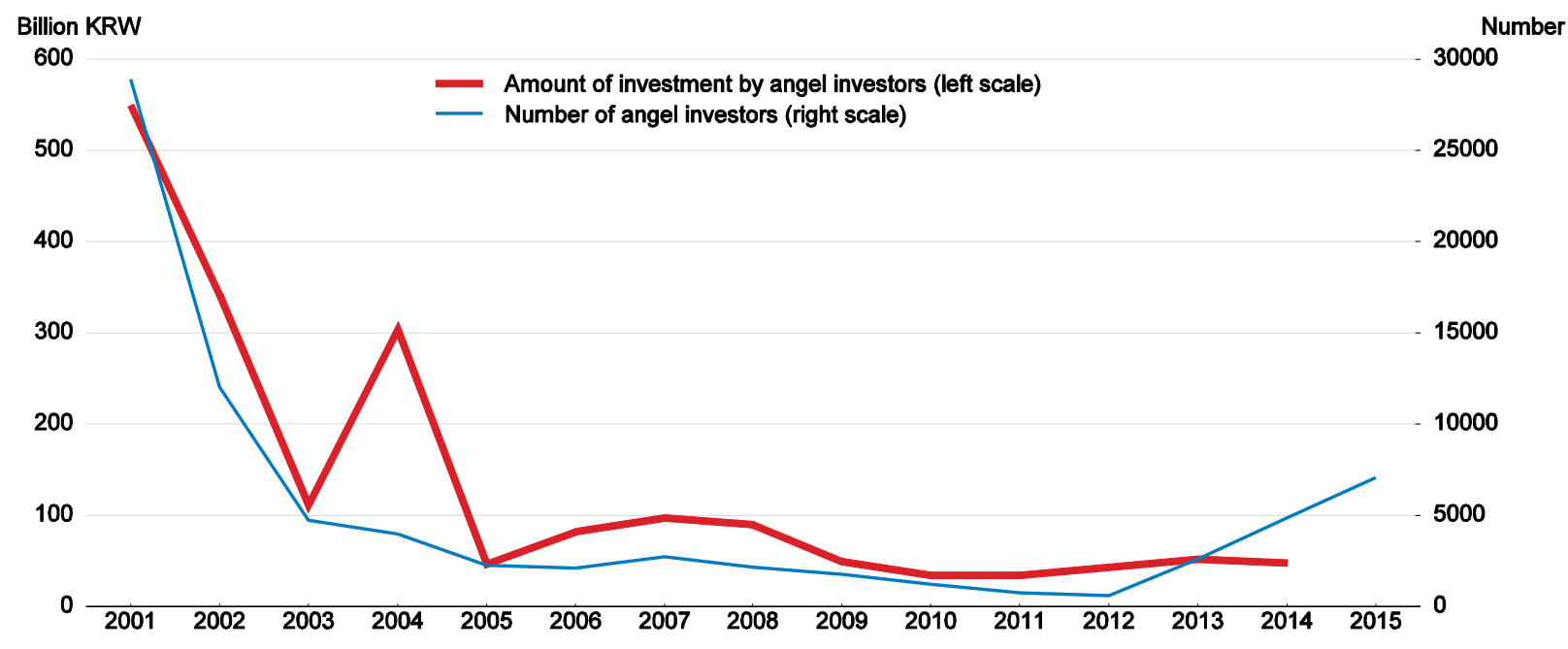

Source: Angel Investor Association; Korea Venture Capital Association; Small and Medium Business Administration. 


\section{Box 5. Summary of recommendations to increase productivity}

\section{Key recommendations}

- Use the new "cost-in, cost-out" system to reduce the regulatory burden based on accurate Regulatory Impact Assessments.

- Phase out positive-list regulations.

- Focus venture capital on start-ups by facilitating early-stage IPOs in the KOSDAQ and KONEX markets.

- Take further steps to jumpstart the M\&A market through regulatory reform.

- Relax barriers to trade and investment to help firms better connect to global innovation networks.

- Strengthen R\&D links between academia, business and government by promoting the mobility of researchers.

\section{Other recommendations}

- Lower the share of loans to SMEs that are guaranteed by the government and put time limits on their length.

- Reduce the generosity of SME support to weaken the disincentives for small firms to grow into larger enterprises, thereby increasing their productivity through economies of scale.

- Improve the skills of older workers by expanding lifelong learning, focusing on those with weak skills, and base it on the National Competency Standards to ensure its relevance to the labour market. 


\section{REFERENCES}

Ahn, S. (2015), "Entry Regulation and Industrial Performance in Korea”, 2015 KDI-World Bank International Workshop on Economic Assessment of Regulatory Reform, Korea Development Institute, Sejong.

Andrews, D. and C. Criscuolo (2013), "Knowledge-based Capital, Innovation and Resource Allocation", OECD Economics Department Working Papers, No. 1046, OECD Publishing, Paris.

Andrews, D., C. Criscuolo and C. Menon (2014), "Do Resources Flow to Innovative Firms: Cross-country Evidence from Firm-level Data”, OECD Economics Department Working Papers, No. 1127, OECD Publishing, Paris.

Andrews, D., C. Criscuolo and P. Gal (2015), "Frontier Firms, Technology Diffusion and Public Policy: Micro Evidence from OECD Countries", OECD Productivity Working Papers, No. 02, OECD Publishing, Paris.

Baek, D. and W. Joo (2014a), "Status of Productivity and Implications for the Service Industry", VIP Report 14-15, Vol. 566, Hyundai Research Institute, Seoul (in Korean).

Baek, D. and W. Joo (2014b), "International Comparison of Productivity and Implications for the Service Industry", Weekly Economic Review 14-13, Vol. 584, Hyundai Research Institute, Seoul (in Korean).

Bank of Korea (2014), “Analysis of Recent Financial Stability Issues”, Financial Stability Report (October), Seoul.

Chang, W., Y. Yang and S. Woo (2014), “A Study on the Enhancement of Policies for Small and Medium-sized Enterprises in Korea (II)”, Research Monograph, Korea Development Institute, Sejong, (in Korean).

Chang, W. (2015), "Reforming SME Policy in Korea: Diagnosis and Prescription”, Korea Institute of Public Finance SME Policy Seminar (19 November), Korea Development Institute, Sejong.

Chang, W. (2016), “Is Korea's Public Funding for SMEs Achieving Its Intended Goals?” KDI Focus (February), Korea Development Institute, Sejong.

Cho, G., H. Kang, J. Kim, C. Shon, and M. Kim (2014), Report on the Korean Innovation Survey 2014: Manufacturing and Service Sector, Science and Technology Policy Institute, Sejong (in Korean).

Cho, Y. and S. Kim (2013), "Zero Base Review of Small Business Regulations and Suggestions for Improvement", KOSBI Basic Research Report, No. 13-20, 13-21, Korea Small Business Institute, Seoul (in Korean).

Choe, H., H. Chun and Y. Lee (2014), "A Study of the Effects of Entry and Exit on Productivity Growth in the Personal Service Sector”, KIET Research Report, Vol. 2014-698, Korea Institute for Industrial Economics and Trade, Sejong (in Korean).

Colombo, M., L. Grilli and S. Murtinu (2011), "R\&D Subsidies and the Performance of High-Tech Start-Ups", Economics Letters, Vol. 112(1).

Financial Services Commission (2013), "Results of the SME Financing Situation Committee", Press Release (7 June), Seoul (in Korean).

Financial Services Commission (2015a), "Building A New Guarantee System for SMEs”, Press Release (4 November), Seoul (in Korean).

Financial Services Commission (2015b), “Key Policy Direction for Financial Regulatory Reform”, Press Release (17 March), Seoul (in Korean).

Financial Services Commission (2015c), "Plans to Activate Investment of Small and Medium Venture Companies to Support the Development of an Autonomous Venture Ecosystem", Press Release (17 July), Seoul (in Korean).

Financial Services Commission (2015d), "Policy Directions for Capital Market Reform: Measures to Vitalise the KONEX, OTC Trading of Unlisted Stocks and the Derivative Market", Press Release (23 April), Seoul (in Korean).

Financial Supervisory Service (2016), Press Release (26 January), Seoul (in Korean).

Global Entrepreneurship Monitor (2012), Global Entrepreneurship Monitor Country Profile for South Korea, http://www.gemconsortium.org/country-profile/125. 
Han, S. and S. Inn (2008), "The Effect of Deregulation on Economic Growth", Bank of Korea Monthly Bulletin (September), Seoul (in Korean).

Industrial Bank of Korea (IBK) (2015), "2015 Research on the Actual Condition for SME Financing in International Comparison", Seoul (in Korean).

Jaumotte, F. and N. Pain (2005), "From Ideas to Development: The Determinants of R\&D and Patenting", OECD Economics Department Working Papers, No. 457, OECD Publishing, Paris.

Jones, R. (2009), "Boosting Productivity in Korea's Service Sector", OECD Economic Department Working Papers, No. 673, OECD Publishing, Paris.

Jones, R. (2013), "Education Reform in Korea”, OECD Economic Department Working Papers, No. 1067, OECD Publishing, Paris.

Jones, R. and M. Kim (2014), "Promoting the Financing of SMEs and Start-ups in Korea", OECD Economics Department Working Papers, No. 1162, OECD Publishing, Paris.

Jones, R. and K. Fukawa (2016), "Labour market reforms in Korea to promote inclusive growth", OECD Economics Department Working Papers, No. 1325, OECD Publishing, Paris.

Jung Y. (2012), "Measures to Connect Venture Capital and Capital Markets in Order to Develop Small and MediumSized Venture Companies", Bulls Review, Vol. 524, Korea Financial Investment Association, Seoul (in Korean).

Kim, Y. (2014), "Policy Directions for the Long-term Development of the KONEX Market on the Occasion of its First Anniversary“, This Week's Forum, Vol.23, No.29, Korea Institute of Finance, Seoul (in Korean).

Kim, G. (2015), "The Design of Technology Finance Requires Radical Surgery”, KOSBI SME Focus, Vol.15-16, Korea Small Business Institute, Seoul (in Korean).

Kleer, R. (2010), “Government R\&D Subsidies as a Signal for Private Investors”, Research Policy, Vol. 39, Issue 10.

Koh, Y., S. Kim, C. Kim, Y. Lee, J. Kim, S. Lee and Y. Kim (2010), "Social Policy", in The Korean Economy: Six Decades of Growth and Development, edited by I. SaKong and Y. Koh, Korea Development Institute, Sejong.

Koo, J., Y. Kim and S. Lee (2015), “A Study of Current SME Financing in Korea and Its Relationship with SMEs' Financing Condition”, KIF Policy Research Paper, 2015-02, Korea Institute of Finance, Seoul (in Korean).

Korea Development Institute, Korea Small Business Institute and Research Institute for the Assessment of Economic and Social Policies (2011), In-Depth Study on Fiscal Programmes 2010: The SME Sector, Sejong (in Korean).

Korea Productivity Centre (2014), International Comparison of Total Factor Productivity, Seoul (in Korean).

Korea Exchange (2015), KRX2016 Fact Book, Seoul.

Koske, I., I.Wanner, R. Bitetti and O. Barbiero (2015), "The 2013 Update of the OECD Product Market Regulation Indicators: Policy Insights for OECD and non-OECD countries", OECD Economics Department Working Papers, No. 1200, OECD Publishing, Paris.

Lee, B. (2014), "Productivity Effects of the Entry and Exit of Firms and Reform of Entry Regulation", Policy Study, 2014-20, Korea Economic Research Institute, Seoul (in Korean).

Lee, M. (2015), Creative Economy@ Korea, Korea Creative Economy Research Network, Seoul.

Lee, M. (2016), "Creative Economy in Korea”, Mimeo, Korea Creative Economy Research Network, Seoul.

Lim, W. (2015), “Cost-in, Cost-out: A Catalyst for Evidence-Based Regulatory Reform in Korea?” Mimeo, Korea Development Institute, Sejong.

London Stock Exchange Group (2015), AIM Factsheet, London.

Martin, J. and S. Scarpetta (2012), "Setting it Right: Employment Protection, Labour Reallocation and Productivity", De Economist, Vol. 160, Issue 2.

Ministry of Strategy and Finance (2014), "Measures to Stimulate Investment: Fostering Promising Service Industries”, Press Release (12 August), Sejong. 
Nam J., J. Kim, M. Noh and Y. Kim (2015), "Performance Analysis of Credit Guarantees and Adequacy Reviews of Major Projects", Korea Credit Guarantee Fund, Seoul (in Korean).

Office for Government Policy Coordination (2013), "To Reduce the Threshold of Corporate Investment Through the Expansion of a Negative Regulatory Scheme", Press Release (22 August), Sejong (in Korean).

OECD (2016a), Financing SMEs and Entrepreneurs 2016: An OECD Scoreboard, OECD Publishing, Paris. http://www.oecd-ilibrary.org/content/book/fin_sme ent-2016-en

OECD (2016b), OECD Economic Surveys: Korea, OECD Publishing, Paris. http://www.oecd.org/eco/surveys/economic-survey-korea.htm

OECD (2016c), OECD Services Trade Restrictiveness Index (STRI): Korea. http://www.oecd.org/tad/services-trade/STRI_KOR.pdf

OECD (2015a), "Korea Policy Priorities for a Dynamic, Inclusive and Creative Economy", OECD Better Policies Series, OECD Publishing, Paris.

https://www.oecd.org/korea/korea-policy-priorities-for-a-dynamic-inclusive-and-creative-economy-EN.pdf

OECD (2015b), OECD Digital Economy Outlook 2015, OECD Publishing, Paris. http://www.oecd-ilibrary.org/science-and-technology/oecd-digital-economy-outlook-2015_9789264232440-en

OECD (2015c), OECD Regulatory Policy Outlook, OECD Publishing, Paris. http://www.oecd-ilibrary.org/governance/oecd-regulatory-policy-outlook-2015 9789264238770-en

OECD (2015d), OECD Science, Technology and Industry Scoreboard, OECD Publishing, Paris. http://www.oecd-ilibrary.org/science-and-technology/oecd-science-technology-and-industry-scoreboard2015_sti_scoreboard-2015-en

OECD (2015e), OECD Skills Strategy Diagnostic Report: Korea, OECD Publishing, Paris. http://www.oecd.org/skills/nationalskillsstrategies/Diagnostic-report-Korea.pdf

OECD (2015f), The Future of Productivity, OECD Publishing, Paris. http://www.oecd-ilibrary.org/economics/the-future-of-productivity_9789264248533-en

OECD (2014a), OECD Surveys of Innovation Policies: Industry and Technology Policies in Korea, OECD Publishing, Paris. http://www.oecdilibrary.org/docserver/download/9214081e.pdf?expires=1470934053\&id=id\&accname=ocid $84004878 \&$ check sum=2B966FA3E04A58AEC96588F6560B1E75

OECD (2014b), OECD Economic Surveys: Korea, OECD Publishing, Paris. http://www.oecd-ilibrary.org/economics/oecd-economic-surveys-korea-2014_eco surveys-kor-2014-en

OECD (2014c), Science, Technology and Industry Outlook 2014, OECD Publishing, Paris. http://www.oecd-ilibrary.org/science-and-technology/oecd-science-technology-and-industry-outlook2014_sti_outlook-2014-en

OECD (2013a), Entrepreneurship at a Glance 2013, OECD Publishing, Paris. http://www.oecd-ilibrary.org/industry-and-services/entrepreneurship-at-a-glance-2013_entrepreneur_aag2013-en

OECD (2013b), OECD Science, Technology and Industry Scoreboard 2013: Innovation for Growth, OECD Publishing, Paris.

http://www.oecd-ilibrary.org/science-and-technology/oecd-science-technology-and-industry-scoreboard2013_sti_scoreboard-2013-en

OECD (2013c), OECD Skills Outlook 2013: First Results from the Survey of Adult Skills, OECD Publishing, Paris. http://www.oecd-ilibrary.org/education/oecd-skills-outlook-2013 9789264204256-enOECD (2007), OECD Reviews of Regulatory Reform: Korea, OECD Publishing, Paris. http://www.oecd-ilibrary.org/governance/oecd-reviews-of-regulatory-reform 9789264037717-ko

OECD (2012), OECD Economic Surveys: Korea, OECD Publishing, Paris. http://www.oecd-ilibrary.org/economics/oecd-economic-surveys-korea-2012_eco_surveys-kor-2012-en 
OECD (2010), Making Reform Happen: Lessons from OECD Countries, OECD Publishing, Paris. http://www.oecd-ilibrary.org/economics/making-reform-happen_9789264086296-en

OECD (2009), OECD Reviews of Tertiary Education: Korea, OECD Publishing, Paris. http://www.oecd-ilibrary.org/education/oecd-reviews-of-tertiary-education-korea-2009_9789264049055-en

Park, J. et al. (2014), "The Effects of Korea's Service Industry Reform and Its Direction", KIET Research Report, 2014-702, Korea Institute for Industrial Economics and Trade, Sejong (in Korean).

Park, J. (2015a), "The Performance of Regulatory Reforms in Service Industries and Its Future", Journal of Regulation Studies, Vol. 24, Korea Economic Research Institute, Seoul (in Korean).

Park, J. (2015b), "The Tasks of Regulatory Reform in Service Industries to Revitalise the Economy", presented at Korea Economic Research Institute's seminar, "Regulatory Reform and Future Challenges for Park Geunhye's Government", Seoul (9 July) (in Korean).

Park, S., Lee, J. and S. Kim (2015), Three Grand Strategies for National Re-Creation, edited by S. Kang, Hansun Foundation, Seoul (in Korean).

Shin, S. (2015), “Analysis and Implications of Marginal Companies", KOSBI SME Focus, Vol.15-14, Korea Small Business Institute, Seoul (in Korean).

Sohn, S. and D. Kim (2013), Tasks for the Development of SME Financing, Korea Institute of Finance, Seoul.

Westmore, B. (2013), "R\&D, Patenting and Growth: The Role of Public Policy", OECD Economics Department Working Papers, No. 1047, OECD Publishing, Paris.

World Economic Forum (2015), Global Competitiveness Report 2015-16, http://www3.weforum.org/docs/gcr/20152016/Global_Competitiveness_Report_2015-2016.pdf. 